\title{
ESTRUTURAS FINITAS DE REPETIÇÃO VERBAL EM PORTUGUÊS BRASILEIRO
}

Versão Original

Dissertação apresentada ao Programa de Pós graduação em Semiótica e Linguística Geral, da Faculdade de Filosofia, Letras e Ciências Humanas, da Universidade de São Paulo como parte dos requisitos para a obtenção do título de Mestre em Linguística.

Orientador: Prof. Dr. Jairo Morais Nunes

São Paulo 
Autorizo a reprodução e divulgação total ou parcial deste trabalho, por qualquer meio convencional ou eletrônico, para fins de estudo e pesquisa, desde que citada a fonte.

Catalogação na Publicação

Serviço de Biblioteca e Documentação

Faculdade de Filosofia, Letras e Ciências Humanas da Universidade de São Paulo

S231e

Santos, Leticia Evelyn Leite

Estruturas finitas de repetição verbal em português brasileiro / Leticia Evelyn Leite Santos ; orientador Jairo Morais Nunes. - São Paulo, 2018. $100 \mathrm{f}$.

Dissertação (Mestrado) - Faculdade de Filosofia, Letras e Ciências Humanas da Universidade de São Paulo. Departamento de Linguística. Área de concentração: Semiótica e Lingüística Geral.

1. Linguística. 2. Linguística Gerativa. 3. Sintaxe formal. I. Nunes, Jairo Morais, orient. II. Título. 
SANTOS, L. E. L. Estruturas finitas de repetição verbal em português brasileiro.

Dissertação apresentada à Faculdade de Filosofia, Letras e Ciências Humanas da Universidade de São Paulo para obtenção do título de Mestre em Linguística.

Aprovado em:

Banca Examinadora

Prof. Dr. Instituição:

Julgamento:

Assinatura:

Prof. Dr. Instituição:

Julgamento: Assinatura:

Prof. Dr. Instituição:

Julgamento: Assinatura: 
“Sem sintaxe não há emoção duradoura. A imortalidade é uma função dos gramáticos”.

Fernando Pessoa, Livro do Desassossego 
Em memória de Zira, a maior amiga e companheira que tive nessa vida 


\section{AGRADECIMENTOS}

Esta dissertação só foi possível graças à ajuda de inúmeros fatores e pessoas às quais merecem o devido agradecimento.

Agradeço à CAPES pelo apoio financeiro em forma de bolsa de Mestrado sem o qual esta pesquisa não seria possível.

Agradeço imensamente ao meu orientador Jairo Morais Nunes pela orientação desde a Iniciação Científica, pela paciência, pelo incentivo, pelas recomendações e pelo apoio nas questões burocráticas (e nas surpresas que aconteciam). Seu comprometimento com a ciência e com os orientandos são inspiradores. Essa dissertação nunca teria sido finalizada sem suas observações e comentários preciosos.

Agradeço à minha família pela paciência e compreensão nesse tempo em que estive escrevendo e estudando. E é, claro, não posso deixar de incluir Barruan, Jade e Tatá pela companhia nos dias de estudo e por me lembrarem que existe vida além dos estudos.

Agradeço a Guilherme Morimura pelo apoio e companheirismo, por me aguentar falando dessa pesquisa por mais de dois anos, por ser meu testador de gramaticalidade, por me ajudar com os pôsteres dos congressos, por revisar o que eu escrevia e por sempre ouvir meus dilemas. Estes dois anos seriam muito difíceis se eu não tivesse você ao meu lado.

Agradeço aos integrantes do grupo de estudos Minimalismo e Teoria da Gramática, Claudia Coelho, Rosiani Bueno, Rafael Camacho e Janayna Carvalho, pelas ajudas infinitas e pela amizade que criamos. Em especial, agradeço a Janayna Carvalho pelos comentários desde que esta pesquisa era um projeto de 15 folhas.

Agradeço às professoras Ana Scher e Esmeralda Negrão pelos comentários desde a arguição do projeto, comentários os quais me deram luz em vários momentos. Agradeço também a Andrés Saab, Ana Maria Martins e Renato Lacerda pelas trocas de e-mails e comentários iluminadores.

Agradeço a Luiz Fernando Ferreira, que me auxiliou muitas vezes nas questões burocráticas que eu não conhecia, por ser um braço direito nas comissões em que participamos e pela amizade. 
SANTOS, L. E. L. Estruturas finitas de repetição verbal em português brasileiro. Dissertação (Mestrado). Faculdade de Filosofia, Letras e Ciências Humanas, Universidade de São Paulo, 2018.

O objetivo desta dissertação é descrever o comportamento de estruturas com repetição verbal em português brasileiro que apresentam características específicas diferentes de outras construções com repetição verbal já estudas no português brasileiro (Bastos 2001/ Bastos-Gee 2009) e no português europeu (Martins 2007). As estruturas em questão são iniciadas com que, sendo que em cada uma delas o constituinte encabeçado por que aparece em posições diferentes na sentença: quando o que está no primeiro bloco, nomeio a estrutura de que-reportativo; quando o que está no segundo bloco, nomeio a estrutura de que-adversativo. Essas construções apresentam similaridades, como a necessidade dos constituintes verbais serem idênticos, mas também apresentam muitas diferenças entre si além da posição do que: ter necessidade de repetir um antecedente discursivo obrigatoriamente, que só ocorre com que-reportativo, e a presença de uma sentença coordenada adversativa implícita, o efeito-mas (Bastos 2001/Bastos-Gee 2009), que também só ocorre com que-reportativo. Através da comparação com outras estruturas de repetição verbal já estudadas no português, mostro que as construções analisadas nesta dissertação possuem comportamentos diferenciados e envolvem tópicos diferentes, a saber, a estrutura com que-reportativo envolve tópico conversacional, enquanto a estrutura com que-adversativo envolve tópico contrastivo.

Palavras-chave: Repetição verbal; Tópico, Efeito-mas; Português brasileiro. 
SANTOS, L. E. L. Finite structures with verbal repetition in Brazilian Portuguese. Dissertação (Mestrado). Faculdade de Filosofia, Letras e Ciências Humanas da Universidade de São Paulo, 2018.

The goal of this dissertation is to describe the behavior of finite structures with verbal repetition in Brazilian Portuguese, which present different specific characteristics from other verbal repetition constructions previously studied in Brazilian Portuguese (Bastos 2001/ Bastos-Gee 2009) and in European Portuguese (Martins 2007). The structures in question start with que 'that', but the constituents headed by que occupy different positions in each structure: when que is in the first block of the sentence, I call the structure reportative-que; when que is in the second block of the sentence, I call the structure adversative-que. These structures present similarities, such as the requirement of identical verbal constituents, but also exhibit many differences besides the position where que appears: the requirement to repeat the previous discourse and the presence of an implicit adversative clause - the but-effect (Bastos 2001/ Bastos-Gee 2009) -, for instance, only happens with reportative-que. Through the comparison with other verbal repetition structures already studied in Portuguese, I demonstrate the structures analyzed in this dissertation have a differentiated behavior. I also demonstrate that they are composed by different topics, namely, reportative-que has a conversational topic, while adversative-que has a contrastive topic.

Key-words: Verbal repetition; Topic; But-effect; Brazilian Portuguese. 


\section{Sumário}

Seções

Página

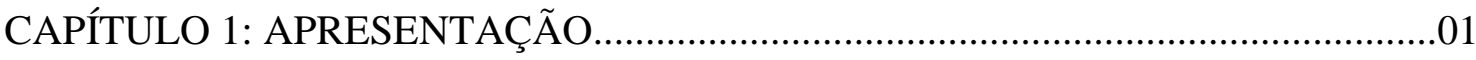

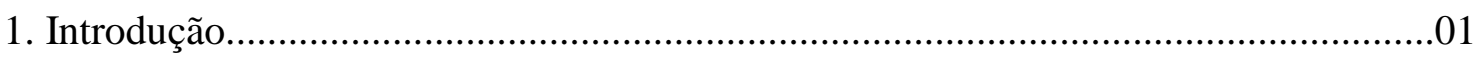

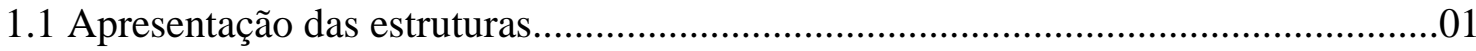

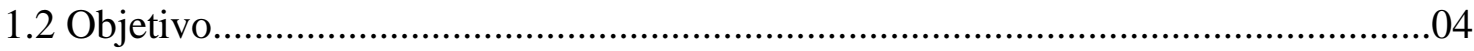

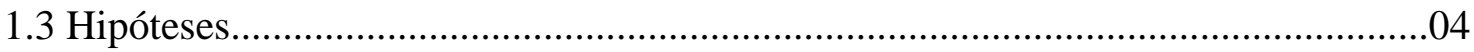

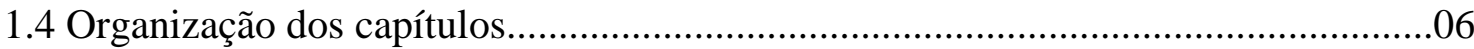

CAPÍTULO 2: $Q U E$-REPORTATIVO, $Q U E$-ADVERSATIVO E

OUTRAS ESTRUTURAS COM REPETIÇÕES VERBAIS...................07

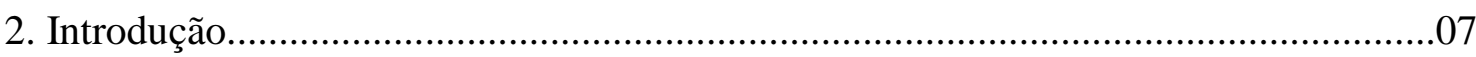

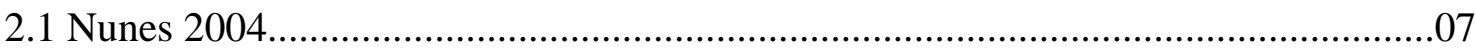

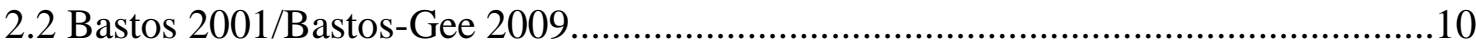

2.2.1 Contrastando com que-reportativo e que-adversativo................................16

2.2.1.1 Repetição verbal idêntica dentro das estruturas.......................................16

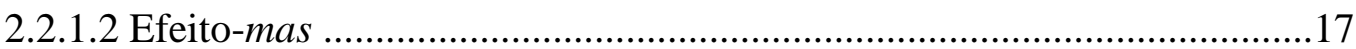

2.2.1.3 Cancelamento do efeito-mas.................................................................18

2.2.1.4 Efeito-mas com outros itens lexicais....................................................20

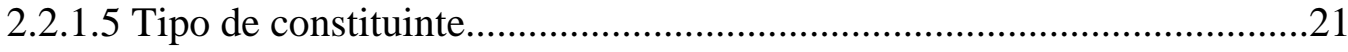

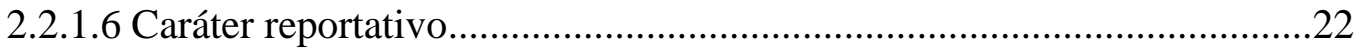

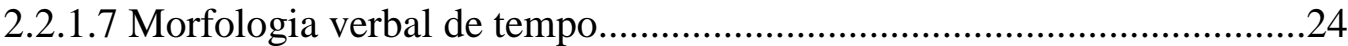

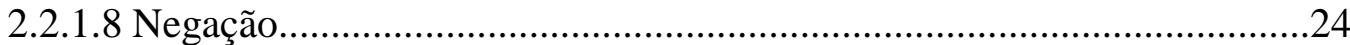

2.2.1.9 Repetição com constituintes morfologicamente complexos....................26

2.2.1.10 Geração na base ou por movimento.....................................................27

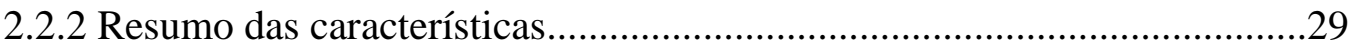

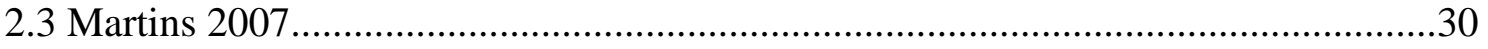

2.3.1 Contrastando com que-reportativo e que-adversativo...............................32

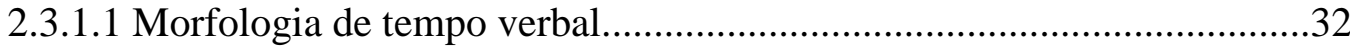

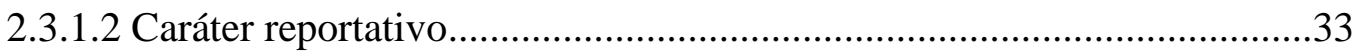

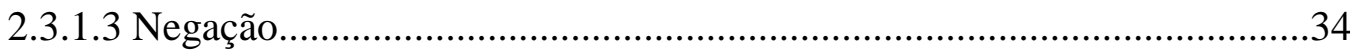

2.3.1.4 Repetição com constituintes morfologicamente complexos....................35

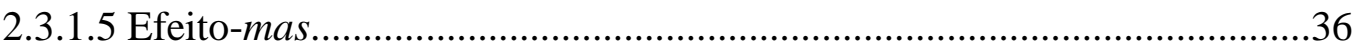

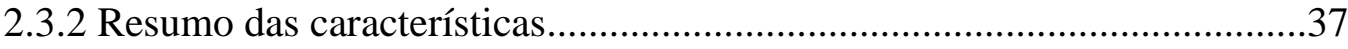




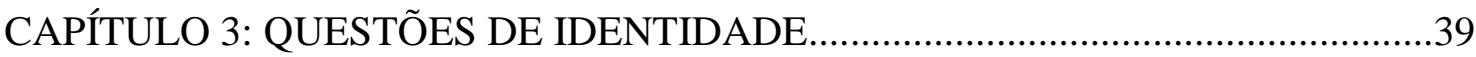

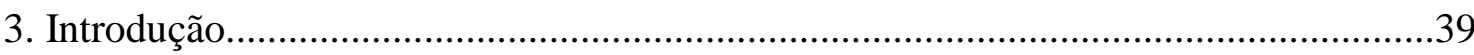

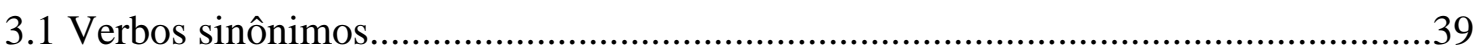

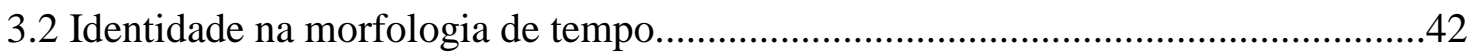

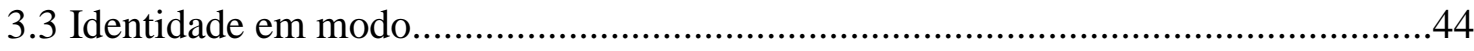

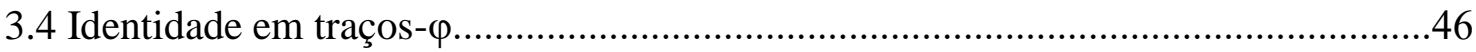

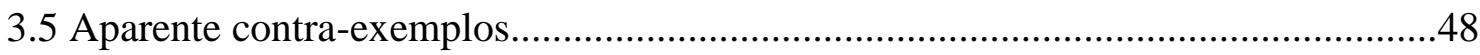

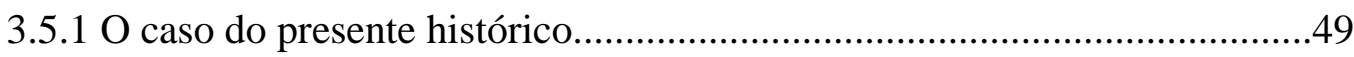

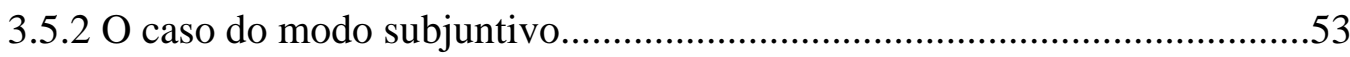

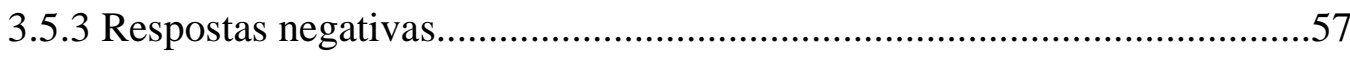

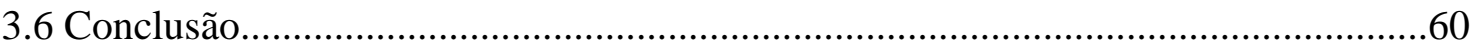

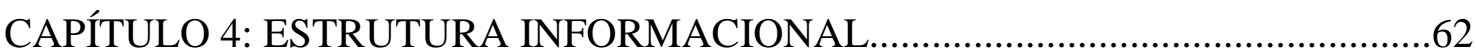

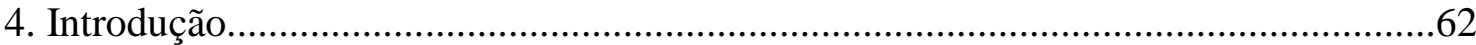

4.1 Características e definições de foco e tópico...........................................................62

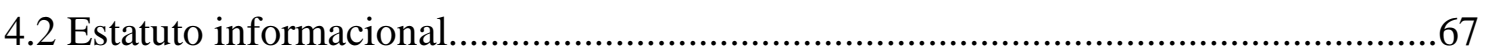

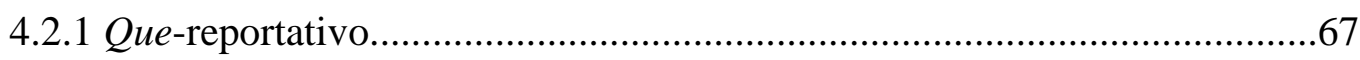

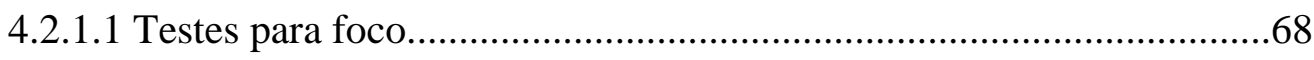

4.2.1.2 Características de tópico...................................................................70

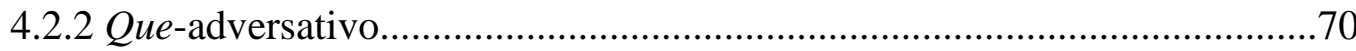

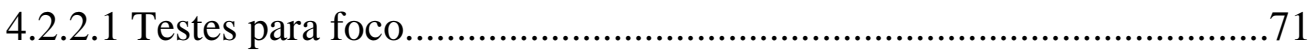

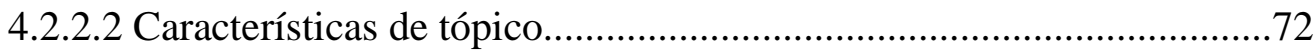

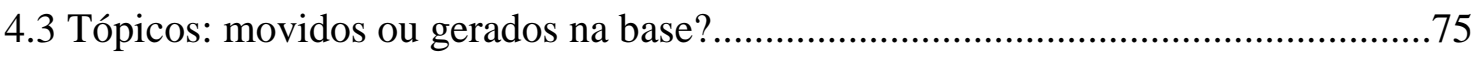

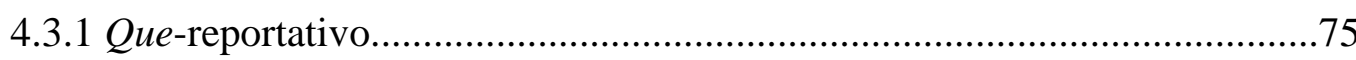

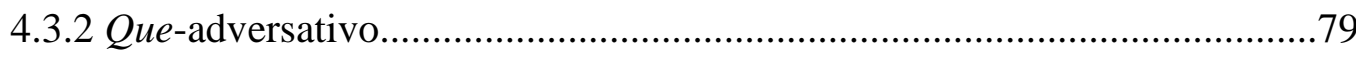

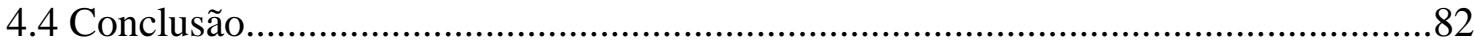

CAPÍTULO 5: EFEITO-MAS NAS ESTRUTURAS COM QUE-

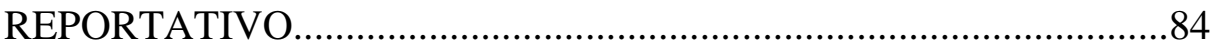

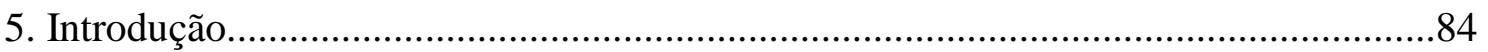

5.1 Efeito-mas em Bastos (2001)/ Bastos-Gee (2009) e Vicente (2007).......................84

5.2 Cancelamento do efeito-mas nas construções com que-reportativo...........................87

5.3 A causa do cancelamento do efeito-mas nas estruturas com que-reportativo...........89

5.4 A possibilidade de outros itens lexicais com efeito-mas.......................................93 


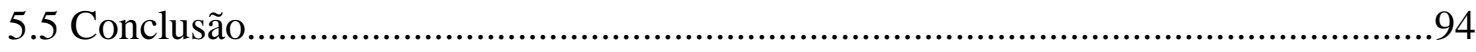

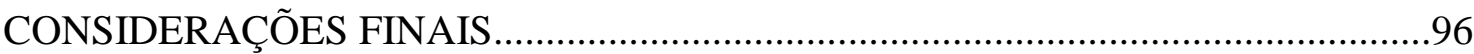

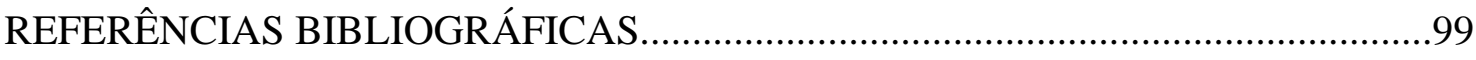




\section{CAPÍTULO 1: APRESENTAÇÃO}

\section{Introdução}

Neste capítulo apresento as estruturas que serão analisadas nesta dissertação, nomeadas estruturas com que-reportativo e que-adversativo, mostrando as principais diferenças entre elas. Também são apresentados o objetivo desta pesquisa, as hipóteses acerca dessas estruturas e a organização desta dissertação.

\subsection{Apresentação das estruturas}

Existem duas estruturas com reduplicação verbal em português brasileiro iniciadas com que, sendo que em cada uma delas o constituinte encabeçado por que aparece em posições diferentes na sentença:

(1) QC ${ }^{1}$ : O João lavou o carro?

$\mathrm{R}$ : [Que ele lavou o carro], ele lavou (mas...) $)^{2}$

(2) QC: O João tomou o remédio para gripe?

R: Não, mas [que ele deveria tomar o remédio], ele deveria.

Em (1) a estrutura com que, que vou chamar de que-reportativo, é o primeiro termo da sentença, enquanto que em (2), a estrutura com que, que vou chamar de queadversativo, faz parte do segundo termo. Essas estruturas diferem não apenas em termos de posição, mas também pela necessidade de repetir um antecedente discursivo obrigatoriamente, que só ocorre com que-reportativo, como mostram (3) e (4).

(3) Que-reportativo

a. QC: Você vai pedir esse hambúrguer?

R: Que eu vou pedir, eu vou (mas...)

b. QC: Você vai pedir esse hambúrguer?

\footnotetext{
${ }^{1} \mathrm{QC}=$ questão contextualizadora.

${ }^{2}$ Negrito será utilizado para chamar atenção aos constituintes e/ou sentenças relevantes para os fenômenos discutidos.
} 
R: \#Que eu como salada, eu como em casa (mas...).

(4) Que-adversativo

a. QC: Você vai pedir esse hambúrguer?

R: Sim, mas que eu não deveria pedir, não deveria.

b. QC: Você vai pedir esse hambúrguer?

R: Sim, mas que eu deveria comer salada, eu deveria.

Além disso, as duas construções se diferenciam pela presença de uma sentença coordenada adversativa implícita (seguindo Bastos 2001/ Bastos-Gee 2009, chamarei essa sentença de efeito-mas) com que-reportativo, mas não com que-adversativo:

(5) a. Que-reportativo

QC: O Pedro vende verduras mais barato?

R: Que ele vende mais barato, ele vende (mas...)

b. Que-adversativo

QC: O Pedro vende verduras mais barato?

R: Não, mas que ele poderia vender, ele poderia.

Curiosamente, o efeito-mas mostrado em (5) para as construções com quereportativo deixa de ser obrigatório quando acrescentamos um verbo epistêmico com sujeito em primeira pessoa do singular, como vemos no contraste entre (6) e (7) abaixo.

(6) a. QC: O João comeu o bolo?

R: Que ele comeu o bolo, eu acho que ele comeu.

b. QC: A Maria leu o livro que eu recomendei?

R: Que ela leu o livro, eu acredito que ela leu.

c. QC: O Pedro comeu a torta que eu fiz?

R: Que ele comeu a torta, eu penso que ele comeu.

(7) a. QC: O João comeu o bolo?

R: Que ele comeu o bolo, a Maria acha que ele comeu (mas...)

b. QC: A Maria leu o livro que eu recomendei? 
R: Que ela leu o livro, o Pedro acredita que ela leu (mas...)

c. QC: O Pedro comeu a torta que eu fiz?

R: Que ele comeu a torta, a Maria pensa que ele comeu (mas...)

As estruturas com que-reportativo e que-adversativo possuem diferenças em relação a outras estruturas de repetição verbal já estudadas no português, como as estruturas de topicalização de infinitivos no português brasileiro (Bastos 2001, 2009), e as estruturas enfáticas do português europeu (Martins 2007). Por exemplo, as estruturas com que-reportativo e que-adversativo permitem negação e mais de um verbo na repetição, mas não as estruturas de topicalização de infinitivos e as estruturas enfáticas, como mostram os contrastes em (8)-(10) abaixo para negação e em (11)-(13) para mais de um verbo na repetição.

(8) a. Que-reportativo

QC: Não choveu por aqui à tarde?

R: Que não choveu, não choveu (mas o tempo estava feio)

b. Que-adversativo

QC: Você vai à festa?

R: Sim, mas que eu não queria ir, não queria.

(9) Topicalização de infinitivos em PB

a. Temperar, o cozinheiro não temperou o peixe

a'. *Não temperar, o cozinheiro não temperou o peixe.

b. Temperar aquele peixe, o cozinheiro não temperou (mas...)

b'. *Não temperar aquele peixe, o cozinheiro não temperou (mas...)

c. Temperar peixe, o cozinheiro não tempera nos fins de semana.

c'. *Não temperar peixe, o cozinheiro não tempera nos fins de semana.

(10) Reduplicação enfática em PE (Martins 2007, p. 85, adaptado)

QC: O João ganhou a loteria.

a. O João não ganhou a loteria, ganhou.

b. *O João não ganhou a loteria, não ganhou.

c. * O João ganhou a loteria, não ganhou. 
(11) a. Que-reportativo

QC: O João não devia tomar o remédio de gripe?

R: Que ele devia tomar o remédio, ele devia tomar (mas ele não aceita).

b. Que-adversativo

QC: A Maria tomou os remédios na hora certa?

R: Não, mas que ela devia tomar, ele devia tomar.

(12) Topicalização de infinitivos em PB

a. Temperar, o cozinheiro devia temperar o peixe.

a'*Dever temperar, o cozinheiro devia temperar o peixe.

b. Temperar aquele peixe, o cozinheiro devia temperar (mas...)

b' *Dever temperar aquele peixe, o cozinheiro devia temperar (mas...)

c. Temperar peixe, o cozinheiro devia temperar.

c'*Dever temperar peixe, o cozinheiro devia temperar.

(13) Reduplicação enfática em PE (Martins 2007: 89)

A: Ele não pode sair de casa.

B: Ele pode sair de casa, pode.

B': *Ele pode sair de casa, pode sair.

As diferenças mostradas em (8)-(13) acima sugerem que as estruturas sintáticas das construções com que-reportativo e que-adversativo não podem ser as mesmas das outras construções com repetição verbal. Assim, uma análise para as estruturas com que-reportativo e que-adversativo se faz necessária, a fim de dar conta das características dessas estruturas.

\subsection{Objetivo}

O objetivo desta pesquisa é descrever e investigar o funcionamento das construções com que-reportativo e que-adversativo, analisando-as quanto a seus aspectos sintáticos e informacionais.

\subsection{Hipóteses}


1) Funcionamento das estruturas analisadas em comparação com outras estruturas de repetição verbal do português

Para um mapeamento inicial das estruturas analisadas nesta dissertação, foi feito uma comparação com estruturas de topicalização de infinitivos analisadas por Bastos (2001)/ Bastos-Gee (2009), e com estruturas de reduplicação enfática do português europeu analisadas por Martins (2007). A hipótese é que, apesar de serem aparentemente parecidas com as construções de repetição verbal citadas anteriormente, as estruturas com que-reportativo e que-adversativo possuem estruturas diferentes.

2) Questões de identidade

Há dois pontos a serem analisados nas questões de identidade: identidade entre contexto e as estruturas com que-reportativo e que-adversativo e identidade entre as instâncias verbais dessas estruturas.

Em relação à identidade com o contexto, a hipótese é que, por causa do caráter reportativo, as estruturas com que-reportativo são mais sensíveis à forma morfossintática dos verbos do que as estruturas com que-adversativo. Já identidade entre as instâncias verbais dentro das estruturas, a hipótese é que a repetição verbal idêntica é característica da estrutura e não pode ser alterada.

3) Estatuto informacional dos blocos das estruturas

As estruturas com que-reportativo são compostas por dois blocos: um bloco iniciado por que e um bloco envolvendo uma sentença. A hipótese é que o primeiro bloco das estruturas com que-reportativo é um tópico conversacional devido a suas características de estar mais à esquerda, ser separado por entoação de vírgula e apresentar informação velha (Rizzi 1997). Serão apresentados testes para foco (Zubizareta 1998) que apoiam a hipótese, já que essas estruturas não apresentam foco.

As estruturas com que-adversativo são compostas por três blocos: um bloco que responde à questão contextualizadora ou ao contexto, um bloco iniciado por mas que e um bloco envolvendo uma sentença. A hipótese é que o segundo bloco é um tópico contrastivo, pois apresenta duas características de tópico conversacional, como estar mais à direita e ser separado por entoação de vírgula, mas apresenta informação nova. 
Porém, a análise irá mostrar que essa informação nova é limitada, classificando esse tópico como contrastivo (Büring 2000, Lee 2003).

4) Falta de obrigatoriedade do efeito-mas nas construções com que-reportativo em sentenças encaixadas de verbo epistêmico com sujeito em primeira pessoa do singular.

A hipótese é que o efeito-mas deixa de ser obrigatório quando inserimos uma sentença encaixada de verbo epistêmico com sujeito em primeira pessoa do singular porque, em consonância com a proposta de Bastos (2001)/ Bastos-Gee (2009), o efeitomas está relacionado com a quantidade de informação que o falante transmite (Máxima de Quantidade de Grice 1975).

\subsection{Organização dos capítulos}

Esta dissertação está organizada da seguinte forma: no capítulo 2, apresento o quadro teórico que será usado para a comparação entre estruturas com que-reportativo e $q u e$-adversativo e outras estruturas com repetição verbal já estudadas do português, além de apresentar a comparação entre essas estruturas; no capítulo 3, analiso as propriedades das estruturas com que-reportativo e que-adversativo a respeito de questões de identidade; no capítulo 4, apresento o quadro teórico sobre tópico e foco (Rizzi 1997, Zubizarreta 1998, Büring 2000, Lee 2003, Bianchi \& Frascarelli 2010) e analiso as estruturas com que-reportativo e que-adversativo segundo esse quadro; no capítulo 5, apresento as análises de Bastos (2001)/ Bastos-Gee (2009) e Vicente (2007) para explicar o cancelamento do efeito-mas e depois analiso o cancelamento nas estruturas com que-reportativo. Por fim, apresento as considerações finais. 


\section{CAPÍTULO 2: $Q U E$-REPORTATIVO, $Q U E$-ADVERSATIVO E OUTRAS ESTRUTURAS COM REPETIÇÕES VERBAIS}

\section{Introdução}

Neste capítulo pretendo apresentar os pontos principais de duas análises sobre estruturas com reduplicação verbal em português brasileiro e europeu (Bastos 2001; Bastos-Gee 2009; Martins 2007) semelhantes às construções com que-reportativo e queadversativo. Como essas estruturas foram analisadas dentro do modelo proposto por Nunes 2004, vou apresentar brevemente esse modelo antes de discutir detalhadamente essas análises. As propriedades dessas estruturas também serão comparadas com as propriedades das estruturas com que-reportativo e que-adversativo.

\subsection{Nunes 2004}

O modelo proposto por Nunes 2004 segue a teoria de movimento por cópia de Chomsky 1993, de acordo com a qual um elemento movido deixa uma cópia em seu lugar de origem, como ilustrado em (1) abaixo. Assumindo que a operação Linearizar do sistema computacional está em conformidade com o Axioma de Correspondência Linear (LCA, Kayne 1994), Nunes (2004) observa que há um problema para a linearização de (1b).

(1) a. John was kissed.

b. [ John [ was [ kissed John ] ] ]

O problema apontado por Nunes é que cópia mais alta de John c-comanda assimetricamente o verbo was, determinando a ordem linear <John, was >; porém, o verbo was c-comanda assimetricamente a cópia mais baixa de John, o que resultaria na sequência 〈was, John>. Assim, a sequência obtida dos dois resultados seria <John, was, $J o h n>$, o que, assumindo-se que as duas cópias de John são não-distintas, não constituiria uma ordem linear pois violaria a condição de assimetria (John precede was e was precede John) e a condição de irreflexibilidade (John precede a ele mesmo), definidas em (2) abaixo. 
(2) a. Assimetria:

Se $\alpha$ precede $\beta$, então $\beta$ não precede $\alpha$

b. Condição de irreflexibilidade:

Se $\alpha$ precede $\beta$, então $\alpha \neq \beta$.

Nunes então argumenta que a operação de Redução de Cadeias permite que uma ordem linear seja estabelecida. Redução de Cadeias é uma operação do componente fonológico que apaga o menor número de constituintes de uma cadeia não-trivial para obedecer ao LCA. Portanto, em uma sentença como em (1b) acima, o apagamento da cópia mais baixa através da Redução de Cadeias faz com que a sentença possa ser mapeada pelo LCA e linearizada, como ilustrado em (3) abaixo.

(3) [ John [ was [ kissed John ] ] ]

O ponto do modelo que é mais relevante para esta pesquisa e para as análises discutidas a seguir diz respeito à realização fonética de cópias múltiplas. Já que a Redução de Cadeias estabelece que constituintes não-distintos em uma cadeia nãotrivial devem ser apagados para respeitar linearização, línguas que permitem cópias-WH foneticamente realizadas, como em (4)-(5) abaixo, por exemplo, parecem ser uma contra-evidência para o modelo.

(4) Alemão (McDaniel, 1986 apud Nunes 2004:38)

Wen glaubt Hans wen Jakob gesehen hat?

whom thinks Hans wen Jakob seen has

'Who does Hans think Jakob saw?'

(5) Romani (McDaniel, 1986 apud Nunes 2004:38)

Kas misline kas o Demìri dikhlâ?

whom you-think whom Demir saw

'Who do you think Demir saw?'

Para dar conta de sentenças como as em (4)-(5) acima, Nunes baseia-se na operação fusão, no sentido da Morfologia Distribuída (Halle \& Marantz 1993), em que 
dois núcleos passam a ser computados como um único elemento terminal. Assumindo com Chomsky 1995 que o LCA não se aplica à estrutura interna das palavras, agindo após Morfologia, Nunes propõe que, em sentenças como (4)-(5) acima, a cópia-WH intermediária e o núcleo $\mathrm{C}$ sofreriam fusão morfológica, tornando a cópia-WH parte de um elemento terminal e, portanto, invisível para o LCA. Assim, somente a cópia mais alta e a mais baixa estariam visíveis para o LCA, sendo a mais baixa apagada. A representação da derivação está esquematizada em (6) abaixo, com a fusão representada por \#..+..\#.

(6) Nunes (2004: 40)

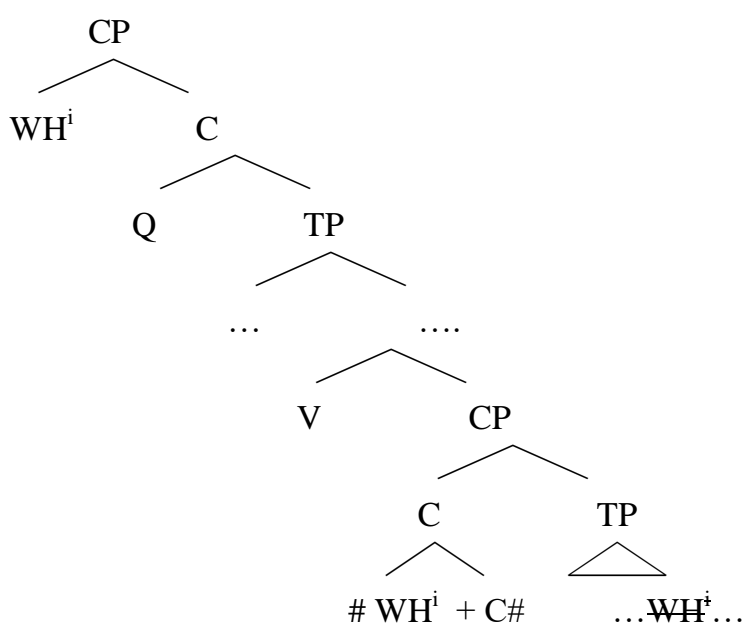

Um ponto importante é que esse modelo prevê que constituintes complexos, que não podem sofrer fusão, estão visíveis para a operação de Redução de Cadeias e têm de ser apagados, como os exemplos em (7) ilustram.

(7) Nunes (2004:39)

a. Alemão

*Wessen Buch glaubst du wessen Buch Hans liest?

whose book think you whose book Hans reads

'Whose book do you think Hans is reading?'

b. Romani

*Save chave mislinea save chave o Demiri dikhlâ?

which boy you-think which boy Demir saw 
'Who do you think Demir saw?'

\subsection{Bastos 2001/ Bastos-Gee 2009}

Como apontado por Bastos 2001 e Bastos-Gee 2009, é possível encontrar três tipos de estruturas que apresentam reduplicação verbal na mesma sentença em português brasileiro, como vemos abaixo em (8).

(8) Bastos-Gee (2009:162)

a.Tipo 1:

Temperar, o cozinheiro temperou o peixe (não a carne)

b.Tipo 2:

Temperar aquele peixe, o cozinheiro temperou (mas...)

c.Tipo 3:

Temperar peixe, o cozinheiro sempre tempera nos fins de semana.

Vemos que o tipo 1 apresenta apenas o verbo no infinitivo na periferia esquerda, enquanto que os tipos 2 e 3 apresentam os verbos no infinitivo com seu argumento interno. Segundo Bastos, a diferença entre os tipos 2 e 3 quanto ao constituinte inicial é que, se o argumento interno permite uma leitura específica (aquele peixe), trata-se do tipo 2 e se o argumento interno apresenta uma leitura genérica (peixe), trata-se do tipo 3. Nos três tipos, contudo, pode-se observar que as duas instâncias verbais devem estar em tempos verbais diferentes, sendo a primeira sempre no infinitivo e a segunda sempre com o verbo finito.

Bastos propõe que essas construções diferem quanto à forma em que são geradas: os tipos 1 e 2 são gerados por movimento, enquanto que o tipo 3 é gerado na base. Os testes em (9) evidenciam essa proposta de análise, já que mover constituintes de dentro de uma configuração de ilha sintática torna a sentença agramatical.

(9) Bastos-Gee (2009:164)

a. Tipo 1:

*Temperar, eu conheci [o cozinheiro que temperou o peixe]

b. Tipo 2: 
*Temperar aquele peixe, eu conheci [o cozinheiro que temperou], mas... ${ }^{3}$

c. Tipo 3:

Temperar peixe, eu conheço [um cozinheiro que (só) tempera nos fins de semana]

Bastos propõe que as estruturas analisadas não são compatíveis com a leitura de foco apresentacional, em que o constituinte focalizado responde ao constituinte interrogativo da pergunta, e também não são compatíveis com foco contrastivo, que anula um valor estabelecido anteriormente e introduz um novo valor. Os testes para foco apresentacional e foco contrastivo estão respectivamente apresentados em (10)-(12) abaixo, em que as letras maiúsculas mostram o foco da sentença.

(10) Bastos-Gee (2009:173-174)

Tipo 1:

a. Foco apresentacional:

$\mathrm{QC}^{4}$ : O que a Maria fez?

R: \#AFINAR, ela afinou o violino.

b. Foco contrastivo:

QC: A Maria TOCOU o violino dela?

R: \#AFINAR, ela afinou o violino (*e não tocar)

(11) Bastos-Gee (2009:174-175)

Tipo 2:

a. Foco apresentacional:

QC: O que o João fez?

R: \#COMER O BOLO, ele comeu (mas...)

b. Foco contrastivo:

QC: O João TOMOU A SOPA?

R: \#COMER A TORTA, ele comeu (*e não tomar a sopa)

\footnotetext{
3 A presença do mas na sentença (9b) é para garantir a entonação e interpretação relevantes que irei discutir mais adiante. O mas nesta sentença é fundamental pois sem a presença dele, associado à entonação relevante, a sentença é gramatical em PB graças ao fato de PB permitir objetos nulos dentro de ilhas (ver Galves 1989; Kato 1993; Cyrino 1994; Ferreira 2000).

${ }^{4} \mathrm{QC}=$ questão contextualizadora.
} 
(12) Bastos-Gee (2009:174-175)

Tipo 3:

a. Foco apresentacional:

QC: O que o João faz nos fins de semana?

R: \#JOGAR TÊNIS, ele joga nos fins de semana.

b. Foco contrastivo:

QC: O João pratica ioga nos fins de semana?

R: \#JOGAR TÊNIS, ele joga nos fins de semana (*e não praticar ioga)

Vemos em (10)-(12) acima que as sentenças estudadas por Bastos não passam nos testes de foco. Porém, se observarmos as sentenças em (13) abaixo, vemos que os constituintes destacados aparentam estar na periferia esquerda, são separados por entonação de vírgula e expressam informação velha que ainda é saliente no discurso, ou seja, esses constituintes apresentam todas as características de tópico descritas por Rizzi (1997). Com base nisso, Bastos (2000) conclui que esses constituintes são tópicos.

(13) a. Tipo 1:

QC: O João vendeu as sementes de girassol ou de milho ontem?

R: Vender, ele vendeu as sementes de girassol.

b. Tipo 2:

QC: O João vendeu as sementes de girassol na feira?

$\mathrm{R}$ : Vender as sementes de girassol, ele vendeu (mas...)

c. Tipo 3:

QC: O João vendeu semente na temporada de verão ou inverno?

R: Vender semente, ele vendeu no verão.

Observa-se que as construções do tipo 2, como em (14) abaixo, produzem uma expectativa, como se a oração estivesse incompleta. Essa expectativa aparece na forma de uma oração adversativa, que pode ser implícita ou não. Essa expectativa foi nomeada por Bastos de efeito-mas.

(14) Bastos (2001:63)

QC: O João comprou as rosas e arrumou no vaso? 


\section{R: Comprar as rosas, o João comprou (mas...)}

A questão do foco é importante para o efeito-mas, pois o efeito-mas nas estruturas de tipo 2 pode ser cancelado quando um elemento dentro da sentença é focalizado, como vemos nos exemplos em (15)-(16) abaixo.

(15) Bastos (2001:59)

\section{Com efeito-mas}

Vender a casa, o João vendeu (mas...)

(16) Bastos (2001:59)

\section{Sem efeito-mas}

a. Vender a casa, foi [Foco $O$ João] que vendeu.

b. Vender a casa, [Foco O JOÃO] vendeu.

Vemos em (15)-(16) acima que, nas construções do tipo 2, o foco está em distribuição complementar com o efeito-mas.

Dessa forma, para dar conta do cancelamento do efeito-mas quando há um elemento focalizado dentro de sentenças do tipo 2, Bastos assume que foco é um termo essencial para a informação associada a essas sentenças. Assim, quando o falante não focaliza um elemento dentro da sentença, ele não está fornecendo todas as informações necessárias. Não fornecendo todas as informações necessárias, surge essa sensação de sentença incompleta e, portanto, o efeito- $\mathrm{mas}^{5}$.

As estruturas do tipo 3 também apresentam o efeito-mas quando não possuem um argumento interno focalizado, como vemos em (17) abaixo. Os dados em (17) corroboram a análise de Bastos de que foco e efeito-mas estão em distribuição complementar.

(17) Bastos (2001: 59)

\section{a. Com efeito-mas}

Vender livro, eu tinha um amigo que vendia (mas...)

\footnotetext{
${ }^{5}$ A análise proposta por Bastos (2001)/ Bastos-Gee (2009) para o efeito-mas será melhor detalhada no capítulo 5 .
} 
Fazer brigadeiro, eu conheço uma doceira que faz (mas...)

\section{b. Sem efeito-mas}

Vender livro, eu tinha um amigo que vendia [Foco de porta em porta]

Fazer brigadeiro, eu conheço uma doceira que faz [Foco todos os dias]

Entretanto, com as estruturas de tipo 1 isso não ocorre; elas não apresentam o efeito-mas e o argumento interno, por não ter sido topicalizado, pode apresentar foco normalmente, como vemos nos dados em (18).

(18) Bastos (2001: 26)

a. QC: O que o João vendeu?

$\mathrm{R}:$ Vender, ele vendeu [F as sementes de girassol].

b. QC: Quem vendeu as sementes de girassol?

$\mathrm{R}:$ Vender, foi [F $\mathrm{O}$ João] que vendeu as sementes de girassol.

R':Vender, [F o João] vendeu as sementes de girassol.

Dessa forma, vemos que foco e o efeito-mas estão em distribuição complementar. Devido à esta distribuição complementar, temos que as estruturas do tipo 1 não desencadeiam o efeito-mas por apresentarem um elemento focalizado, enquanto que as estruturas do tipo 2 e 3 desencadeiam o efeito-mas, pois são possíveis sem elementos focalizados.

Outro ponto importante da análise de Bastos (2001) envolve as derivações sintáticas das três estruturas. Para dar conta das duas instâncias verbais dos tipos 1 e 2, Bastos assume a análise de Nunes 2004 apresentada em 2.1, em que cópias múltiplas podem ser realizadas foneticamente quando sofrem fusão morfológica.

Em uma sentença do tipo 1 como (19a) abaixo, temos que o núcleo verbal $v$ se move para Top $^{\circ}$ por excorporação ${ }^{6}$ para satisfazer o Critério de Tópico. Nessa posição, a base nua com a vogal temática (termina-) recebe flexão de infinitivo no componente morfológico, já que a pronúncia de uma base nua é impossível em português brasileiro. Após receber a flexão, ocorre a operação fusão, tornando terminar e os elementos contidos em Top invisíveis para o LCA, como vemos em (19b) abaixo.

\footnotetext{
${ }^{6}$ Bastos (2001, p. 112, nota 2) enfatiza que, seguindo Nunes (2001), o movimento de núcleo por excorporação é legítimo dentro da teoria de movimento por cópia, pois a cópia deixada pelo movimento (e realizada foneticamente) garante a integridade lexical da palavra.
} 
(19) a. Terminar, a Maria terminou a tese

b. (Bastos, 2001:119, adaptado)

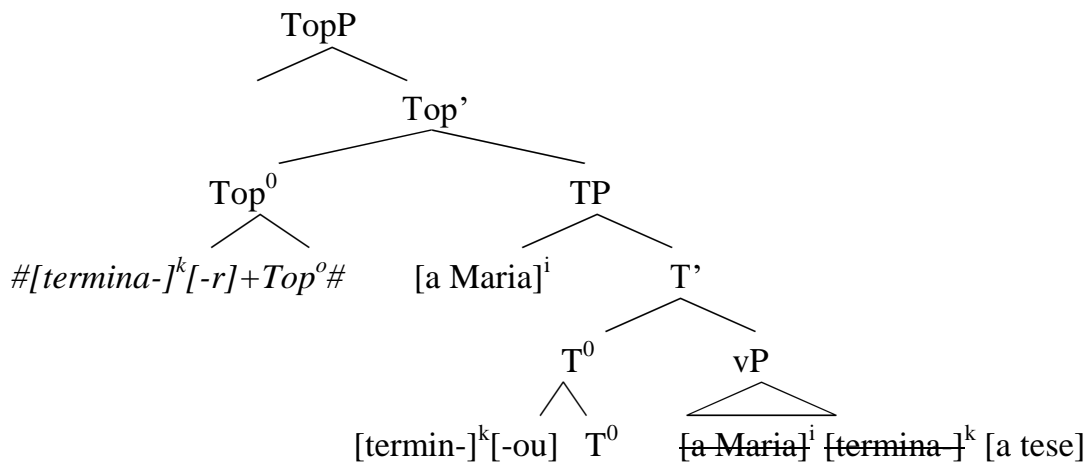

Para sentenças do tipo 2, como (20a) abaixo, o núcleo verbal se move para $\mathrm{T}^{\mathbf{o}}$ e o $v \mathrm{P}$ se move para Spec,TopP. O núcleo Top entra em uma relação de Spec-núcleo com o $\nu \mathrm{P}$ que se moveu para o especificador de TopP, permitindo que o núcleo de $v \mathrm{P}$ receba em Spec, TopP o morfema de infinitivo. Após receber o infinitivo, essa cópia sofre a operação morfológica fusão, tornando-se invisível para o LCA, não sendo apagada pela Redução de Cadeias. A representação da derivação sintática está em (20b) abaixo.

(20) a. Terminar aquela tese, a Maria terminou.

b. (Bastos, 2001:122, adaptado).

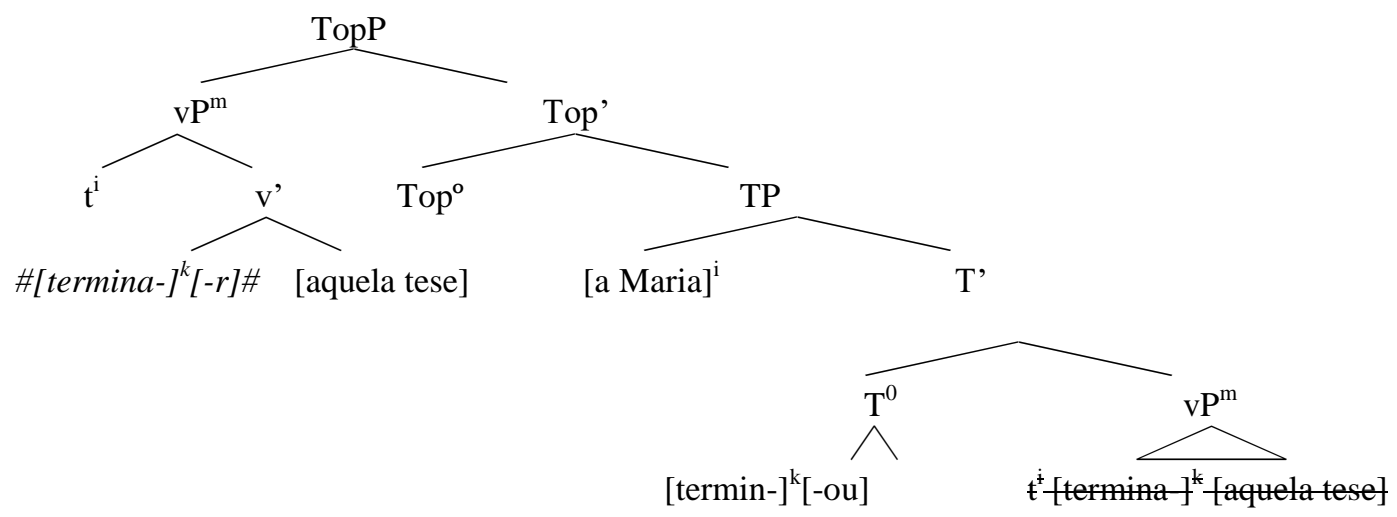

Para sentenças do tipo 3, como (21a) abaixo, Bastos (2001: 104) propõe que as instâncias verbais relevantes são dois itens distintos. A derivação, portanto, ocorre com $\mathrm{o} v \mathrm{P}$ do verbo infinitivo sendo gerado diretamente na base em Spec, TopP, como apresentado em (21b) abaixo. 
(21) a. Varrer casa, o João varre nos fins de semana.

b. Bastos (2001: 105)

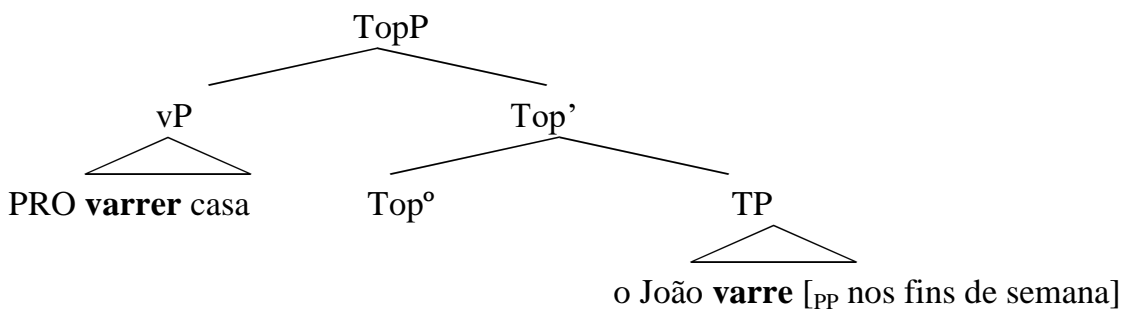

Uma evidência apontada por Bastos de que as duas instâncias verbais são distintas é a possibilidade da segunda instância poder ser substituída pela pro-forma fazer isso, como mostra (22) abaixo, o que não é possível paras os tipos 1 e 2, como ilustrado em (23) abaixo.

(22) Tipo 3 (Bastos 2001: 78)

Vacinar cachorro, todo veterinário faz isso.

(23) a. Tipo 1 (Bastos 2001:80)

*Vacinar, o veterinário fez isso com o cachorro.

b. Tipo 2 (Bastos 2001:79)

*Vacinar o Butox, o veterinário fez isso (mas...)

\subsubsection{Contrastando com que-reportativo e que-adversativo}

Nesta seção irei apresentar as semelhanças e diferenças entre as estruturas com $q u e$-reportativo e que-adversativo e as estruturas com topicalização de projeções verbais do português brasileiro mostradas na seção anterior (Bastos 2001; Bastos-Gee 2009).

\subsubsection{Repetição verbal idêntica dentro das estruturas}

Como visto anteriormente em (22) e (23) acima, as estruturas do tipo 3, por terem o $v \mathrm{P}$ com verbo infinitivo gerado na base, podem ter a segunda instância verbal 
substituída por uma pro-forma fazer isso. Já com as estruturas do tipo 1 e 2 isso não pode ocorrer.

As estruturas com que-reportativo e que-adversativo também não podem ter a segunda instância verbal substituída por uma pro-forma, como vemos em (24)-(25) abaixo.

(24) Que-reportativo

QC: O veterinário vacinou o cachorro?

$\mathrm{R}$ : *Que ele vacinou, ele fez isso (mas...)

(25) Que-adversativo

QC: O veterinário vacinou o cachorro?

$\mathrm{R}: * N a ̃ o$, mas que ele deveria vacinar, ele deveria fazer isso.

\subsubsection{Efeito-mas}

As construções com que-reportativo também possuem o efeito-mas apresentado na seção 2.2 acima para as estruturas de topicalização do tipo 2 e 3 . Como vemos nas sentenças em (26) abaixo, construções com que-reportativo geram uma expectativa (a oração coordenada adversativa) de que há alguma informação nova implícita. A oração coordenada adversativa pode inclusive ficar implícita, como nas estruturas de Bastos.

(26) Que-reportativo

a. QC: O Pedro vende verduras mais barato?

$\mathrm{R}$ : Que ele vende mais barato, ele vende (mas as verduras são velhas).

b. QC: A Maria saiu com o cachorro pra passear?

R: Que ela saiu com o cachorro, ela saiu (mas...)

As estruturas com que-adversativo, por outro lado, não geram o efeito-mas, como vemos nos exemplos em (27) abaixo. Essa diferença entre as estruturas com quereportativo e que-adversativo será explorada no capítulo 4.

(27) a. QC: O Pedro vende verduras mais barato? 
R: Não, mas que ele poderia vender, ele poderia.

b. QC: Você vai pedir esse hambúrguer?

R: Sim, mas que eu não deveria pedir, eu não deveria.

\subsubsection{Cancelamento do efeito-mas}

Para Bastos, as estruturas do tipo 2 têm o efeito-mas cancelado quando um elemento está focalizado na sentença, como apresentado na seção 2.2 em (28)-(29) repetido abaixo em (28).

(28) Bastos (2001:59)

\section{Com efeito-mas}

Vender a casa, o João vendeu (mas...)

(29) Bastos (2001: 59)

\section{Sem efeito-mas}

a. Vender a casa, foi [Foco $o$ João] que vendeu.

b. Vender a casa, [Foco O JOÃO] vendeu.

Já as construções com que-reportativo não são aceitáveis na presença de um constituinte focalizado, como vemos em (30) abaixo.

(30) a. Sem foco

QC: O João vendeu a casa?

R: Que o João vendeu a casa, ele vendeu (mas...)

b. Com foco

QC: O João vendeu a casa?

R: \#Que ele vendeu a casa, ele vendeu [Foco ontem].

Há, no entanto, um caso em que as estruturas com que-reportativo perdem a obrigatoriedade do efeito-mas: se acrescentarmos uma sentença encaixada de verbo epistêmico com um sujeito na primeira pessoa do singular, como vemos no contraste entre (31)-(32) abaixo. 
(31) a. Que o João comeu o bolo, a Maria acha que ele comeu (mas...)

b. Que a Maria leu o livro, o professor acredita que ela leu (mas...)

c. Que o Pedro fez a tarefa, a Ana percebeu que ele fez (mas...)

(32) a. Que o João comeu o bolo, eu acho que ele comeu.

b. Que a Maria leu o livro, eu acredito que ela leu.

c. Que o Pedro fez a tarefa, eu percebi que ele fez.

Um ponto interessante não observado por Bastos é que o mesmo ocorre em suas estruturas de tipo 2 e tipo 3, ou seja, o efeito-mas deixa de ser obrigatório quando inserimos uma encaixada de verbo epistêmico com sujeito em primeira pessoa do singular, como vemos no contraste entre (33)-(34) e (35)-(36) abaixo.

(33) Tipo 2:

a. Comer o bolo, a Maria acha que o João comeu (mas...)

b. Ler o livro, o Pedro acredita que a Maria leu (mas...).

c. Fazer a tarefa, a Ana percebeu que o Pedro fez (mas...).

(34) Tipo 3:

a. Comer bolo, a Maria acha que o João come (mas...).

b. Ler livros, o Pedro acredita que a Maria lê (mas...).

c. Fazer tarefas de casa, a Ana percebeu que o Pedro faz (mas...).

(35) Tipo 2:

a. Comer o bolo, eu acho que o João comeu.

b. Ler o livro, eu acredito que a Maria leu.

c. Fazer a tarefa, eu percebi que o Pedro fez.

(36) Tipo 3:

a. Comer bolo, eu acho que o João come.

b. Ler livros, eu acredito que a Maria lê.

c. Fazer tarefas de casa, eu percebi que o Pedro faz. 


\subsubsection{Efeito-mas com outros itens lexicais}

Um fato não comentado por Bastos (2001)/ Bastos-Gee (2009) é que a oração coordenada adversativa que caracteriza o efeito-mas nas estruturas com infinitivo topicalizado pode aparecer com outros itens lexicais, como só e já, como vemos em (37)-(38) abaixo.

(37) Tipo 2

a. Lavar o carro, o João lavou, mas não encerou.

b. Lavar o carro, o João lavou; só (que) não encerou.

c. Lavar o carro, o João lavou; já a moto eu não sei.

(38) Tipo 3

a. Lavar carro, o João lava, mas não encera.

b. Lavar carro, o João lava; só (que) não encera.

c. Lavar carro, o João lava; já moto eu não sei.

Nas estruturas com que-reportativo, a adversativa também pode aparecer com esses outros itens lexicais, como vemos em (39) abaixo.

(39) a. QC: O João não disse que vai comer esse bolo?

R: Que ele vai comer, ele vai; só (que) não disse quando.

b. QC: Você fez a sobremesa para amanhã?

R: Que eu fiz, eu fiz; só (que) não aquela que você pediu.

c. QC: O João vai pro casamento?

R: Que ele vai, ele vai; já a esposa dele eu não sei.

d. QC: Vai ter prova escrita e oral amanhã?

R: Que vai ter prova escrita, vai; já prova oral eu não tenho certeza.

Vemos que tanto o só quanto o já podem ser substituídos pelo mas. Porém, só não pode aparecer nos contextos em que já aparece e vice-versa, como vemos em (40) abaixo. 
(40) a. QC: O João não disse que vai comer esse bolo?

R: Que ele vai comer, ele vai, só/mas/*já não disse quando.

b. QC: Você fez a sobremesa para amanhã?

R: Que eu fiz, eu fiz, só/mas/*já não aquela que você pediu.

c. QC: O João vai pro casamento?

R: Que ele vai, ele vai, já/mas/*só a esposa dele eu não sei.

d. QC: Vai ter prova escrita e oral amanhã?

R: Que vai ter prova escrita, vai, já/mas/*só prova oral eu não tenho certeza.

Além da distribuição complementar entre só e já nas estruturas com quereportativo $^{7}$ que vemos em (40) acima, também há a diferença que nas estruturas com que-reportativo só permite um complementizador que enquanto mas/já não permitem, como vemos nos contrastes em (41) abaixo.

(41) a. QC: O João não disse que vai comer esse bolo?

R1: Que ele vai comer, ele vai, só (que) não disse quando.

R2: Que ele vai comer, ele vai, mas (*que) não disse quando.

b. QC: Você fez a sobremesa para amanhã?

R1: Que eu fiz, eu fiz só (que) não aquela que você pediu.

R2: Que eu fiz, eu fiz mas (*que) não aquela que você pediu.

c. QC: O João vai pro casamento?

R: Que ele vai, ele vai, já/mas (*que) a esposa dele eu não sei.

Uma explicação para a possibilidade de mas, só e já será proposta no capítulo 5.

\subsubsection{Tipo de constituinte}

\footnotetext{
${ }^{7}$ Diferentemente do que ocorre com as estruturas de Bastos e com que-reportativo, o que-adversativo não permite que a adversativa seja substituída por outros itens lexicais, como vemos nos exemplos em (i) abaixo.

(i) a. QC: O João vai vir jantar em casa hoje?

R: Não, mas/*já/*só *(que) ele podia vir, ele podia.

b. QC: Você faz esses bolos para vender?

R: Não, mas/*já/*só *(que) eu queria fazer, eu queria

c. QC: A Maria vai pro casamento?

R: Vai, mas/*já/*só *(que) ela não queria ir, ela não queria.
} 
Simplificadamente, as estruturas de topicalização de projeções verbais apresentam os constituintes em (42) abaixo.

(42) a. Tipo 1

[v Escrever],[тр o João escreveu o relatório].

b. Tipo 2

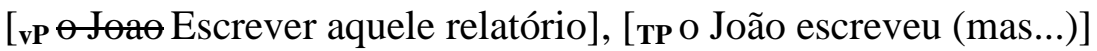

c. Tipo 3

[vP PRO Escrever relatórios], [TP o João escreve durante a semana].

Já as estruturas com que-reportativo envolvem aparentemente um $\mathrm{CP}$, como vemos em (43) abaixo.

(43) [ст Que o João escreveu o relatório], [тт ele escreveu (mas...)]

Para as estruturas com que-adversativo temos aparentemente o mesmo padrão, como exemplificado em (44) abaixo.

(44) $\left[\right.$ CoordP $^{8}$ Mas [[ $\mathbf{C P}$ que ele deveria escrever] $]$, [TP ele deveria]].

Vemos que nenhuma das estruturas de topicalização de projeções verbais se assemelha às estruturas com que-reportativo e que-adversativo quanto aos tipos de constituintes.

\subsubsection{Caráter reportativo}

Uma observação interessante não notada por Bastos (2001)/ Bastos-Gee (2009), é que as estruturas com topicalização de projeções verbais estudadas pela autora podem aparecer em contextos sem antecedente discursivo, ou seja, nenhuma parte da estrutura precisa ter aparecido no discurso para que uma sentença seja adequada, como vemos em (45) abaixo.

\footnotetext{
${ }^{8}$ CoordP $=$ Coordination Phrase, sintagma de coordenação, assumindo Munn (1993).
} 
(45) Estruturas com infinitivo topicalizado

a. Tipo 1

QC: Você vai sair ou preencher aquele relatório que está faltando?

R: Hoje é domingo, eu vou sair. Trabalhar, eu trabalho durante a semana.

b. Tipo 2

QC: Não sabia que você gostava tanto de ler literatura nas férias!

R: Claro, ler aqueles livros teóricos, eu leio durante o ano letivo.

c. Tipo 3

QC: O João já falou com o síndico?

R: Acho que sim. Resolver problema, ele resolve rápido.

Quanto às estruturas com que-reportativo, isso não ocorre, pois se não houver a repetição do contexto discursivo anterior, as sentenças com que-reportativo ficam inadequadas, como vemos nos contrastes em (46) abaixo.

(46) Estruturas com que-reportativo

a. QC: Não sabia que você gostava tanto de viajar!

R: \#Claro! Que eu fico em casa o ano todo, eu fico; mas se eu pudesse, não ficava.

b. QC: Você vai mesmo pedir esse hambúrguer calórico?

R: \#Sim, que eu como salada em casa, eu como (mas eu não gosto).

c. QC: O João pagou a dívida?

R: \#Que eu disse pra ele pagar, eu disse (mas ele não pagou)

Já as estruturas com que-adversativo não apresentam esse caráter reportativo obrigatório. Como estão em configurações adversativas, as estruturas apresentam oposição ao contexto, podendo exibir formas verbais diferentes das do contexto anterior, como vemos em (47) abaixo.

(47) Estruturas com que-adversativo

a. QC: O Pedro quer comprar um apartamento?

R: Não, mas que ele quer alugar, ele quer. 
b. QC: O João pagou a dívida?

R: Não, mas que ele disse que ia pagar, ele disse.

c. QC: A Maria submeteu o artigo?

R: Não, mas que ela terminou de escrever, ele terminou.

\subsubsection{Morfologia verbal de tempo}

Diferente do que ocorre nas estruturas estudadas por Bastos, em que o verbo na posição de tópico tem morfologia de infinitivo mas está associado a um verbo finito, nas estruturas com que-reportativo e que-adversativo os tempos verbais obrigatoriamente devem ser idênticos, como mostra o contraste entre (48) e (49)/(50) abaixo.

(48) a. Tipo 1:

Comer, ele comeu o bolo.

b. Tipo 2:

Comer o bolo, ele comeu (mas...)

c. Tipo 3:

Comer bolo, ele come nos fins de semana.

(49) Que-reportativo

a. Que o João comeu o bolo, ele comeu (mas...)

b. *Que o João comeu o bolo, ele come (mas...)

c. *Que o João come o bolo, ele comeu (mas...)

(50) Que-adversativo

a. Mas que eu comeria o bolo, comeria.

b. *Mas que eu comeria o bolo, como.

c. *Mas que eu como o bolo, comeria.

\subsubsection{Negação}

Ao comparar as três estruturas de Bastos com as estruturas com que-reportativo e que-adversativo, nota-se que a inserção de negação nas estruturas discutidas por 
Bastos deve ocorrer apenas na segunda instância verbal, já que as sentenças são agramaticais se as negativas forem duplas, como vemos no contraste entre (51) e (52) abaixo.

(51) a. Tipo 1:

*Não temperar, o cozinheiro não temperou o peixe.

b. Tipo 2:

*Não temperar aquele peixe, o cozinheiro não temperou (mas...)

c. Tipo 3:

*Não temperar peixe, o cozinheiro não tempera nos fins de semana.

(52) a. Tipo 1:

Temperar, o cozinheiro não temperou o peixe.

b. Tipo 2:

Temperar aquele peixe, o cozinheiro não temperou (mas...).

c. Tipo 3:

Temperar peixe, o cozinheiro não tempera nos fins de semana.

O motivo da impossibilidade de negação dupla nas estruturas é explicado por Bastos (2001:91) levando em conta que é impossível a negação acompanhar o verbo no infinitivo, pois o constituinte na periferia esquerda é um $v$ ou um $v \mathrm{P}$, e a projeção de negação $(\mathrm{NegP})$ seria uma categoria mais alta que $v \mathrm{P}$.

Já para as estruturas com que-reportativo e que-adversativo, se colocarmos a sentença na negativa, as duas instâncias verbais devem permanecer negativas, como mostram as sentenças em (53) abaixo para estruturas com que-reportativo.

(53) Que-reportativo

QC: Aí em São Paulo não choveu ontem?

a. Que não choveu, não choveu (mas o tempo estava feio)

b. *Que choveu, não choveu (mas o tempo estava feio).

c. *Que não choveu, choveu (mas o tempo não estava feio). 
As estruturas com que-adversativo também necessitam de uma negação dupla, como vemos em (54) abaixo.

(54) Que-adversativo

QC: Você vai à festa?

a. Sim, mas que eu não queria ir, eu não queria.

b. *Sim, mas que eu não queria ir, eu queria.

c. *Sim, mas que eu queria ir, eu não queria.

\subsubsection{Repetição com constituintes morfologicamente complexos}

Como visto na seção 2.2, as estruturas analisadas por Bastos são derivadas através da operação morfológica fusão, o que impede que as cópias tenham constituintes morfologicamente complexos, como mostram os exemplos em (55) abaixo.

(55) a.Tipo 1:

*Dever temperar, o cozinheiro devia temperar o peixe.

b. Tipo 2:

*Dever temperar aquele peixe, o cozinheiro devia temperar (mas...)

c. Tipo 3:

*Dever temperar peixe, o cozinheiro devia temperar.

Quantos às estruturas com que-reportativo e que-adversativo, temos que elas são gramaticais com constituintes morfologicamente complexos, como vemos em (56) e (57) abaixo.

(56) Que-reportativo

QC: O João não devia tomar o remédio de gripe?

$\mathrm{R}$ : Que ele devia tomar o remédio, ele devia tomar (mas...) ${ }^{9}$.

(57) Que-adversativo

\footnotetext{
${ }^{9}$ Embora a elisão do verbo no infinitivo soe mais natural em sentenças como (56) e (57), sua presença também é claramente possível.
} 
QC: A Maria tomou os remédios na hora certa?

R: Não, mas que ela devia tomar, ela devia tomar.

\subsubsection{Geração na base ou por movimento}

Como vimos em 2.2, as estruturas de Bastos diferem quanto ao constituinte inicial ser gerado na base ou por movimento. Os testes com ilhas sintáticas em (9), repetidos abaixo em (58), mostram que somente a estrutura de tipo 3 tem o constituinte inicial gerado na base.

(58) a. Tipo 1:

*Temperar, eu conheci [o cozinheiro que temperou o peixe]

b. Tipo 2:

*Temperar aquele peixe, eu conheci [o cozinheiro que temperou] (mas...)

c. Tipo 3:

Temperar peixe, eu conheço [um cozinheiro que (só) tempera nos fins de semana]

Ao aplicar esse teste nas construções com que-reportativo, vemos que algumas são aceitáveis enquanto outras não, como mostram os exemplos em (59)-(61) abaixo.

(59) Oração Relativa

a. QC: O João vende carro?

R: Que ele vende carro, [eu conheço uma pessoa que disse que ele vende].

b. QC: A Maria devolveu o livro da biblioteca?

R: Que ela devolveu o livro, [eu encontrei com um aluno que falou que ela devolveu].

c. QC: O Pedro fez a lição de casa?

R: Que ele fez a lição de casa, [eu falei com a professora que disse que ele fez]

(60) Oração com estruturas coordenadas

a. QC: O Pedro vende carro?

$\mathrm{R}:{ }^{*}$ Que ele vende carro, ele vende e aluga. 
b. QC: A Rita faz ginástica nos fins de semana?

$\mathrm{R}: *$ Que ela faz ginástica, ela faz e anda de bicicleta.

C. QC: A Maria faz doces pra vender?

$\mathrm{R}$ : *Que ela faz doces, ela faz e vende.

(61) Oração com adjunto

a. QC: A Maria terminou com o Pedro?

$\mathrm{R}$ : *Que ela terminou, ela ficou com peso na consciência [depois que terminou].

b. QC: O João vendeu o carro?

$\mathrm{R}$ : *Que ele vendeu o carro, ele teve o maior prejuízo [depois que ele vendeu] c. QC: O João limpou o apartamento?

R: *Que ele limpou o apartamento, ele deixou tudo brilhando [depois que ele limpou].

Com as estruturas com que-adversativo o mesmo ocorre, as sentenças só são aceitáveis com orações relativas, como vemos em (62)-(64) abaixo.

(62) Oração relativa

a. QC: O João vende carro?

R: Não, mas que o Pedro vende, [eu conheço uma pessoa que disse que ele vende].

b. QC: A Maria vai pra festa junina da escola?

R: Não, mas que ela queria ir, [eu encontrei com um aluno que falou que ela queria].

c. QC: O Pedro fez a prova hoje?

R: Não, mas que ele vai fazer amanhã, [eu falei com a professora que disse que ele vai fazer]

(63) Oração com estruturas coordenadas

a. QC: O Pedro vende carro?

R: *Não, mas que ele vende moto, ele vende e aluga.

b. QC: A Rita faz ginástica nos fins de semana? 
$\mathrm{R}$ : *Não, mas que ela corre no parque, ela corre e anda de bicicleta.

c. QC: A Maria faz doces pra vender?

$\mathrm{R}$ : *Não, mas que ela faz salgados, ela faz e vende.

(64) Oração com adjunto

a. QC: A Maria terminou com o Pedro?

R: *Não, mas que ela traiu ele, ela ficou com peso na consciência [depois que ela traiu].

b. QC: O João vendeu a casa?

$\mathrm{R}$ : *Não, mas que ele reformou a casa, ele teve o maior prejuízo [depois que ele reformou].

c. QC: O João limpou o apartamento?

R: *Não, mas que ele sujou, ele deu uma desculpa [depois que ele sujou].

Esses resultados incongruentes sugerem que no caso das relativas, a aparente gramaticalidade de (59) e (62) se deve a outra estrutura. Esse ponto será melhor explorado na seção 4.3. Por ora, irei assumir, com base nos efeitos de extração de orações coordenadas e orações adjuntos, que tanto que-reportativo quanto queadversativo são sensíveis a ilhas e, portanto, indicam derivação por movimento.

\subsubsection{Resumo das características}

As características dos três tipos de estruturas com constituinte topicalizado comparadas com as das estruturas com que-reportativo e que-adversativo estão resumidas no Quadro 1 abaixo. 
Quadro 1. Comparação entre estruturas com que-reportativo e que-adversativo e estruturas com infinitivos topicalizados

\begin{tabular}{|l|l|l|l|l|l|l|l|}
\hline & $\begin{array}{l}\text { Morfologia } \\
\text { da repetição } \\
\text { verbal } \\
\text { idêntica }\end{array}$ & $\begin{array}{l}\text { Negação } \\
\text { dupla }\end{array}$ & $\begin{array}{l}\text { Sensibilidade } \\
\text { a }\end{array}$ & $\begin{array}{l}\text { Forma } \\
\text { sintáticas } \\
\text { verbal } \\
\text { complexa na } \\
\text { repetição }\end{array}$ & $\begin{array}{l}\text { Efeito- } \\
\text { mas }\end{array}$ & $\begin{array}{l}\text { Efeito-mas } \\
\text { com outras } \\
\text { conjunções }\end{array}$ & $\begin{array}{l}\text { Propriedade } \\
\text { reportativa } \\
\text { obrigatória }\end{array}$ \\
\hline $\begin{array}{l}\text { Que- } \\
\text { reportativo }\end{array}$ & SIM & SIM & SIM & SIM & SIM & SIM & SIM \\
\hline $\begin{array}{l}\text { Que- } \\
\text { adversativo }\end{array}$ & SIM & SIM & SIM & SIM & NÃO & - & NÃO \\
\hline $\begin{array}{l}\text { Infinitivo } \\
\text { topicalizado do } \\
\text { tipo 1 }\end{array}$ & NÃO & NÃO & SIM & NÃO & NÃO & - & NÃO \\
\hline $\begin{array}{l}\text { Infinitivo } \\
\text { topicalizado do } \\
\text { tipo 2 }\end{array}$ & N $\tilde{O} O$ & NÃO & SIM & NÃO & SIM & SIM & NÃO \\
\hline $\begin{array}{l}\text { Infinitivo } \\
\text { topicalizado do } \\
\text { tipo 3 }\end{array}$ & NÃO & NÃO & NÃO & NÃO & SIM & SIM & NÃO \\
\hline
\end{tabular}

Como vemos no Quadro 1 acima, as estruturas com que-reportativo e queadversativo não só diferem entre si em relação a algumas propriedades, mas também diferem dos três tipos de estruturas estudadas por Bastos.

\subsection{Martins 2007}

Também assumindo a análise de Nunes (2004) para a realização fonética de múltiplas cópias, apresentada na seção 2.1, Martins (2007) investiga estruturas com duas instâncias verbais idênticas no português europeu (PE). A reduplicação verbal em português europeu é uma estratégia gramatical para expressar desacordo enfático em sentenças afirmativas, como vemos em (65) e (66) abaixo, e em respostas enfáticas para perguntas-sim/não, como vemos em (67).

(65) Martins (2007: 87)

QC: Ele não comprou o carro.

R: Ele comprou o carro, comprou. 
(66) Martins (2007:92)

QC: A Maria ainda não se penteou.

R: A Maria penteou-se, penteou.

(67) Martins (2007: 81)

QC: O João não comprou o carro, pois não?

R: Comprou, comprou.

Assumindo as propostas de Laka (1990) e Zanuttini $(1994,1997)$ de que toda oração inclui um núcleo funcional de polaridade $\Sigma$, Martins propõe que estruturas enfáticas de resposta em PE ativam o núcleo funcional de polaridade $\Sigma$, em que os traços de afirmação ou negação estão localizados, e também o núcleo funcional $\mathrm{C}$, em que traços de ênfase estão presentes.

Assim, na derivação de sentenças declarativas enfáticas, como (65) acima, o verbo se move para $\mathrm{T}$, depois para $\Sigma$ e para $\mathrm{C}$, seguido pelo movimento da projeção $\Sigma \mathrm{P}$ para Spec, CP. Em C, o verbo sofre reanálise morfológica, tornando-se uma cópia invisível para o LCA, como mostra a derivação em (68) abaixo.

(68) Derivação de sentença declarativa enfática (Martins, 2007:87, adaptado)

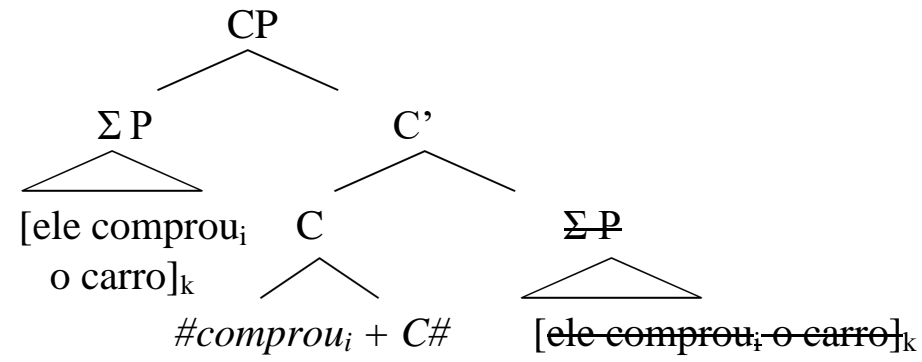

Para as respostas de perguntas-sim/não, como em (67) acima, a derivação se dá com o movimento do verbo para $\Sigma$. A partir desse núcleo, o verbo se move para $\mathrm{C}$, onde a cópia mais alta do verbo sofre a operação morfológica fusão, o que torna essa instância verbal invisível para o LCA. Segundo Martins (2007:86), o movimento do verbo para $\Sigma$ licencia elipse de TP quando um antecedente discursivo apropriado está disponível no contexto, como mostra a derivação em (69) abaixo. 
(69) Derivação de sentença-resposta para perguntas-sim/não (Martins, 2007:86, adaptado)

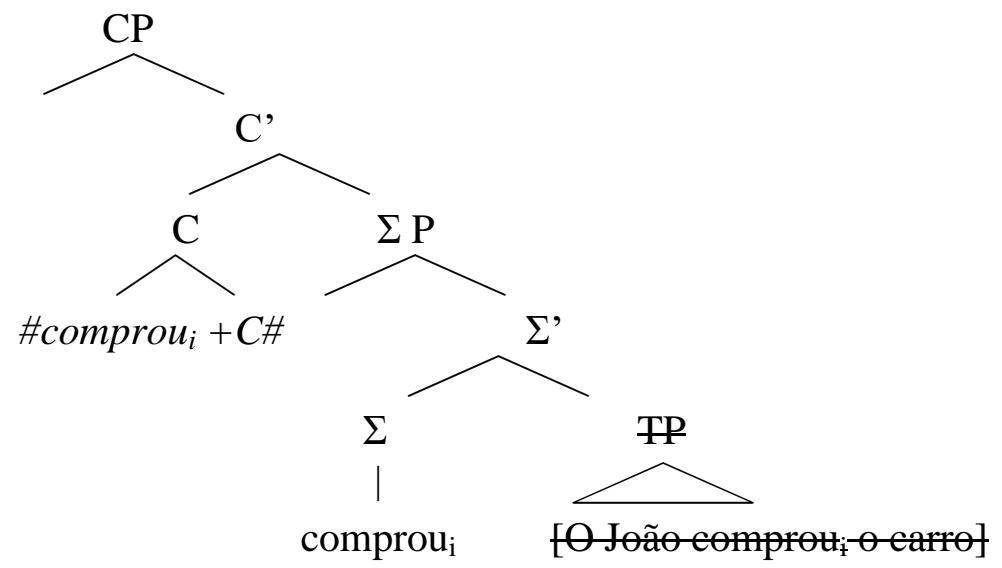

\subsubsection{Contrastando com que-reportativo e que-adversativo}

Nesta seção irei apresentar as semelhanças e diferenças entre as estruturas de repetição verbal do português europeu analisadas por Martins (2007) e as estruturas com que-reportativo e que-adversativo.

\subsubsection{Morfologia de tempo verbal}

Tanto as estruturas de reduplicação verbal em PE quanto as estruturas com quereportativo e que-adversativo requerem que o tempo verbal da reduplicação seja o mesmo para que as sentenças sejam gramaticais, como vemos em (70) abaixo para as estruturas de Martins e em (71) e (72) abaixo para as que-reportativas e queadversativas, respectivamente.

(70) QC: O João não comprou o carro, pois não?

R: Comprou, comprou.

$\mathrm{R}$ ': *Compra, comprou

(71) QC: O João comeu o bolo que eu fiz?

a. Que ele comeu o bolo, ele comeu (mas...) 
b. *Que ele comeu o bolo, ele come (mas...)

c. *Que ele come o bolo, ele comeu (mas...)

(72) QC: Você comeu o bolo que eu fiz?

a. Não, mas que eu queria comer, eu queria.

b. *Não, mas que eu queria comer, eu quero.

c. *Não, mas que eu quero comer, eu queria.

\subsubsection{Caráter reportativo}

As sentenças com repetição verbal em português europeu de Martins possuem propriedades enfáticas e reportativas, ou seja, as estruturas repetem o contexto antecedente para serem pragmaticamente aceitáveis, como mostra o contraste entre (73) e (74) abaixo.

(73) Ana Maria Martins (comunicação pessoal)

a. QC: O João não gosta de filmes de ação.

$\mathrm{R}$ : \#Ele disse que assistiria, disse.

b. QC: O João ainda não chegou.

R: \#Ele saiu do trabalho mais cedo, saiu.

(74) Martins (2007: 87; 85)

a. QC: Ele não comprou o carro.

R: Ele comprou o carro, comprou.

b. QC: O João não vai vir.

R: O João vai vir, vai.

As sentenças com que-reportativo também possuem essa propriedade reportativa dependente de contexto discursivo anterior, como exemplificado em (46) acima e repetido abaixo em (75).

(75) Que-reportativo

a. QC: Não sabia que você gostava tanto de viajar! 
R: \#Claro! Que eu fico em casa o ano todo, eu fico; mas se pudesse, não ficava.

b. QC: Você vai mesmo pedir esse hambúrguer calórico?

R: \#Sim, que eu como salada em casa, eu como (mas eu não gosto)

c. QC: O João pagou a dívida?

R: \#Que eu disse pra ele pagar, eu disse (mas ele não pagou)

Para as sentenças com que-adversativo isso não ocorre, como mostrado em (47) repetido abaixo como (76).

(76) Estruturas com que-adversativo

a. QC: Você precisa trabalhar até aos domingos?

R: Não preciso, mas que eu quero, eu quero.

b. QC: O João pagou a dívida?

R: Não, mas que ele disse que ia pagar, ele disse.

c. QC: A Maria submeteu o artigo?

R: Não, mas que ela terminou de escrever, ele terminou.

\subsubsection{Negação}

Como discutido anteriormente na seção 2.2.1.8, as sentenças com quereportativo e que-adversativo permitem negação desde que a negação seja dupla, como nos exemplos em (53) e (54) repetidos abaixo como (77) e (78).

(77) Que-reportativo

QC: Aí em São Paulo não choveu ontem?

a. Que não choveu, não choveu (mas o tempo estava feio)

b. *Que choveu, não choveu (mas o tempo estava feio).

c. *Que não choveu, choveu (mas o tempo não estava feio).

(78) Que-adversativo

QC: Você vai à festa?

a. Sim, mas que eu não queria ir, eu não queria. 
b. *Sim, mas que eu não queria ir, eu queria.

c. *Sim, mas que eu queria ir, eu não queria.

Para as estruturas de Martins, a negação é impossível em qualquer uma das instâncias verbais, já que as estruturas com reduplicação verbal do PE expressam desacordo enfático somente em sentenças afirmativas, como mostraram os dados em (79) abaixo.

(79) Martins (2007, p. 85, adaptado)

QC: O João ganhou a loteria.

a.*O João não ganhou a loteria, ganhou.

b. *O João não ganhou a loteria, não ganhou.

c. * O João ganhou a loteria, não ganhou.

\subsubsection{Repetição com constituintes morfologicamente complexos}

Outra diferença entre as estruturas com que-reportativo e com que-adversativo e as estruturas de reduplicação enfática estudadas por Martins é que, por envolverem múltiplas cópias realizadas foneticamente (ver seção 2.1 para apresentação do modelo de Nunes 2004), as estruturas de reduplicação enfática não são possíveis com constituintes morfologicamente mais complexos, como apresentado em (80)-(82) abaixo.

(80) Martins (2007:89)

QC: Ele não pode sair de casa.

R1: Ele pode sair de casa, pode.

R2: *Ele pode sair de casa, pode sair.

(81) Martins (2007:85)

QC: O João não vai vir.

R1: O João vai vir, vai.

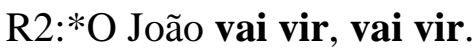


(82) Martins (2007:105)

QC: Ele não fotocopiou o livro sem autorização, pois não?

R:??Fotocopiou, fotocopiou.

A diferença das estruturas estudadas por Martins e as sentenças com quereportativo e que-adversativo é que estas permitem que a repetição ocorra mesmo com constituintes morfologicamente mais complexos, como vemos em (83) e (84) abaixo (ver nota 9).

(83) a. QC: O João vai vir pra festa?

R: Que ele vai vir pra festa, ele vai vir (mas ele não queria).

b. QC: Será que o João devia tomar o remédio pra gripe?

R: Que ele devia tomar o remédio, ele devia tomar (mas ele não aceita).

c. QC: A Maria pode sair de casa hoje?

R: Que ela pode sair, ela pode sair (mas ela não quer).

(84) a. QC: O João vai vir pra festa?

R: Não, mas que ele queria vir, ele queria vir.

b. QC: A Maria tomou os remédios na hora certa?

R: Não, mas que ela devia tomar, ela devia tomar.

c. QC: A Maria pode sair de casa hoje?

R: Não, mas que ela pode sair amanhã, ela pode sair.

\subsubsection{Efeito-mas}

A ausência de efeito-mas nas construções com repetição verbal em português europeu é uma diferença se comparado com que-reportativo e uma semelhança se comparado com que-adversativo, como vemos nos dados em (85)-(87) abaixo, em que só as estruturas com que-reportativo em (86) apresentam o efeito-mas.

(85) Reduplicação verbal do PE

QC: O João comprou o carro, pois não?

R: Comprou, comprou. 
(86) Que-reportativo

QC: O João comprou o carro?

R: Que ele comprou o carro, ele comprou (mas...)

(87) Que-adversativo

QC: O João comprou o carro?

R: Não, mas que ele podia comprar, ele podia.

Como vimos na análise de Bastos na seção 2.2, foco está em distribuição complementar com o efeito-mas. Portanto, a ausência de efeito-mas nas estruturas com reduplicação verbal do PE indica, como me apontou Jairo Nunes (comunicação pessoal), que deve haver foco sobre o valor de verdade das sentenças em PE.

\subsubsection{Resumo das características}

As características das estruturas com reduplicação verbal em português europeu comparadas com as estruturas com que-reportativo e que-adversativo estão resumidas no Quadro 2 abaixo.

Quadro 2. Comparação entre estruturas com que-reportativo e que-adversativo e estruturas de reduplicação verbal do português europeu

\begin{tabular}{|l|l|l|l|l|l|}
\hline & $\begin{array}{l}\text { Morfologia da } \\
\text { repetição } \\
\text { verbal idêntica }\end{array}$ & $\begin{array}{l}\text { Negação } \\
\text { dupla }\end{array}$ & $\begin{array}{l}\text { Forma verbal } \\
\text { complexa na } \\
\text { repetição }\end{array}$ & Efeito-mas & $\begin{array}{l}\text { Propriedade reportativa } \\
\text { obrigatória }\end{array}$ \\
\hline Que-reportativo & SIM & SIM & SIM & SIM & SIM \\
\hline Que-adversativo & SIM & SIM & SIM & NÃO & NÃO \\
\hline $\begin{array}{l}\text { Reduplicação } \\
\text { verbal em PE }\end{array}$ & SIM & NÃO & NÃO & NÃO & SIM \\
\hline
\end{tabular}

\subsection{Conclusão}


Neste capítulo foi apresentado o quadro teórico necessário para entender as estruturas com repetição verbal já estudadas no português brasileiro e no português europeu. Além disso, foi feita uma comparação entre essas estruturas e as estruturas com que-reportativo e que-adversativo. Como conclusão parcial, temos que apesar de parecerem semelhantes, as estruturas com que-reportativo e que-adversativo possuem mais diferenças do que semelhanças com as estruturas de repetição verbal analisadas no português, como podemos ver no quadro abaixo, que aglutina as informações dos quadros 1 e 2 .

Quadro 3. Comparação entre as estruturas discutidas

\begin{tabular}{|l|l|l|l|l|l|l|}
\hline & $\begin{array}{l}\text { Morfologia } \\
\text { da repetição } \\
\text { verbal } \\
\text { idêntica }\end{array}$ & $\begin{array}{l}\text { Negação } \\
\text { dupla }\end{array}$ & $\begin{array}{l}\text { Repetição verbal } \\
\text { gerada por } \\
\text { movimento }\end{array}$ & $\begin{array}{l}\text { Forma verbal } \\
\text { complexa ra } \\
\text { repetição }\end{array}$ & Efeito-mas & $\begin{array}{l}\text { Propriedade } \\
\text { reportativa } \\
\text { obrigatória }\end{array}$ \\
\hline $\begin{array}{l}\text { Que- } \\
\text { reportativo }\end{array}$ & SIM & SIM & SIM & SIM & SIM & SIM \\
\hline $\begin{array}{l}\text { Que- } \\
\text { adversativo }\end{array}$ & SIM & SIM & SIM & SIM & NÃO & NÃO \\
\hline $\begin{array}{l}\text { Infinitivo } \\
\text { topicalizado do } \\
\text { tipo 1 }\end{array}$ & NÃO & NÃO & SIM & NÃO & NÃO & NÃO \\
\hline $\begin{array}{l}\text { Infinitivo } \\
\text { topicalizado do } \\
\text { tipo 2 }\end{array}$ & NÃO & NÃO & SIM & NÃO & SIM & NÃO \\
\hline $\begin{array}{l}\text { Infinitivo } \\
\text { topicalizado do } \\
\text { tipo 3 }\end{array}$ & NÃO & NÃO & NÃO & NÃO & SIM & NÃO \\
\hline $\begin{array}{l}\text { Reduplicação } \\
\text { verbal em PE }\end{array}$ & SIM & NÃO & SIM & NÃO & NÃO & SIM \\
\hline
\end{tabular}

Vemos no Quadro 3, portanto, que as duas estruturas com que-reportativo e queadversativo possuem propriedades e características diferentes das outras estruturas com repetição verbal em português, requerendo, portanto, uma análise independente. 


\section{CAPÍTULO 3: QUESTÕES DE IDENTIDADE}

\section{Introdução}

Nas estruturas com que-reportativo, as ocorrências verbais devem retomar o contexto, como vimos na seção 2.2.1.6. A pergunta que surge é se as estruturas com $q u e$-reportativo necessitam retomar do contexto o item lexical (o verbo tem que ser o mesmo) ou a forma morfológica dos verbos. Este capítulo procura investigar esses aspectos nas estruturas com que-reportativo e compará-las com as estruturas com queadversativo.

\subsection{Verbos sinônimos}

O intuito desta seção é explorar dois casos de identidade com verbos sinônimos: entre contexto (QC) e as estruturas com que-reportativo e que-adversativo; e identidade dentro dos blocos das estruturas. Para tanto, farei uso dos verbos sinônimos por e colocar, morrer e falecer, terminar e concluir, analisando se esses verbos sinônimos são licenciados nestes casos ou não.

Para a repetição entre contexto e estrutura, temos os dados em (1)-(3) abaixo.

(1) Que-reportativo

a. QC: O João colocou a roupa toda no cesto?

R1: Que ele colocou, ele colocou (mas...)

R2: \#Que ele pôs, ele pôs (mas...)

b. QC: A Maria pôs o livro na estante certa?

R1: Que ela pôs, ela pôs (mas...)

R2: \#Que ela colocou, ela colocou (mas...)

(2) Que-reportativo

a. QC: A irmã do João morreu ontem?

R1: Que ela morreu, ela morreu (mas...)

R2: \#Que ela faleceu, ela faleceu (mas...)

b. QC: É verdade que o primo da Maria faleceu? 
R1: Que ele faleceu, ele faleceu (mas...)

R2: \#Que ele morreu, ele morreu (mas...)

(3) Que-reportativo

a. QC: O João terminou o artigo?

R1: Que ele terminou, ele terminou (mas...)

R2: \#Que ele concluiu, ele concluiu (mas...)

b. QC: A Maria concluiu o curso de inglês?

R1: Que ela concluiu, ela concluiu (mas...)

R2: \#Que ela terminou, ela terminou (mas...)

Vemos em (1)-(3) acima que os verbos sinônimos não licenciam o contexto retomado nas construções com que-reportativo, o que mostra que essas estruturas têm que repetir o mesmo verbo do contexto para serem pragmaticamente bem formadas.

Para as estruturas com que-adversativo, por não apresentarem a necessidade de retomar o contexto anterior, a previsão é que os verbos sinônimos são licenciados e aceitos com naturalidade, o que se confirma, como vemos em (4)-(6) abaixo.

(4) Que-adversativo

a. QC: O João colocou a roupa toda no cesto?

R: Não, mas que ele pôs as camisas, ele pôs.

b. QC: A Maria pôs o livro na estante certa?

R: Não, mas que ela colocou na primeira estante, ela colocou.

(5) Que-adversativo

a. QC: A prima do João faleceu ontem?

R: Não, mas que o tio dele morreu semana passada, morreu.

b. QC: É verdade que a prima do João morreu ontem?

R: Não, mas que o tio dele faleceu semana passada, faleceu.

(6) Que-adversativo

a. QC: O João terminou todo o artigo?

R: Não, mas que ele concluiu a primeira parte, ele concluiu. 
b. QC: A Maria concluiu o curso de inglês?

R: Não, mas que ela terminou o de espanhol, ela terminou.

Os dados em (7)-(12) abaixo mostram que tanto que-reportativo quanto queadversativo não permitem que o segundo verbo seja sinônimo do primeiro verbo, ou seja, a sentença só é gramatical quando os dois verbos são iguais.

(7) Que-reportativo

a. QC: O João colocou a roupa toda no cesto?

R: *Que ele colocou, ele pôs (mas...)

b. QC: A Maria pôs o livro na estante certa?

R: *Que ela pôs, ela colocou (mas...)

(8) Que-reportativo

a. QC: A irmã do João morreu ontem?

$\mathrm{R}: *$ Que ela morreu, ela faleceu (mas...)

b. QC: É verdade que o primo da Maria faleceu?

$\mathrm{R}: *$ Que ele faleceu, ele morreu (mas...)

(9) Que-reportativo

a. QC: O João terminou o artigo?

$\mathrm{R}$ : *Que ele terminou, ele concluiu (mas...)

b. QC: A Maria concluiu o curso de inglês?

$\mathrm{R}$ : *Que ela concluiu, ela terminou (mas...)

(10) Que-adversativo

a. QC: O João colocou a roupa toda no cesto?

R: *Não, mas que ele colocou as camisas, ele pôs.

b. QC: A Maria pôs o livro na estante certa?

$\mathrm{R}: * N a ̃ o$, mas que ele colocou na primeira estante, ele pôs.

(11) Que-adversativo

a. QC: A prima do João faleceu ontem? 
$\mathrm{R}$ : *Não, mas que o tio dele faleceu semana passada, morreu.

b. QC: É verdade que a prima do João morreu ontem?

$\mathrm{R}$ : *Não, mas que o tio dele morreu semana passada, faleceu.

(12) Que-adversativo

a. QC: O João terminou todo o artigo?

$\mathrm{R}$ : *Não, mas que ele terminou a primeira parte, ele concluiu.

b. QC: A Maria concluiu o curso de inglês?

$\mathrm{R}$ : *Não, mas que ela concluiu o de espanhol, ela terminou.

Podemos concluir que no caso de identidade entre contexto e estruturas com que-reportativo, estas são mais sensíveis ao item lexical do que ao significado do verbo (ver (1)-(3) acima), enquanto que as estruturas com que-adversativo não apresentam essa sensibilidade (ver (4)-(6) acima). No caso dos verbos sinônimos no primeiro verbo ou no verbo da repetição, temos que as duas ocorrências verbais das estruturas devem ser idênticas tanto nas estruturas com que-reportativo quanto nas com que-adversativo (ver (7)-(12) acima).

\subsection{Identidade na morfologia de tempo}

Esta seção se propõe a investigar dois aspectos: primeiro, se há identidade entre os tempos verbais do contexto $(\mathrm{QC})$ e das estruturas com que-reportativo e queadversativo e entre os blocos das estruturas; segundo, se as estruturas analisadas são mais sensíveis à forma morfossintática do tempo verbal ou ao sentido do tempo verbal.

Para as estruturas com que-reportativo que retomam o contexto, temos que os tempos verbais obrigatoriamente devem ser morfologicamente idênticos ao contexto, como vemos no contraste em (13)-(14) abaixo. É interessante notar que, mesmo quando os tempos verbais são aparentemente equivalentes, como presente com sentido de futuro e o verbo no presente com auxiliar $i r$, a resposta não é pragmaticamente bem formada (ver (14b) e (14c) abaixo).

(13) a. QC: A Maria vende doces?

R: Que ela vende doces, ela vende (mas...) 
b. QC: O Pedro viaja amanhã?

R: Que ele viaja amanhã, ele viaja (mas...)

c. QC: A Maria vai submeter o artigo amanhã?

R: Que ela vai submeter, ela vai (mas...)

(14) a. QC: A Maria vende doces?

R: \#Que ela vendeu doces, ela vendeu (mas...)

b. QC: O Pedro viaja amanhã?

R: \#Que ele vai viajar, ele vai (mas...)

c. QC: A Maria vai submeter o artigo amanhã?

R: \#Que ela submete amanhã, ela submete (mas...)

Já as estruturas com que-adversativo não necessitam que os tempos verbais sejam morfologicamente iguais aos do contexto, como vemos em (15) abaixo.

(15) a. QC: O João comeu o bolo que eu fiz?

R: Não, mas que ele sempre come, ele come.

b. QC: A Maria vende doces?

R: Não, mas que ela vendia na época da crise, ela vendia.

c. QC: O Pedro viaja amanhã?

R: Não, mas que ele vai viajar na próxima semana, ele vai.

Vemos em (14) acima que as estruturas com que-reportativo são sensíveis ao tempo verbal do contexto, enquanto que as estruturas com que-adversativo em (15) acima não são.

Quanto ao tempo verbal ser idêntico nas duas ocorrências do verbo nas estruturas, em (16)-(17) abaixo vemos a impossibilidade de o tempo verbal ser diferente nas ocorrências do verbo tanto em que-reportativo quanto em que-adversativo, mesmo quando os tempos verbais são aparentemente equivalentes, como o presente com sentido de futuro e o futuro com auxiliar ir.

(16) Que-reportativo

a. QC: O Pedro viaja amanhã? 
$\mathrm{R}: *$ Que ele viaja amanhã, ele vai viajar (mas...)

b. QC: A Maria vai submeter o artigo amanhã?

$\mathrm{R}$ : *Que ela vai submeter amanhã, ela submete (mas...)

(17) Que-adversativo

a. QC: O Pedro viaja amanhã?

R: *Não, mas que ele viaja na próxima semana, ele vai viajar.

b. QC: A Maria vai submeter o artigo amanhã?

$\mathrm{R}:$ *Não, mas que ela vai submeter na próxima semana, ela submete.

Os dados em (16)-(17) acima nos mostram que as duas ocorrências verbais das estruturas com que-reportativo e que-adversativo devem ser idênticas quanto à morfologia de tempo verbal.

\subsection{Identidade em modo}

No modo subjuntivo, as estruturas com que-reportativo e que-adversativo não são gramaticais quando a repetição do verbo envolve apenas o verbo no modo subjuntivo, como vemos nos exemplos em (18) e (19) abaixo.

(18) a. QC: A Maria pediu que o João limpasse o apartamento?

$\mathrm{R}: *$ Que ele limpasse o apartamento, ele limpasse (mas...)

b. QC: O João queria que a Maria fosse pra festa?

R: *Que ela fosse pra festa, ela fosse (mas...)

c. QC: O Pedro esperava que a Maria pagasse o aluguel de novo?

$\mathrm{R}:{ }^{*}$ Que ela pagasse o aluguel, ela pagasse (mas...)

d. QC: O João suspeitava que a Maria estivesse grávida?

R: *Que ela estivesse grávida, ela estivesse (mas...)

(19) a. QC: A Maria queria que o João ligasse hoje?

$\mathrm{R}$ : *Não, mas que ele desse notícias, ele desse.

b. QC: O Pedro quer que a Maria vá para a cerimônia de casamento?

R: *Não, mas que ela compre o presente, ela compre. 
c. QC: O Pedro suspeitava que a Maria fosse pra festa com o João?

$\mathrm{R}$ : *Não, mas que ela fosse acompanhada, ela fosse.

d. QC: O João esperava que a Maria ganhasse a competição?

$\mathrm{R}:$ *Não, mas que ela chegasse até em terceiro lugar, ela chegasse.

Como o verbo no subjuntivo nas estruturas com que-reportativo não pode ser retomado sozinho, a previsão é que o segundo bloco das estruturas precisa retomar o predicado da matriz da QC, o que se confirma com os exemplos em (20) abaixo.

(20) a. QC: A Maria pediu que o João limpasse o apartamento?

R: Que ele limpasse o apartamento, ela pediu que ele limpasse (mas...)

b. QC: O João queria que a Maria fosse pra festa?

R: Que ela fosse pra festa, ele queria que ela fosse (mas...)

c. QC: O Pedro esperava que a Maria pagasse o aluguel de novo?

R: Que ela pagasse o aluguel, ele esperava que ela pagasse (mas...)

d. QC: O João suspeitava que a Maria estivesse grávida?

R: Que ela estivesse grávida, ele suspeitava que ela estivesse (mas...)

O contraste entre (20) acima e (21) abaixo mostra que outros predicados diferentes do da matriz não soam naturais, o que enfatiza o caráter reportativo das estruturas.

(21) a. QC: A Maria pediu que o João limpasse o apartamento?

R: \#Que ele limpasse o apartamento, ela queria que ele limpasse (mas...)

b. QC: O João queria que a Maria fosse pro casamento?

$\mathrm{R}$ : \#Que ela fosse pro casamento, ele pediu que ela fosse (mas...)

c. QC: O Pedro esperava que a Maria pagasse o aluguel de novo?

$\mathrm{R}$ : \#Que ela pagasse, ele queria que ela pagasse (mas...)

d. QC: O João queria que a Maria ganhasse a competição?

R: \#Que ela ganhasse a competição, ele esperava que ela ganhasse (mas...)

Como as estruturas com que-adversativo não precisam retomar o contexto obrigatoriamente, isso não ocorre; as estruturas soam naturais tanto quando apresentam 
o mesmo predicado da matriz da QC, como em (22), quanto quando apresentam outros predicados, como em (23).

(22) a. QC: A Maria queria que o João ligasse hoje?

R: Não, mas que ele desse notícias, ela queria que ele desse.

b. QC: O Pedro quer que a Maria vá para a cerimônia de casamento?

R: Não, mas que ela compre o presente, ele quer que ela compre.

c. QC: O Pedro suspeitava que a Maria fosse pra festa com o João?

R: Não, mas que ela fosse acompanhada, ele suspeitava que ela fosse.

d. QC: O João esperava que a Maria ganhasse a competição?

R: Não, mas que ela chegasse até em terceiro lugar, ele esperava que ela chegasse.

(23) a. QC: A Maria queria que o João ligasse hoje?

R: Não, mas que ele desse notícias, ela pediu que ele desse.

b. QC: O Pedro quer que a Maria vá para a cerimônia de casamento?

R: Não, mas que ela vá para a festa, ele espera que ela vá.

c. QC: O Pedro suspeitava que a Maria fosse pra festa com o João?

R: Não, mas que ela fosse acompanhada, ele achava que ela fosse.

d. QC: O João esperava que a Maria ganhasse a competição?

R: Não, mas que ela chegasse até em terceiro lugar, ele queria que ela chegasse.

É interessante notar que a diferença entre que-reportativo e que-adversativo a respeito da repetição do predicado verbal do contexto discursivo se mantém nessa configuração em modo subjuntivo. Nos exemplos em (22) acima, vemos que os verbos subordinantes utilizados nas construções com que-adversativo são diferentes dos verbos subordinantes das questões contextualizadoras, enquanto que com que-reportativo isso não seria possível, como explicitado na seção 2.2.1.5. Esses dados reforçam a necessidade de reportação do contexto que as estruturas com que-reportativo apresentam.

\subsection{Identidade em traços- $\varphi$}


Vimos nas seções anteriores que as estruturas com que-reportativo dependem de uma certa identidade do contexto. Porém, como vemos nos dados em (24) abaixo, com relação aos traços- $\varphi$, tanto no caso da concordância quanto no caso dos pronomes, essa identidade não é requerida.

(24) a. QC: Você quer ir pra festa da Maria?

$\mathrm{R}$ : Que eu quero ir, eu quero (mas...)

b. QC: Eu fui mal educada com o professor ontem?

R: Que você foi mal educada, você foi (mas...)

c. QC: O Pedro te convidou pra festa?

R: Que ele me convidou, ele convidou (mas...)

Como me apontou Andrés Saab (comunicação pessoal), estruturas de reportação, como estruturas em discurso indireto ou perguntas eco, por exemplo, não pedem identidade de concordância, como vemos nos exemplos em (25) abaixo.

(25) a. Discurso indireto

A: Eu preciso ir pro médico amanhã.

B: O falante A disse que ele precisa ir pro médico amanhã.

b. Pergunta eco

A: Eu vou comprar um livro amanhã.

B: Você vai comprar o quê?

Como não dependem do contexto anterior, as estruturas com que-adversativo não apresentam identidade com traços- $\varphi$ também, como esperado e apresentado em (26) abaixo.

(26) a. QC: Você quer ir pra festa da Maria?

R: Não, mas que eu quero presentear ela, eu quero.

b. QC: Eu fui mal educada com o professor ontem?

R: Não, mas que você exagerou, você exagerou.

c. QC: O Pedro te convidou pra festa? 
R: Sim, mas que eu não vou, eu não vou.

Um ponto interessante é identidade com demarcação de lugar, como o exemplo em (27) abaixo.

(27) a. QC: (por telefone) Você não veio aqui ontem!

R: Que eu fui (aí), eu fui, mas eu saí de pressa e não te encontrei.

Em (27) acima temos verbos diferentes na QC e na resposta com que-reportativo, porém a sentença com que-reportativo é gramatical e pragmaticamente bem formada. Esse exemplo em (27) acima sugere, como me apontou Jairo Nunes (comunicação pessoal), que os verbos ir e vir de certa forma concordam com a localização do falante e funcionam como marcas de concordância, sendo, assim, desconsiderados para identidade assim como traços- $\varphi$ e advérbios de lugar, como aí na sentença em (27) acima.

Vemos então que a falta de identidade de traços- $\varphi$ nas estruturas com quereportativo não é uma contra-evidência para a necessidade de reportação das estruturas com que-reportativo. Essa conclusão também se estende para as estruturas de reduplicação enfática do português europeu (Martins 2007), como exemplificado em (28) abaixo, que reportam o contexto, como vimos na seção 2.3.1.2, mas não exigem total identidade com os traços- $\varphi$, já que traços- $\varphi$ não necessitam de identidade em casos de reportação, como vimos nos exemplos de discurso indireto e perguntas ecos em (25) acima.

(28) Martins (2007: 88)

QC: Eu não estava cantando.

$\mathrm{R}$ : Tu estavas cantando, estavas

\subsection{Aparente contra-exemplos}

Nesta seção irei apresentar e analisar três contra-exemplos para a análise de que as estruturas, principalmente as com que-reportativo, são mais sensíveis à forma 
morfossintática dos verbos: o caso do presente histórico, o caso do modo subjuntivo e o caso das respostas negativas.

\subsubsection{O caso do presente histórico}

A seção 3.3 acima mostrou que as estruturas com que-reportativo são mais sensíveis à forma morfossintática do tempo verbal do que ao sentido do tempo verbal. Com isso em mente, consideremos (29) e (30) abaixo, que parecem mostrar que as estruturas com que-reportativo estão mais sensíveis ao sentido de passado do verbo da QC.

(29) QC: Olha o que me aconteceu ontem! Eu vou até a sua casa, ouço barulho, bato a campainha e você não atende a porta!

R: Que eu não atendi a porta, eu não atendi, mas é que eu estava com fone de ouvido com música alta.

R': \#Que eu não atendo, eu não atendo, mas é que eu estava com fone de ouvido com música alta.

(30) QC: Olha o que me aconteceu ontem! Eu vou até a sua casa, ouço barulho, toco a campainha e você não atende a porta!

R: É, mas que eu não escutei, eu não escutei!

R': \#É, mas que eu não escuto, eu não escuto!

Para analisar estruturas como as de (29) e (30) acima me baseio na análise de Saab (2014) sobre narrativas orais em espanhol envolvendo presente histórico e licenciamento de elipse. O presente histórico, no contexto de narrativas orais com um advérbio desencadeador de passado, por exemplo, ontem ou semana passada, acarreta um significado de passado, como vemos no exemplo em (31) abaixo, com o advérbio e os verbos no presente histórico destacados.

(31) Saab (2014: 5)

¡Adiviná qué me pasó ayer!

guess what me happened yesterday 
Estoy tomando una cervecita en el bar y entonces veo

am.I drinking a beer in the bar and then see.I

a mi mujer besándose con mi mejor amigo.

ACC my wife kissing with my best friend

'Guess what happened to me yesterday! I am drinking a beer in the bar and then I see my wife kissing my best friend.'

Assim, o licenciamento ou não de elipse pelo antecedente contextual em presente histórico mostra se esse antecedente necessita ter uma identidade semântica (uma identificação com o significado de passado) ou uma identidade morfossintática (ter a mesma morfossintaxe verbal), para que a elipse seja licenciada.

Os dados em (32) abaixo mostram que com presente histórico não há licenciamento de elipse em narrativas orais do espanhol.

(32) Saab (2014: 8-9)

QC: Adiviná qué me pasó ayer! Estoy tomando una cervecita en el guess what me happened yesterday am.1sg drinking a beer in the bar...

bar

'Guess what happened to me yesterday! I am drinking a beer at a bar...'

R: Qué casualidad! *Yo también estaba tomando una cervecita en el bar. what coincidence I also was/am drinking a beer in the bar 'What a coincidence! Me too!'

Porém, Saab demonstra que quando o antecedente está no passado, o licenciamento de elipse nas narrativas orais do espanhol acontece, como vemos em (33) abaixo.

(33) Saab (2014:9)

QC: Adiviná qué me pasó ayer! Estaba tomando una cervecita en el guess what me happened yesterday am.1sg drinking a beer in the bar...

bar

'Guess what happened to me yesterday! I am drinking a beer at a bar...' 
R: Qué casualidad! Yo también estabar. what coincidence I also was drinking a beer in the bar 'What a coincidence! Me too!'

A análise que Saab faz desses casos é que o presente histórico não licencia elipse porque o constituinte apagado está no passado e, para a elipse acontecer, é necessário que o antecedente do constituinte seja morfossintaticamente idêntico, mostrando que apenas o significado de passado não licencia a elipse. Portanto, o licenciamento de elipse nas narrativas orais em espanhol é mais sensível à forma, ou seja, a forma morfossintática do tempo verbal precisa ser idêntica para que a elipse seja licenciada.

Para as estruturas com que-reportativo, que recuperam o contexto anterior obrigatoriamente, inspirando-me nos contextos de Saab, temos os seguintes dados em (34)-(36) abaixo.

(34) QC: Olha o que me aconteceu ontem! Eu estou no bar, vejo você entrando, chamo seu nome e você não me atende!

R: Que eu não atendi, eu não atendi, mas é que eu não te ouvi chamando.

R': \#Que eu não atendo, eu não atendo, mas é que eu não te ouvi chamando.

(35) QC: Olha o que me aconteceu ontem! Estou no shopping, vejo que está passando um filme com seu ator favorito, te mando uma mensagem no celular e você não me responde!

R: Que eu não respondi, eu não respondi, mas é que eu não estou mais usando aquele número de celular.

R': \#Que eu não respondo, eu não respondo, mas é que eu não estou mais usando aquele número de celular.

(36) QC: Você não acredita o que me aconteceu ontem! Estou em uma cafeteria, vejo você passando na rua, te chamo e você não volta pra falar comigo!

R: Que eu não voltei, eu não voltei, mas é que eu não te vi na cafeteria.

R': \#Que eu não volto, eu não volto, mas é que eu não te vi na cafeteria. 
Vemos em (34)-(36) acima que os casos de que-reportativo só são pragmaticamente boas se estiverem no passado, não importando se a forma verbal da questão contextualizadora está no presente histórico.

Para que-adversativo, temos os dados em (37)-(39) abaixo, os quais mostram que as estruturas com que-adversativo também parecem ser mais sensíveis ao significado de passado do verbo do que à morfossintaxe de presente.

(37) QC: Olha o que me aconteceu ontem! Eu estou no bar, vejo você entrando, chamo seu nome e você não vem falar comigo!

R: É, mas que eu não te escutei, eu não te escutei.

R': \#É, mas que eu não te escuto, eu não te escuto.

(38) QC: Olha o que me aconteceu ontem! Estou no shopping, vejo que está passando um filme com seu ator favorito, te mando uma mensagem no celular e você não me responde!

R: Sim, mas que eu não recebi a mensagem, eu não recebi.

R': \#Sim, mas que eu não recebo a mensagem, eu não recebo.

(39) QC: Você não acredita o que me aconteceu ontem! Estou em uma cafeteria, vejo minha namorada passando na rua com outro homem, chamo e ela não fala comigo!

$\mathrm{R}$ : É, mas que ela te viu, ela te viu.

R': \#É, mas que ela te vê, ela te vê.

Analisando os dados de (37)-(39) acima, as estruturas com que-reportativo e que-adversativo são mais sensíveis ao sentido de passado do que à forma morfológica dos verbos. Ser mais sensível ao sentido do que à forma morfológica parece contraditório com os dados da seção 3.1, já que verbos sinônimos, que possuem o mesmo sentido não são licenciados nas estruturas com que-reportativo, e com seção 3.2 sobre morfologia do tempo verbal. Porém, a aparente contradição não existe; o que temos são restrições pragmáticas do presente histórico, como me informou Andrés Saab (comunicação pessoal). Ao utilizar o presente histórico em uma narração cotidiana, o falante está trazendo fatos do passado para o presente, mas o passado fica sinalizado 
através de um advérbio; assim, há uma perspectiva de passado mesmo com as ações descritas no presente. O ouvinte não está nessa perspectiva de passado, o que resulta na impossibilidade de respostas em presente histórico. Quando falante e ouvinte estão na mesma perspectiva de passado, como em um contexto de reconstrução de uma cena de crime, em que há um acordo pragmático de que todas as ações descritas estão no passado, a resposta em presente histórico é possível, como vemos em (40) abaixo.

(40) a. QC: Na noite de sexta-feira, o assassino entra na casa e coloca as chaves sobre a mesa.

R: Que ele entra na casa, ele entra, mas as chaves já estão sobre a mesa.

b. QC: Minutos antes do roubo, o ladrão encontra a vítima no supermercado.

R: Sim, mas que a vítima não conversa com ele no supermercado, ela não conversa.

Dessa forma, vemos que o fato de respostas não serem possíveis em presente histórico se deve às restrições pragmáticas do próprio presente histórico. Assim, podemos analisar as estruturas com que-reportativo e que-adversativo como estruturas sensíveis à forma morfossintática dos verbos.

\subsubsection{O caso do modo subjuntivo}

Petersen (2011) mostra que alguns complementos subjuntivos em PB licenciados por advérbios como talvez, possivelmente e provavelmente, como os exemplos em (41) abaixo, apresentam controle obrigatório de sujeito da mesma forma que sentenças indicativas (ver e.g Ferreira 2000, Rodrigues 2004).

(41) Petersen (2011: 25)

a. O João ${ }_{i}$ acha que talvez $t_{i}$ vá ao cinema hoje.

b. O João $\mathrm{i}_{\mathrm{i}}$ acha que possivelmente $t_{i}$ vá ao cinema hoje.

c. O João $\mathrm{i}_{\mathrm{i}}$ acha que provavelmente $t_{i}$ vá ao cinema hoje. 
Testando a identidade entre contexto e as estruturas com que-reportativo e queadversativo nessa configuração com advérbios desencadeadores de subjuntivo, temos os dados em (42) e (43) abaixo.

(42) Que-reportativo

a. QC: A Maria disse que o João talvez trabalhe o dia todo amanhã.

R: \#Que ele trabalha o dia todo amanhã, ele trabalha (mas...)

b. QC: O João trabalha o dia todo amanhã?

R: \#Que ele talvez trabalhe amanhã, talvez ele trabalhe (mas...)

(43) Que-adversativo

a. QC: A Maria disse que o João talvez trabalhe o dia todo amanhã.

R: Amanhã não, mas que ele trabalha no próximo domingo, ele trabalha.

b. QC: O João trabalha o dia todo amanhã?

R: Amanhã não, mas que ele talvez trabalhe no próximo domingo, talvez ele trabalhe.

Em (42) acima vemos que o advérbio talvez no contexto com uma resposta envolvendo estrutura com que-reportativo no indicativo é pragmaticamente inaceitável. Uma QC no indicativo com uma resposta envolvendo estrutura com que-reportativo com o advérbio talvez também é pragmaticamente inaceitável. Já as estruturas com que-adversativo em (43) acima, como não retomam o contexto, são pragmaticamente aceitáveis tanto com o advérbio talvez na QC quanto com QC no indicativo.

O que surpreende é que as estruturas com que-reportativo na configuração com advérbios desencadeadores de subjuntivo, são gramaticais apresentando morfossintaxe verbal diferente, como mostra (44).

(44) a. QC: O João viaja amanhã pra Alemanha?

$\mathrm{R}$ : Que ele viaja, talvez ele viaje.

b. QC: O João submete o artigo amanhã?

R: Que ele submete o artigo, talvez ele submeta.

c. QC: O Pedro entrega o trabalho amanhã?

R: Que ele entrega o trabalho amanhã, talvez ele entregue. 
A diferença morfossintática entre os verbos do primeiro e segundo bloco da estrutura deveria tornar a sentença agramatical, como vimos na seção 2.2.1.1, porém, nesse caso, a sentença é gramatical. Também é importante mencionar que nesses casos com o advérbio talvez, o efeito-mas deixa de ser obrigatório.

A estranheza das sentenças com as ocorrências verbais diferente em (44) acima se deve ao fato de que as estruturas com o advérbio talvez não são estruturas com quereportativo. Além de não apresentarem o efeito-mas, testes com a pro-forma fazer isso em (45) abaixo mostra que as instâncias verbais não precisam ser iguais, o que é impossível nas estruturas com que-reportativo, como visto na seção 2.2.1.1.

(45) a. QC: O João viaja amanhã pra Alemanha?

R: Que ele viaja amanhã, talvez ele faça isso.

b. QC: O João submete o artigo amanhã?

R: Que ele submete o artigo amanhã, talvez ele faça isso.

c. QC: O Pedro entrega o trabalho amanhã?

$\mathrm{R}$ : Que ele entrega o trabalho amanhã, talvez ele faça isso.

Como me apontou Andrés Saab (comunicação pessoal) as sentenças em (44) acima são possíveis até com a morfologia verbal diferente, como exemplificado em (46) abaixo, o que corrobora a análise de que não se trata de estruturas com que-reportativo.

(46) QC: O João viaja amanhã pra Alemanha?

$\mathrm{R}$ : Que ele vai viajar, talvez ele faça isso.

Sentenças como as em (44) acima não expressam propriedades reportativas, mas sim propriedades de hesitação por parte do falante. Dessa forma, o bloco iniciado por que dessas estruturas é, na verdade, a repetição do contexto com o intuito do falante de ponderar sobre a resposta.

Uma propriedade das estruturas com que-reportativo é permitir advérbios de atos de fala, como vemos em (47) abaixo.

(47) Que-reportativo 
a. QC: Você sabe se o João comeu o bolo?

R: Sinceramente, que ele comeu o bolo, ele comeu (mas fez careta o tempo todo)

b. QC: A Maria deve dinheiro pra empresa?

R: Francamente, que ela deve dinheiro, ela deve (mas não tem como pagar)

c. QC: O Pedro fez a lição de casa?

R: Sinceramente, que ele fez a lição de casa, ele fez (mas não fez bem feito)

Essa propriedade, porém, não é aceita em estruturas como as em (44) acima, como vemos em (48) abaixo, o que mostra que estamos lidando com estruturas diferentes.

(48) a. QC: O João viaja amanhã pra Alemanha?

R: \#Sinceramente, que ele viaja amanhã, talvez ele viaje.

b. QC: O João submete o artigo amanhã?

R: \#Francamente, que ele submete o artigo amanhã, talvez ele submeta.

c. QC: O Pedro entrega o trabalho amanhã?

R: \#Sinceramente, que ele entrega amanhã, talvez ele entregue.

As estruturas com que-adversativo, quando estão na configuração com os advérbios licenciadores de morfologia de subjuntivo também apresentam morfossintaxe diferente entre os verbos, como vemos em (49) abaixo.

(49) a. QC: O João viaja amanhã pra Alemanha?

R: Não, mas que ele viaja semana que vem, talvez ele viaje.

b. QC: A Maria termina o artigo semana que vem?

R: Não, mas que ela termina até o prazo final, talvez ela termine.

c. QC: O Pedro entrega o trabalho amanhã?

R: Não, mas que ele termina a parte dele amanhã, talvez ele termine.

Aplicando os testes com a pro-forma fazer isso, temos os resultados em (50) abaixo, que mostram que as respostas são pragmaticamente bem formadas.

(50) a. QC: O João viaja amanhã pra Alemanha? 
R: Não, mas que ele viaja semana que vem, talvez ele faça isso.

b. QC: A Maria termina o artigo semana que vem?

$\mathrm{R}$ : Não, mas que ela termina até o prazo final, talvez ela faça isso.

c. QC: O Pedro entrega o trabalho amanhã?

R: Não, mas que ele termina a parte dele amanhã, talvez ele faça isso.

Quanto aos advérbios de atos de fala, temos que as estruturas com queadversativo permitem esses advérbios, enquanto que as estruturas em (49) não permitem, como vemos no contraste entre (51) e (52) abaixo.

(51) a. QC: O João tomou o remédio pra gripe?

R: Não, mas sinceramente, que ele deveria tomar, ele deveria.

b. QC: Você vai pra festa da Maria?

R: Vou, mas francamente, que eu não queria ir, eu não queria.

c. QC: O Pedro fez a lição de casa?

R: Não, mas sinceramente, que ele devia fazer, ele devia.

(52) a. QC: O João viaja amanhã pra Alemanha?

R: *Não, mas sinceramente, que ele viaja semana que vem, talvez ele viaje.

b. QC: A Maria termina o artigo semana que vem?

$\mathrm{R}:$ *Não, mas francamente, que ela termina até o prazo final, talvez ela termine.

c. QC: O Pedro entrega o trabalho amanhã?

$\mathrm{R}$ : *Não, mas sinceramente que ele termina a parte dele amanhã, talvez ele termine.

Dessa forma, vemos que a aparente contra-evidência para a identidade entre os blocos das estruturas com que-reportativo e que-adversativo nos casos de subjuntivos desencadeados pelo advérbio talvez não existe. Na verdade, as estruturas como as em (44) e (49) acima não são de fato estruturas com que-reportativo e que-adversativo.

\subsubsection{Respostas negativas}


Em alguns casos de sentenças negativas com estruturas com que-reportativo, como nos exemplos em (53) abaixo, temos uma falta de identidade entre a negação do contexto e a negação com que-reportativo, como me apontou Jairo Nunes (comunicação pessoal).

(53) a. QC: Eu não acho que a Maria ganha pouco.

R: Que ela não ganha pouco, ela não ganha, mas ela trabalha realmente bastante.

b. QC: Não parece que o João fala muito com os colegas de sala.

R: Que ele não fala muito, ele não fala, mas ele atrapalha a aula mesmo assim.

c. QC: Eu não acho que o Pedro recebe muitos presentes no aniversário.

R: Que ele não recebe, ele não recebe, mas ele não se importa.

O interessante é que através dos testes com a pro-forma fazer isso e com os advérbios de atos de fala, como apresentados em (54) e (55) abaixo, vemos que são de fato estruturas com que-reportativo, se tornando inaceitáveis com a pro-forma fazer isso e permitindo advérbios de atos de fala.

(54) a. QC: Eu não acho que a Maria ganha pouco.

R: *Que ela não ganha pouco, ela não faz isso, mas ela trabalha realmente bastante.

b. QC: Não parece que o João fala muito com os colegas de sala.

R: *Que ele não fala muito, ele não faz isso, mas ele atrapalha a aula mesmo assim.

c. QC: Eu não acho que o Pedro recebe muitos presentes no aniversário.

R: *Que ele não recebe, ele não faz isso, mas ele não se importa.

(55) a. QC: Eu não acho que a Maria ganha pouco.

R: Sinceramente, que ela não ganha pouco, ela não ganha, mas ela trabalha realmente bastante.

b. QC: Não parece que o João fala muito com os colegas de sala.

R: Francamente, que ele não fala muito, ele não fala, mas ele atrapalha a aula mesmo assim. 
c. QC: Eu não acho que o Pedro recebe muitos presentes no aniversário.

R: Sinceramente, que ele não recebe, ele não recebe, mas ele não se importa.

Porém, mesmo os testes em (54) e (55) acima mostrando que são de fato estruturas com que-reportativo, temos que esse fenômeno não é um contra-exemplo. Na verdade, o que temos são estruturas de alçamento de negação (Neg raising), pois sempre envolvem verbos de intenção, como pretender, planejar, querer, ou verbos de julgamento, como achar, dever, avisar, parecer (Klooster 2003). Ao mudarmos para outro tipo de verbo, a resposta em que-reportativo não é adequada, como vemos em (56) abaixo.

(56) a. QC: Eu não questiono que a Maria ganha pouco.

R: \#Que ela não ganha pouco, ela não ganha, mas ela trabalha realmente bastante.

b. QC: Eu não contestei que o João fala muito com os colegas de sala.

R: \#Que ele não fala muito, ele não fala, mas ele atrapalha a aula mesmo assim.

c. QC: Eu não desmenti que o Pedro recebe muitos presentes no aniversário.

R: \#Que ele não recebe, ele não recebe, mas ele não se importa.

Outra característica que mostra que estamos lidando com estruturas de alçamento de negação é o fato das sentenças das QCs terem o mesmo significado estando a negação na oração matriz ou na encaixada, como vemos em (57) abaixo.

(57) a. Eu não acho que a Maria ganha pouco.

a'. Eu acho que a Maria não ganha pouco.

b. Não parece que o João fala muito com os colegas de sala.

b'. Parece que o João não fala com os colegas de sala.

c. Eu não acho que o Pedro recebe muitos presentes no aniversário.

c'. Eu acho que o Pedro não recebe muitos presentes no aniversário.

Dessa forma, temos que não estamos lidando com um contra-exemplo, pois a negação nessas estruturas é gerada na oração encaixada e depois alçada para a oração 
matriz (Fillmore 1963), mantendo o significado negativo também na oração em que foi gerada, como ilustrado em (58) abaixo.

(58) a. Eu não $\mathbf{1}$ acho que a Maria $\mathbf{t}_{\mathbf{1}}$ ganha pouco.

b. Não 1 parece que o João $\mathbf{t}_{\mathbf{1}}$ fala muito com os colegas de sala.

c. Eu não1 acho que o Pedro $\mathbf{t}_{1}$ recebe muitos presentes no aniversário.

Assim, as respostas com que-reportativo em (56) acima não estão divergindo das QCs; as respostas com que-reportativo recuperam a negação no lugar em que esta foi gerada, não sendo um caso de falta de identidade.

\subsection{Conclusão}

Neste capítulo, exploramos as características das construções com quereportativo e que-adversativo com foco nas questões de identidade. Pelos dados apresentados, conclui-se que as estruturas com que-reportativo e que-adversativo são sensíveis à forma morfossintática dos verbos. Em relação ao contexto, como já esperado, as estruturas com que-adversativo, que não reportam obrigatoriamente o contexto, podem variar nos verbos sinônimos.

Três aparentes contra-exemplos para a sensibilidade das estruturas com quereportativo e que-adversativo foram analisados: o caso do presente histórico, em que as respostas com que-reportativo com tempo verbal diferente da QC são possíveis; o caso do modo subjuntivo, em que o verbo e a repetição do verbo nas estruturas com quereportativo e que-adversativo podem ser diferentes e o caso das respostas negativas. Pela análise, vimos que o presente histórico na verdade possui restrições pragmáticas que não permitem respostas em presente histórico se falante e ouvinte não estiverem na mesma perspectiva de passado. Através de exemplos como reconstrução de cena policial, vimos que é a restrição pragmática do presente histórico que não permite a resposta com que-reportativo no mesmo tempo verbal e não uma questão de identidade das estruturas com que-reportativo. A falta de identidade com modo subjuntivo não se aplica pois as estruturas com advérbios desencadeadores de modo subjuntivo não são de fatos estruturas com que-reportativo e que-adversativo, como visto nos testes com a proforma fazer isso e com advérbios de atos de fala. Já o caso das respostas negativas 
diferentes das QCs, vimos pelos testes que são de fato estruturas com que-reportativo, entretanto, as QCs negativas são construções de alçamento de negação. Estas construções têm a negação gerada na oração encaixada e depois movida para a oração matriz, mantendo o significado negativo também no local de origem. Assim, as respostas negativas com que-reportativo estão recuperando esse sentido negativo do local em que a negação foi gerada, não constituindo em um caso de falta de identidade.

O quadro 4 abaixo resume algumas das semelhanças e diferenças encontradas entre as estruturas com que-reportativo e que-adversativo no quesito de identidade.

\section{Quadro 4. Semelhanças e diferenças entre as estruturas em relação a questões de}

\section{identidade}

\begin{tabular}{|c|c|c|c|c|c|}
\hline & $\begin{array}{c}\text { Verbos } \\
\text { sinônimos } \\
\text { (verbos } \\
\text { diferentes entre } \\
\text { QC e verbos das } \\
\text { estruturas) }\end{array}$ & $\begin{array}{c}\text { Possibilidade de } \\
\text { verbos sinônimos } \\
\text { nos dois verbos } \\
\text { presentes nas } \\
\text { estruturas }\end{array}$ & $\begin{array}{c}\text { Morfologia de } \\
\text { tempo verbal } \\
\text { diferente nos dois } \\
\text { verbos das } \\
\text { estruturas }\end{array}$ & $\begin{array}{c}\text { Morfossintaxe } \\
\text { diferente na } \\
\text { presença de } \\
\text { advérbios } \\
\text { licenciadores de } \\
\text { subjuntivo }\end{array}$ & $\begin{array}{l}\text { Possibilidade de não } \\
\text { ter identidade em } \\
\text { traços- } \varphi\end{array}$ \\
\hline $\begin{array}{c}\text { Que- } \\
\text { reportativo }\end{array}$ & $\mathrm{NA \tilde {O }}$ & $\mathrm{NA \tilde {O }}$ & $\mathrm{NA \tilde {O }}$ & $\mathrm{NA \tilde {O }}$ & SIM \\
\hline $\begin{array}{c}\text { Que- } \\
\text { adversativo }\end{array}$ & SIM & NÃO & NÃO & NÃO & SIM \\
\hline
\end{tabular}

Vemos pelo quadro 4 acima que as estruturas com que-reportativo e que-adversativo possuem mais semelhanças do que diferenças quando nos referimos a questões de identidade. 


\section{CAPÍTULO 4: ESTRUTURA INFORMACIONAL}

\section{Introdução}

Neste capítulo analiso as estruturas com que-reportativo e que-adversativo em função de seu estatuto informacional (ver e.g. Rizzi 1997, Zubizarreta 1998, Büring 2000, Lee 2003, Bianchi \& Frascarelli 2010).

\subsection{Características e definições de foco e tópico}

A literatura a respeito de foco e tópico é vasta, mas para a análise das estruturas com que-reportativo e que-adversativo, algumas características e definições específicas de tópico e foco serão fundamentais e, dessa forma, serão apresentadas a seguir.

Segundo Rizzi (1997), foco pode ser o elemento mais à esquerda da sentença, apresenta informação nova, e é definido como o elemento que recebe o acento focal. A estrutura de foco é composta por foco-pressuposição, como exemplificado em (1) abaixo, adaptado de Rizzi (1997:285). Foco é a informação nova e pressuposição é a informação dada contextualmente, informação conhecida entre falante-ouvinte.

(1) [foco YOUR BOOK] [pressuposição you should give t to Paulo] (not mine)

A estrutura de foco está representada em (2) abaixo.

(2) (Rizzi 1997:287)

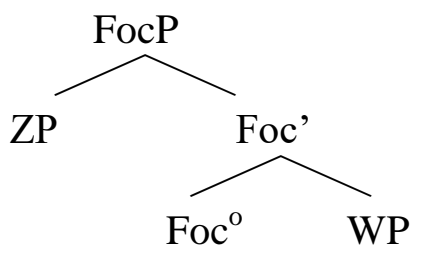

$\mathrm{ZP}=$ focus

$\mathrm{WP}=$ presupposition

A respeito da definição de foco, para as estruturas analisadas nesta pesquisa também será importante a distinção entre foco apresentacional e foco contrastivo de 
Zubizarreta (1998). Nesta divisão, foco apresentacional é definido como a informação nova que recebe proeminência acentual, que pode ser a sentença inteira, como vemos no exemplo em (3a) abaixo, ou um constituinte, como vemos em (3b). Já o foco contrastivo é definido como o constituinte que nega um valor anteriormente estabelecido e introduz um novo valor alternativo presente contextualmente no discurso, como vemos no exemplo em (4) abaixo.

(3) a. Foco apresentacional na sentença inteira

QC: O que aconteceu?

R: [Foco O João comeu o bolo]

b. Foco apresentacional no constituinte

QC: O que o João comeu?

$\mathrm{R}$ : Ele comeu [Foco o bolo]

(4) Foco contrastivo

QC: O João comeu o bolo?

R: Não, ele comeu [Foco a torta].

Tópicos, segundo Rizzi (1997), são caracterizados por serem elementos mais à esquerda na sentença e serem separados por entonação de vírgula, como vemos em (5) abaixo, adaptado de Rizzi (1997:285). Tópicos expressam informação velha, mas que ainda é saliente no discurso em questão e fazem parte da articulação tópico-comentário. O comentário é um tipo de predicado que expressa informação nova.

(5) [tópico Your book,] [comentário you should give t to Paul] (not to Bill)

A estrutura de tópico está representada em (6) abaixo.

(6) (Rizzi 1997:286)

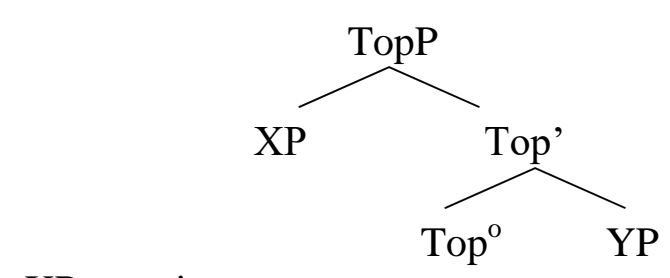

$\mathrm{XP}=$ topic 
$\mathrm{YP}=$ comment

Segundo essa proposta de Rizzi, as estruturas de tópico e foco estão na periferia esquerda da sentença, assim como as projeções de força ilocucionária, compondo o sistema de CP. A estrutura completa dessas projeções está representada em (7) abaixo.

(7) Rizzi (1997:297)

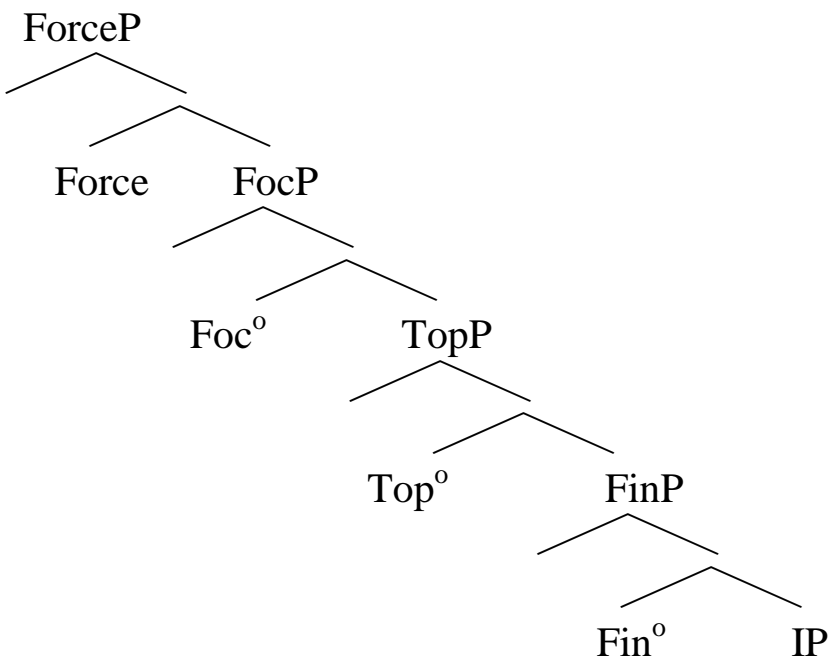

O tópico clássico é aquele que retoma contexto, demarca o assunto ou introduz um novo assunto, chamado tópico conversacional (aboutness topic na nomenclatura de Bianchi \& Frascarelli 2010). Em oposição a este está o tópico contrastivo que, como descreve Büring (2000), não retoma literalmente o contexto, mas indica uma estratégia discursiva que responde a subperguntas da pergunta em discussão, como vemos na árvore discursiva em (8) abaixo.

(8) Büring (2000: 4)

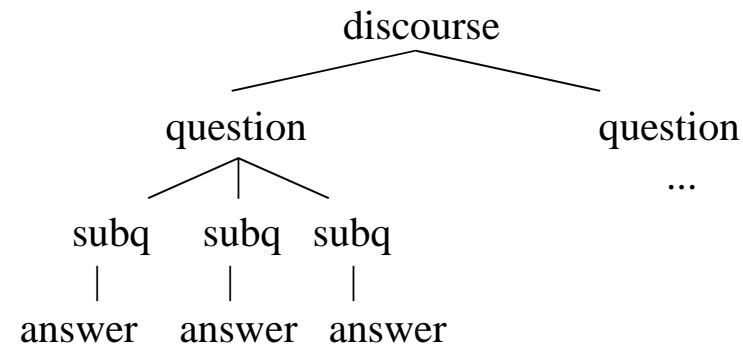


O esquema em (8) acima mostra que a pergunta em discussão possui subperguntas e as respostas para essas subperguntas é o que Büring classifica como tópico contrastivo, pois são contrastes à pergunta em discussão, porém não são informações totalmente novas, as respostas retomam o subconjunto de perguntas. Para Büring, as perguntas em discussão devem ser perguntas-QU para ter o valor contrastivo. Os exemplos em (9)(10) abaixo ilustram o esquema apresentado em (8).

(9) Büring (2000: 11, adaptado)

What did the pop stars wear?

what did the female pop stars wear?

The female wore caftans what did the male pop stars wear?

The male wore suits

Qual esporte os alunos praticaram?

Qual esporte as meninas praticaram?

As meninas praticaram vôlei
Qual esporte os meninos praticaram?<smiles>C=C</smiles>

Os meninos praticaram futebol

Em uma reformulação da proposta de Büring, Lee (2003) utiliza tópico contrastivo como estratégia discursiva também para perguntas-sim/não, alegando que perguntas-sim/não também possuem subperguntas como alternativas, como vemos em (11) abaixo.

(11) Lee (2003: 2, adaptado)

a. Do you have money?

R: I have coins.

Subperguntas: Do you have coins?

Do you have bills?

Em (11) acima, vemos que I have coins é uma resposta pragmaticamente boa à pergunta do you have money?, porque ela responde à subpergunta do you have coins?, mostrando que a estratégia de tópico contrastivo de responder a subperguntas é possível também 
em perguntas-sim/não. Com a pergunta e as subperguntas em (11) acima é perfeitamente possível elaborar uma árvore discursiva, como vemos em (12) abaixo.

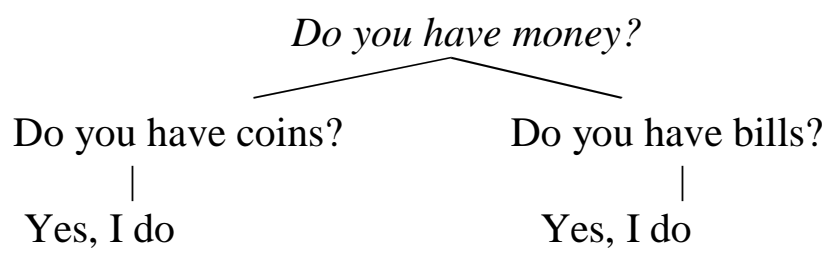

A respeito das posições sintáticas dos tópicos, Bianchi \& Frascarelli (2010), analisando curvas entoacionais do italiano e alemão, argumentam que há uma hierarquia sintática entre tópicos conversacionais e tópicos contrastivos, como vemos representado em (13) abaixo.

(13) Bianchi \& Frascarelli (2010: 59, adaptado)

$$
\text { [ShiftP A-Topic [ContrP C-Topic... [ IP ...]]] }
$$

Vemos em (13) acima que o tópico contrastivo (C-Topic), que contrasta com a pergunta em discussão, é mais baixo do que o tópico conversacional (A-Topic), que retoma o contexto recentemente introduzido ou introduz um novo assunto.

Segundo Bianchi \& Frascarelli, os tópicos conversacionais são assinalados por um aumento na curva F0, apresentando uma curva entoacional elevada, o que só ocorre na posição mais alta da periferia esquerda. Os tópicos contrastivos não apresentam curvas entoacionais tão altas, ocupando posições mais baixas ${ }^{10}$. Como ilustração desses fenômenos, temos a entrevista de uma aluna em (14) e a análise da sentença em que os tópicos estão presentes em (15) abaixo.

(14) Bianchi \& Frascarelli (2010: 60)

Sì nel primo per esempio c'era diciamo a sinistra dello schermo la traduzione in italiano c'erano tutti $i$ vari diciamo sistemi per avere informazioni in più e io lì non l'avevo capito insomma... invece nel terzo caso c'era di nuovo questa cosa e io mi sono trovata molto più diciamo tranquilla a mio ágio perché finalmente avevo scoperto come funzionava.

'Yes, in the first example there was, on the left of the screen, the Italian translation,

\footnotetext{
${ }^{10}$ Para um detalhamento da proposta ver Frascarelli \& Hinterhölzl (2007) e Bianchi \& Frascarelli (2010).
} 
there were all the different ways to get more information and, in short, I did not understand it there - on the contrary in the third example there was again this thing and in that occasion I was already much more self-confident, because finally I discovered how it worked'

(15) Bianchi \& Frascarelli (2010: 60)

a. io, lì non l' avevo capito, insomma.

I there not it.CL had.1SG understand.PART in short

'In short, I did not understand it at that point.'

b.

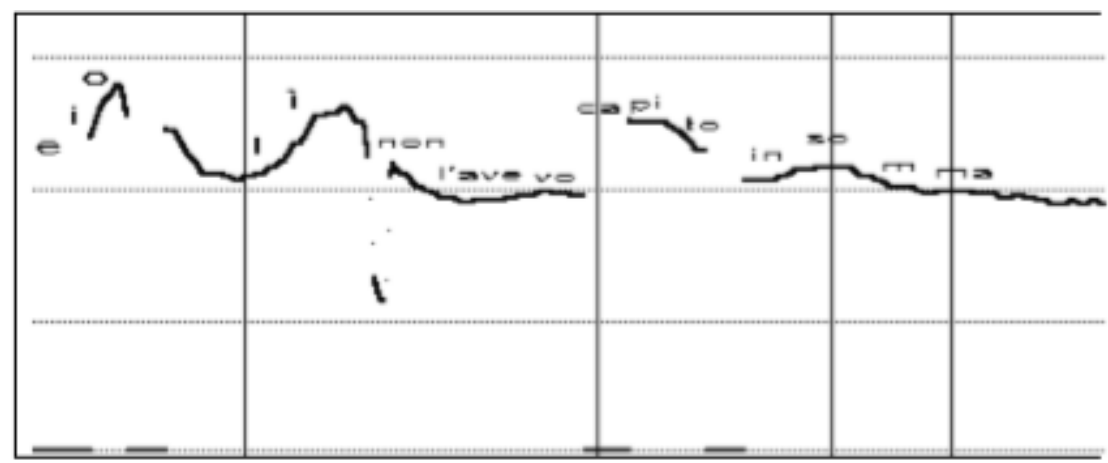

A sentença em (15a) acima possui um tópico conversacional (io), em que o falante está mudando o tópico sobre a descrição de um programa de linguagem para inserir sua opinião, e um tópico contrastivo ( $l i$ 'primeiro'), em que o falante está contrastando esse primeiro exercício com o terceiro (terzo 'terceiro'). Na figura em (15b) acima, podemos observar que as curvas entoacionais de io e lì são diferentes, justificando assim suas diferentes classificações.

De posse dessas definições, as próximas seções procuram analisar se os constituintes das estruturas com que-reportativo e que-adversativo são tópicos ou focos.

\subsection{Estatuto informacional}

\subsubsection{Que-reportativo}

As estruturas com que-reportativo são compostas por dois blocos, um iniciado pelo que e outro bloco envolvendo uma oração, que pode conter apenas uma repetição 
do verbo anterior. À primeira vista, esses blocos parecem ter estrutura informacional diferente, restando saber se apresentam a estrutura tópico-comentário ou focopressuposição, como vimos em 4.1 acima.

\subsubsection{Testes para foco}

Para testar se os constituintes de estruturas com que-reportativos são focos, utilizarei os testes de pergunta e resposta de Zubizarreta (1998). Os testes são para foco apresentacional, em que o constituinte focalizado responde ao constituinte interrogativo da questão contextualizadora, e para foco contrastivo, em que um valor estabelecido na questão contextualizadora é negado e a resposta introduz um novo valor no discurso.

Considere os testes para foco apresentacional em relação ao primeiro termo das estruturas com que-reportativo em (16) abaixo.

(16) a. QC: O que aconteceu?

R: \# [Foco Que o João comeu o bolo], ele comeu (mas..)

b. QC: O que o João fez?

R:\# Que ele [Foco comeu o bolo], ele comeu (mas...)

c. QC: O que o João fez com o bolo?

R: \# Que ele [Foco comeu] o bolo, ele comeu (mas...)

d. QC: O que o João comeu?

R: \# Que ele comeu [Foco o bolo], ele comeu (mas...)

Em (16a) o foco recai sobre o primeiro termo inteiro da sentença, em (16b) sobre o VP, em (16c) somente sobre o verbo e em (16d) sobre o argumento interno do verbo. Todas as quatro sentenças, não importando onde o foco recaia, são inaceitáveis. Os testes indicam, portanto, que não há foco apresentacional dentro no primeiro termo das construções com que-reportativo.

Considere agora o teste de foco apresentacional para o segundo termo das estruturas com que-reportativo em (17) abaixo.

(17) a. QC: O que o João fez?

R: \# Que ele comeu o bolo, [Foco ele comeu] (mas..) 
b. QC: O que o João fez com o bolo?

R: \# Que ele comeu o bolo, ele [Foco comeu] (mas...)

c. QC: O que o João comeu?

R: \# Que ele comeu, ele comeu [Foco o bolo] (mas...)

Vemos em (17) acima que a presença de foco apresentacional no segundo termo das estruturas com que-reportativo não é pragmaticamente bem formada devido à necessidade de repetição do conteúdo do primeiro termo, não podendo apresentar informação nova, como visto na seção 2.2.1.6.

Para os testes de foco contrastivo no primeiro termo, a previsão é que as estruturas não devem ser compatíveis com foco contrastivo devido a sua propriedade de retomar o contexto anterior, não apresentando informação nova. Os testes em (18) abaixo confirmam essa previsão.

(18) a. QC: O Pedro alugou a casa?

R: \#Que ele [Foco vendeu o apartamento], ele vendeu (mas...)

b. QC: O Pedro aluga casa?

R: \# Que ele aluga [Foco apartamento], ele aluga (mas...)

Para os testes de foco contrastivo no segundo termo, considere os dados em (19) abaixo.

(19) a. QC: O Pedro alugou a casa?

$\mathrm{R}: *$ Que ele alugou a casa, ele [Foco vendeu o apartamento], (mas...)

b. QC: O Pedro aluga casa?

R: *Que ele aluga casa, ele aluga [Foco apartamento], (mas...)

Vemos em (19) acima, que as sentenças são agramaticais se inserirmos um foco contrastivo no segundo termo negando um valor anteriormente estabelecido. Isso se deve também porque as estruturas com que-reportativo têm de ter a repetição do constituinte verbal do primeiro bloco, como vimos nas seções 2.2.1.6 e 2.2.1.8.

Portanto, tanto no caso do primeiro quanto do segundo termo, as sentenças em (16)-(19) acima são inaceitáveis se contiverem foco apresentacional ou foco contrastivo. 


\subsubsection{Características de tópico}

Analisando uma sentença com que-reportativo como em (20) abaixo e assumindo Rizzi (1997), vemos que a estrutura possui características de tópico: o primeiro termo que ele varreu é uma informação velha que reporta o discurso anterior, está na periferia esquerda da sentença e é separado por entonação de vírgula.

(20) QC: O Pedro varreu a casa ontem?

R: Que ele varreu, ele varreu (mas...)

O segundo termo da estrutura não parece inicialmente apresentar a característica do comentário de ser informação nova. Porém, esse segundo termo é a confirmação do que é apresentado no primeiro termo, sendo, portanto, a informação relevante.

Assim, vemos que as estruturas com que-reportativo não apresentam foco mas parecem apresentar articulação de tópico-comentário, como vemos em (21) abaixo. Pela característica de estabelecer o tópico da conversa retomando o contexto, temos que o tópico das estruturas com que-reportativo, seguindo a nomenclatura de Bianchi \& Frascarelli (2010), é um tópico conversacional.

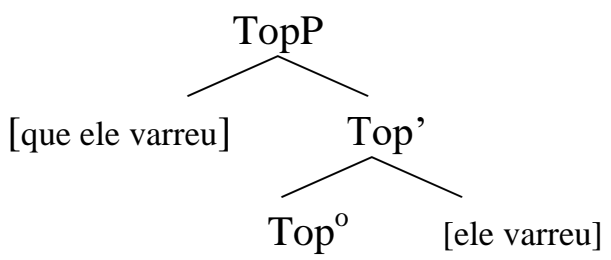

\subsubsection{Que-adversativo}

As construções com que-adversativo são compostas por três blocos: um bloco que responde à questão contextualizadora, um bloco iniciado pelo conjunção mas e um bloco envolvendo uma oração, que pode conter apenas a repetição do verbo anterior. Assim como com as estruturas com que-reportativo, esses blocos parecem ter estatutos informacionais diferentes, o que será analisado nesta seção. 


\subsubsection{Testes para foco}

Os testes para foco com as construções com que-reportativo mostrados na seção 4.2.2 também serão aplicados nas estruturas com que-adversativo. Como foco apresentacional é a parte que responde o elemento interrogativo da questão contextualizadora, temos que as estruturas com que-adversativo vão apresentar foco apresentacional em seu primeiro termo, já que é o primeiro termo que responderá ao elemento interrogativo da questão contextualizadora, como vemos em (22)-(25) abaixo.

(22) QC: O que aconteceu?

R: Eu não sei, mas que o João tava com cara de culpado, ele tava.

(23) QC: O que o João fez?

R: Eu não sei, mas que ele saiu correndo quando a polícia chegou, ele saiu.

(24) QC: Você sabe o que aconteceu com o João?

R: Sei, mas que eu não posso contar, eu não posso.

(25) QC: Você viu o que aconteceu?

R: Vi, mas que eu não devia ter visto, não devia.

Em (22)-(23) acima, vemos que o primeiro bloco da resposta eu não sei responde à pergunta da QC e o segundo bloco introduz uma resposta a uma subpergunta como "o João parecia culpado?”. Em (24) acima, temos que o primeiro bloco sei responde à pergunta da QC e o segundo bloco introduz uma resposta a uma subpergunta como “você pode/vai contar o que aconteceu?". Em (25) acima, também temos o primeiro bloco vi respondendo à pergunta da $\mathrm{QC}$ e o segundo bloco introduzindo uma resposta a uma subpergunta como "você deveria ter visto o que aconteceu?". Assim, vemos que o segundo bloco parece estar respondendo a subperguntas implícitas relacionadas à pergunta da QC, não podendo ser instâncias de foco apresentacional.

Para os testes de foco contrastivo, temos que as estruturas não são compatíveis, pois o primeiro termo é que vai confirmar ou negar os valores propostos pela $\mathrm{QC}$, como vemos em (26). 
(26) a. QC: O Paulo vende celular na loja.

R: [Contraste Não], mas que ele conserta celular, ele conserta.

b. QC: A Maria agora é vegetariana.

R: \#É, mas [Contraste que a Fátima come peixe], ela come.

c. QC: A Maria agora é vegetariana.

R: \#É, mas que ela [Contraste come peixe], ela come.

Em (26a) acima vemos que o primeiro bloco quando nega o valor proposto pela QC pode ser contrastivo. Já os exemplos em (26b-c) mostram que quando o contraste está em outros blocos, as sentenças não são pragmaticamente aceitáveis, pois o primeiro termo já está confirmando o valor proposto na QC.

Para contraste no terceiro termo, temos os testes em (27) abaixo, que mostram que não é gramatical o terceiro termo apresentar contraste, já que este termo repete o segundo.

(27) a. QC: A Maria é vegetariana?

$\mathrm{R}$ : *É, mas que ela come peixe, [Contraste ela come frango].

b. QC: O Pedro alugou a casa?

R: *Não, mas que ele vendeu o apartamento, [Contraste ele vendeu o estúdio].

c. QC: O Pedro conserta celular?

R: *Não, mas que ele conserta computador, [Contraste ele conserta tablet].

A partir dos testes, vemos que as estruturas com que-adversativo não podem apresentar foco apresentacional (ver (22)-(25) acima) e também não podem apresentar foco contrastivo (ver (26) e (27) acima).

\subsubsection{Características de tópico}

O segundo e terceiro bloco das estruturas com que-adversativo possuem algumas das mesmas características de tópico das estruturas com que-reportativo: estar na periferia esquerda, ser separado por entonação de vírgula e parecem ter uma articulação 
de tópico-comentário. A articulação de tópico-comentário está representada abaixo em (28).

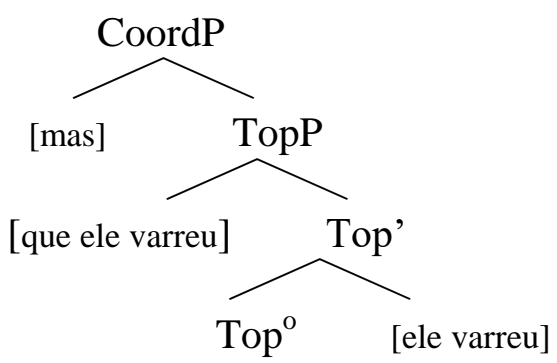

Vemos em (28) que assim como nas estruturas com que-reportativo, o comentário apresenta informação relevante pois confirma o que foi dito no bloco anterior. Entretanto, temos que o segundo bloco das estruturas com que-adversativo não possui a característica de reportar informação velha, já que esse constituinte pode veicular informação nova, como mostra (29) abaixo.

(29) a. QC: A Maria faz doces pra vender?

R: Não, mas que ela faz salgadinhos maravilhosos, ela faz.

b. QC: O Pedro vai pra palestra amanhã?

R: Vai, mas que ele preferia ficar em casa, ele preferia.

c. QC: A Rita teve reunião com o chefe do departamento?

R: Não, mas que ela marcou a reunião, ela marcou.

Porém, temos que a informação nova das estruturas com que-adversativo é selecionada de um conjunto limitado de subperguntas e não uma informação totalmente nova no contexto discursivo, como exemplificado em (30)-(35) abaixo. Esse conjunto de subperguntas é uma característica dos tópicos contrastivos, que, segundo Büring (2000) e Lee (2003), como vimos na seção 4.1, indicam uma estratégia que não responde completamente a uma pergunta, mas responde a subperguntas da pergunta em discussão. Dessa forma, os tópicos contrastivos não apresentam informações que não possam estar nesse conjunto de subperguntas.

(30) QC: A Maria é vegetariana?

a. É, mas que ela come peixe, ela come. 
b. \#É, mas que ela namora carnívoros, ela namora.

Em (30a) acima temos uma resposta aceitável, pois comer peixe é a resposta a uma das subperguntas da pergunta a respeito de ser vegetariano, já que inclui as subperguntas listadas em (31) abaixo.

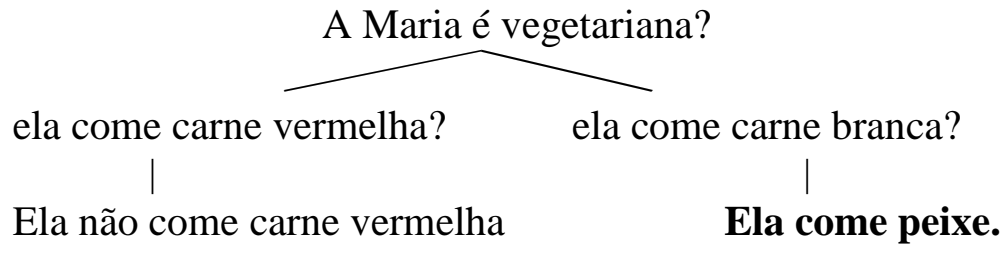

Porém, (30b) acima é pragmaticamente inaceitável por ser uma informação totalmente nova que não entra como resposta a nenhuma subpergunta pragmaticamente associada à pergunta principal, como mostra (31) acima.

Em (32a) abaixo, a resposta é aceitável porque preferir ficar em casa é uma resposta à pergunta em discussão sobre ir pra festa, enquanto que não ir pra aula em (32b) abaixo não está dentro das opções das subperguntas pragmaticamente associadas à pergunta principal, como vemos nas subperguntas listadas em (33) abaixo.

(32) QC: O Pedro vai pra festa amanhã?

a. Vai, mas que ele preferia ficar em casa, ele preferia.

b. \#Vai, mas que ele não vai pra aula, ele não vai.

$$
\text { O Pedro vai pra festa amanhã? }
$$

o Pedro prefere ficar em casa? o Pedro tem compromisso no horário da festa?

Ele prefere ficar em casa $\quad$ Ele não tem compromisso.

O mesmo ocorre com (34a) abaixo, que é uma resposta aceitável, já que ter dinheiro pra comprar é uma resposta à subperguntas da aquisição de um bem material, como vemos em (35) abaixo, enquanto outra pessoa possuir um livro em (34b) abaixo não é uma resposta a nenhuma subpergunta e torna a resposta pragmaticamente inaceitável.

(34) QC: A Rita comprou o livro importado? 
a. Não, mas que ela tem dinheiro pra comprar, ela tem.

b. \#Não, mas que o namorado dela tem livro importado, ele tem.

A Rita comprou o livro importado?

ela tem dinheiro pra comprar o livro?

Ela tem dinheiro

ela tem disponibilidade pra comprar o livro?

Ela tem disponibilidade.

Os dados e subperguntas apresentados em (30)-(35) acima permitem, portanto, classificar o CP após a conjunção mas como um tópico contrastivo, constituindo uma alternativa de resposta à pergunta em discussão. Na próxima seção será discutido como esse tópico contrastivo é gerado.

\subsection{Tópicos: movidos ou gerados na base?}

\subsubsection{Que-reportativo}

Contextos de ilha sintática são testes clássicos para movimento, já que é impossível extrair constituintes de dentro de ilhas. Repetindo os testes da seção 2.2.10, em (36)-(38) abaixo temos contextos de ilha sintática para testar se o tópico inicial foi gerado por movimento ou não.

(36) Oração relativa ${ }^{11}$

\footnotetext{
${ }^{11}$ Uma observação feita por Esmeralda Negrão (comunicação pessoal) é que essas estruturas poderiam não ser relativas verdadeiras, mas sim pseudo-relativas, as quais permitem extrações, como os exemplos em (i) abaixo (com os julgamentos da autora).

(i) Negrão (2000: 155-156)

a. Que animais $s_{1}$ o diretor do Zoo disse que a comida 2 que $\mathrm{t}_{1}$ comeram $\mathrm{t}_{2}$ estava estragada?

b. Que cozinheira $a_{2}$ a comida que $_{2}$ fez $t_{1}$ matou os animais?

c. Que rapaz 1 a comissão premiou o conto ${ }_{2}$ que $t_{1}$ escreveu $t_{2}$ ?
}

Segundo a análise de Negrão (2000), pseudo-relativas possuem a característica de serem parafraseadas por sentenças existenciais contendo uma relativa em posição final, como vemos nas paráfrases em (ii) abaixo com os julgamentos de gramaticalidade da autora. 
a. QC: O João vende carro?

R: Que ele vende carro, [eu conheço uma pessoa que disse que ele vende].

b. QC: A Maria devolveu o livro da biblioteca?

R: Que ela devolveu o livro, [eu encontrei com um aluno que falou que ela devolveu].

c. QC: O Pedro fez a lição de casa?

R: Que ele fez a lição de casa, [eu falei com a professora que disse que ele fez]

(37) Oração com estruturas coordenadas

a. QC: O Pedro vende carro?

$\mathrm{R}: *$ Que ele vende carro, ele vende e aluga.

b. QC: A Rita faz ginástica nos fins de semana?

R: *Que ela faz ginástica, ela faz e anda de bicicleta.

c. QC: A Maria faz doces pra vender?

$\mathrm{R}: *$ Que ela faz doces, ela faz e vende.

(38) Oração com adjunto

a. QC: A Maria terminou com o Pedro?

(ii) Negrão (2000: 157)

a. Tem uns animais que a comida que comeram estava estragada.

b. Tem uma cozinheira que a comida que fez matou os animais.

c. Tem um rapaz que a comissão premiou o conto que escreveu.

Porém, no caso das estruturas com que-reportativo, as sentenças não podem ser parafraseadas por sentenças existenciais com uma relativa no final, pois o sujeito da relativa final retomará o sujeito da relativa que a precede, mudando o significado das sentenças, como vemos comparando (36) com (iii) abaixo.

(iii) a. QC: O João 1 vende carro?

R: Tem um amigo meu $\mathbf{m}_{2}$ que $\boldsymbol{e}_{2}$ disse que $\boldsymbol{e}_{* 1 / 2}$ vende.

b. QC: A Maria ${ }_{1}$ devolveu o livro da biblioteca?

R: Tem um aluno 2 que eu encontrei que $\boldsymbol{e}_{2}$ falou que $\boldsymbol{e}_{*_{1 / 2}}$ devolveu o livro.

c. QC: O Pedro fez a lição de casa?

R: Tem uma professora ${ }_{2}$ que eu acho que $\boldsymbol{e}_{2}$ disse que $\boldsymbol{e}_{* 1 / 2}$ fez a lição. 
$\mathrm{R}: *$ Que ela terminou, ela ficou com peso na consciência [depois que terminou]

b. QC: O João vendeu o carro?

$\mathrm{R}: *$ Que ele vendeu o carro, ele teve o maior prejuízo [depois que ele vendeu]

c. QC: O João limpou o apartamento?

R: *Que ele limpou o apartamento, ele deixou tudo brilhando [depois que ele limpou].

À primeira vista, os resultados em (36)-(38) são conflitantes, permitindo a extração em (36) e não permitindo em (37) e (38). Inspecionando melhor, as sentenças aceitáveis em (36) não são de fato construções com que-reportativo, já que não desencadeiam o efeito-mas, que, como vimos na seção 2.2.1.2, é desencadeado nas construções com que-reportativo "canônicas". As estruturas em (36), na verdade, parecem envolver um CP tópico gerado na base, que retoma o contexto anterior com uma interpretação de hesitação ou dúvida.

Uma evidência independente é que a repetição verbal nas construções como em (36) acima não precisa ser idêntica, pode ocorrer com a pro-forma fazer isso e até mesmo com outro tempo verbal, como vemos em (39) abaixo, o que mostra que não estamos lidando com estruturas com que-reportativo.

\section{(39) a. QC: O João vende carro?}

R1: Que ele vende carro, [eu conheço uma pessoa que disse que ele faz isso na internet].

R2: Que ele vende carro, [eu conheço uma pessoa que disse que ele aluga carro].

b. QC: A Maria devolveu o livro da biblioteca?

R1: Que ela devolveu o livro, [eu encontrei com um aluno que disse que ela fez isso ontem].

R2: Que ela devolveu o livro, [eu conversei com o bibliotecário que disse que ela ia fazer isso ontem].

c. QC: O Pedro fez a lição de casa?

R: Que ele fez a lição de casa, [eu falei com a professora que disse que ele ia fazer] 
Outra evidência de que são construções diferentes é o contraste em (40) e (41) abaixo, em que estruturas com que-reportativo em (40) aceitam advérbios de ato de fala como sinceramente e francamente no início da sentença, enquanto as estruturas relativas em (41) não.

(40) a. QC: Você sabe se o João comeu o bolo?

R: Sinceramente, que ele comeu o bolo, ele comeu (mas fez careta o tempo todo)

b. QC: A Maria deve dinheiro pra empresa?

R: Francamente, que ela deve dinheiro, ela deve (mas não tem como pagar)

c. QC: O João fez a lição de casa?

R: Sinceramente, que ele fez a lição de casa, ele fez (mas não fez bem feito)

(41) a. QC: O João vende carro?

R: ?*Sinceramente, que ele vende carro, eu conheço uma pessoa que disse que ele vende.

b. QC: A Maria devolveu o livro da biblioteca?

R: ?*Francamente, que ela devolveu o livro, eu encontrei com um aluno que falou que ela devolveu.

c. QC: O Pedro fez a lição de casa?

$\mathrm{R}$ : ?*Sinceramente, que ele fez a lição de casa, eu falei com a professora que disse que ele fez.

Dessa forma, vemos que as estruturas em (36) acima não são, de fato, estruturas com que-reportativo. Quando temos estruturas com que-reportativo verdadeiras, como nos casos de (37) e (38) acima, as sentenças são agramaticais. Assim, uma vez que a aparente inconsistência é resolvida, a conclusão é que a derivação de construções com $q u e$-reportativo envolve movimento do primeiro termo, como esquematizado em (42), pois exibe efeitos de ilha sintática.

$$
\left[\text { TopP } \mathrm{CP}_{\mathrm{i}}\left[\mathrm{Top}, \mathrm{Top}\left[\ldots t_{\mathrm{i}} \ldots\right]\right]\right]
$$


A questão que se coloca é de onde partiria o movimento. O contraste em (43) e (44) abaixo mostra que não há posição para o $\mathrm{CP}$ movido ser gerado como argumento nas construções com que-reportativo.

(43) a. Que ele comeu o bolo, ele comeu (mas...)

b. Que ele vendeu o carro, eu acho que ele vendeu.

(44) a. *Ele comeu, que ele comeu o bolo.

b. *Eu acho que ele vendeu, que ele vendeu o carro.

Minha sugestão é que esse tópico poderia ser gerado na periferia esquerda do $v \mathrm{P}$ matriz (ver e.g. Belletti 2004 e Lacerda 2015) e depois se moveria para a periferia esquerda da sentença. Porém, deixo para pesquisas futuras a determinação da posição exata na periferia onde esse constituinte pode ser gerado, bem como uma explicação para a obrigatoriedade do movimento para a periferia mais alta.

\subsubsection{Que-adversativo}

Os dados em (45)-(47) para estruturas com que-adversativo mostram o mesmo padrão visto anteriormente nas construções com que-reportativo, ou seja, as orações relativas são gramaticais enquanto as orações com estruturas coordenadas e com adjunto são agramaticais.

(45) Oração relativa

a. QC: O João vende carro?

R: Não, mas que o Pedro vende, [eu conheço uma pessoa que disse que ele vende].

b. QC: A Maria vai pra festa junina da escola?

R: Não, mas que ela queria ir, [eu encontrei com um aluno que disse que ela queria].

c. QC: O Pedro fez a lição de casa?

R: Não, mas que ele vai fazer amanhã, [eu falei com a professora que disse que ele vai fazer] 
(46) Oração com estruturas coordenadas

a. QC: O Pedro vende carro?

$\mathrm{R}$ : *Não, mas que ele vende moto, ele vende e aluga.

b. QC: A Rita faz ginástica nos fins de semana?

$\mathrm{R}$ : *Não, mas que ela corre no parque, ela corre e anda de bicicleta.

c. QC: A Maria faz doces pra vender?

R: *Não, mas que ela faz salgados, ela faz e vende.

(47) Oração com adjunto

a. QC: A Maria terminou com o Pedro?

R: *Não, mas que ela traiu ele, ela ficou com peso na consciência [depois que ela traiu].

b. QC: O João vendeu a casa?

$\mathrm{R}$ : *Não, mas que ele reformou a casa, ele teve o maior prejuízo [depois que ele reformou].

c. QC: O João limpou o apartamento?

$\mathrm{R}:$ *Não, mas que ele sujou, ele deu uma desculpa [depois que ele sujou].

Assim como que-reportativo, os resultados em (45)-(47) acima são aparentemente conflitantes, já que temos efeitos de ilha em (46) e (47), mas não em (45). Seguindo a análise feita para que-reportativo, as estruturas relativas em (45) não são de fato estruturas com que-adversativo, pois também aceitam a pro-forma fazer isso, como mostra (48) abaixo.

(48) a. QC: O João vende carro?

R: Não, mas que o Pedro vende, [eu tenho uma amiga que disse que ele faz isso na internet].

b. QC: A Maria comprou os doces?

R1: Não, mas que ela encomendou, [eu encontrei com o padeiro que disse que ela fez isso ontem].

c. QC: O Pedro ligou pra Maria?

R: Não, mas que ele vai ligar amanhã, [eu falei com um amigo dele que disse 
que ele vai fazer isso amanhã]

Vemos em (48) que o segundo constituinte verbal nas construções como em (45) acima não precisa ser idêntico. Esse constituinte verbal pode ocorrer com a pro-forma fazer isso, o que mostra que não estamos lidando com estruturas com que-adversativo.

Outra evidência é o contraste entre (49) e (50) abaixo, em que as estruturas com que-adversativo em (49), assim como as estruturas com que-reportativo, admitem advérbios de atos de fala, enquanto as estruturas relativas em (50) não aceitam.

(49) a. QC: O João tomou o remédio pra gripe?

R: Não, mas sinceramente, que ele deveria tomar, ele deveria.

b. QC: Você vai pra festa da Maria?

R: Vou, mas francamente, que eu não queria ir, eu não queria.

c. QC: O Pedro fez a lição de casa?

R: Não, mas sinceramente, que ele deveria fazer, ele deveria.

(50) a. QC: O João tomou os suplementos alimentares?

R: ?*Não, mas, sinceramente, que ele deveria tomar, eu conversei com uma nutricionista que disse que ele deveria.

b. QC: A Maria vai pra festa junina da escola?

$\mathrm{R}$ : *Vai, mas, francamente, que ela não queria ir, eu conversei com um aluno que disse que ela não queria.

c. QC: O Pedro fez a lição de casa?

R: *Não, mas, sinceramente, que ele devia fazer logo, eu falei com uma professora que disse que ele devia.

Dessa forma, vemos que, quando temos as estruturas com que-adversativo, como nos casos de (46) e (47) acima, as sentenças são agramaticais, o que indica que o tópico contrastivo é derivado por movimento. Da mesma forma que com que-reportativo, não há posição onde o tópico contrastivo poderia ser gerado na estrutura argumental das construções com que-adversativo, como vemos no contraste entre (51) e (52) abaixo.

(51) a. Não, mas que ele comeu o bolo, ele comeu. 
b. Não, mas que ele vendeu o carro, eu acho que ele vendeu.

(52) a. *Não, mas ele comeu, que ele comeu o bolo.

b. *Não, mas eu acho que ele vendeu, que ele vendeu o carro.

A sugestão para a posição em que o tópico contrastivo seria gerado é a mesma das estruturas com que-reportativo: periferia esquerda de $v \mathrm{P}$. Assumindo a hierarquia de tópicos de Bianchi \& Frascarelli (2010) apresentada na seção 4.1, temos a estrutura com que-adversativo e tópico contrastivo esquematizada em (53) abaixo. Deixo para pesquisas futuras a exata posição em que o tópico contrastivo é gerado, bem como a motivação para este movimento.

(53) [CoordP [Coord mas [TopP [Top' Top [TopContrP $\mathrm{CP}_{\mathrm{i}}\left[\right.$ TopContr' TopContr $\left.\left.\left.\left.\left.\left[\ldots t_{\mathrm{i}} \ldots\right]\right]\right]\right]\right]\right]$

\subsection{Conclusão}

Neste capítulo, foram explorados dois pontos: o estatuto informacional dos blocos iniciados por que das estruturas com que-reportativo e com que-adversativo, através das características e definições de Rizzi (1997), Zubizarreta (1998), Büring (2000) e Bianchi \& Frascarelli (2010), e se esses blocos são derivados por movimento ou gerados na base. Os resultados obtidos sobre o estatuto informacional são:

- Que-reportativo: os testes de foco (Zubizarreta 1998) demonstraram que essas estruturas não apresentam foco apresentacional nem foco contrastivo em nenhum de seus blocos. O primeiro bloco das estruturas possui características de tópico (Rizzi 1997), como apresentar informação velha, estar na periferia esquerda, ser separado por entoação de vírgula e, por estabelecerem o tópico da conversa, conclui-se que são tópicos conversacionais.

- Que-adversativo: os testes de foco (Zubizarreta 1998) demonstraram que essas estruturas também não apresentam foco apresentacional nem foco contrastivo. Vimos também que o segundo bloco possui características de tópico (Rizzi 1997) como estar mais à esquerda e ser separado por entoação de vírgula, 
porém, não apresenta informação velha. Entretanto, a informação nova veiculada pelo segundo bloco não é informação totalmente nova, mas um contraste selecionado de respostas possíveis para subperguntas relacionadas à pergunta em discussão (Büring 2000, Lee 2003), concluindo-se, assim, que são tópicos contrastivos.

Após os constituintes serem definidos como tópicos, o segundo ponto explorado foi se esses tópicos são gerados por movimento ou na base. Através dos testes de ilha sintática (estruturas coordenadas e orações de adjunto), pôde-se ver que o tópico conversacional das estruturas com que-reportativo e o tópico contrastivo das estruturas com que-adversativo são derivados por movimento, pois apresentaram efeito de ilha sintática. Uma análise mais detalhada da fonte e da motivação do movimento ficará para pesquisas futuras. 


\section{CAPÍTULO 5: EFEITO-MAS NAS ESTRUTURAS COM $Q U E$-REPORTATIVO}

\section{Introdução}

Neste capítulo, são apresentadas as propostas de Bastos (2001), Bastos-Gee (2009) e Vicente (2007) para explicar o efeito-mas e seu cancelamento. Depois analiso a falta de obrigatoriedade do efeito-mas nas estruturas com que-reportativo como uma consequência da Máxima de Quantidade de Grice (1975), apoiando a análise de Bastos/ Bastos-Gee. Por fim, apresento brevemente a alternância entre os diferentes itens lexicais que são possíveis na coordenada adversativa das estruturas com quereportativo.

\subsection{Efeito-mas em Bastos (2001) /Bastos-Gee (2009) e Vicente (2007)}

As construções com que-reportativo geram o efeito-mas proposto por Bastos (2001)/ Bastos-Gee (2009) e apresentado na seção 2.2.1.2. As sentenças com efeito-mas geram uma expectativa que dá a impressão de que a sentença está incompleta. Esta expectativa é representada por uma sentença coordenada adversativa, que pode ficar implícita ou não. O efeito-mas nas estruturas de topicalização de infinitivos do tipo $2 \mathrm{e}$ do tipo 3 estudadas por Bastos está exemplificado em (1) abaixo.

(1) a. Tipo 2

Lavar o carro, o João lavou (mas...)

b. Tipo 3

Lavar carro, o João lava (mas...)

Como visto na seção 2.2.1.2, efeito-mas pode ser cancelado se um elemento estiver focalizado, como exemplificado abaixo em (2)-(3).

(2) Tipo 2 (Bastos 2001: 59)
a. Com efeito-mas
Vender a casa, o João vendeu (mas...)
b. Sem efeito-mas 
Vender a casa, foi [Foco O JOÃO] que vendeu.

Vender a casa, [Foco O JOÃO] vendeu.

(3) Tipo 3 (Bastos 2001:59)

a. Com efeito-mas

Vender livro, eu tinha um amigo que vendia (mas...)

Fazer brigadeiro, eu conheço uma doceira que faz (mas...)

b. Sem efeito-mas

Vender livro, eu tinha um amigo que vendia [Foco de porta em porta]

Fazer brigadeiro, eu conheço uma doceira que faz [Foco todos os dias]

Segundo Bastos, o efeito-mas decorre de uma implicatura conversacional, termo de Grice (1975), que é uma violação das Máximas Conversacionais, mostradas em (4) abaixo. Grice propôs as Máximas Conversacionais, baseado no Principio de Cooperação, o qual estabelece que todos os diálogos são esforços cooperativos com um propósito comum entre os participantes; ou seja, ao nos comunicarmos, respeitamos essas Máximas com o intuito de colaborar com o diálogo em andamento.

(4) Grice (1975:45-46)

1. Quantidade: Faça com que sua contribuição seja tão informativa quanto necessário (para o propósito corrente do intercâmbio);

2. Qualidade: Tente fazer com que sua contribuição seja verdadeira;

3. Relação: Seja relevante;

4. Maneira: Seja claro, seja breve.

Dessa forma, para dar conta do cancelamento do efeito-mas quando há um elemento focalizado dentro de sentenças do tipo 2, Bastos assume que foco é um termo essencial para a estrutura da asserção e a informação associada a essas sentenças. Assim, quando o falante não focaliza um elemento dentro da sentença, ele está abandonando a Máxima de Quantidade, não dando todas as informações necessárias. Não fornecendo todas as informações necessárias, surge uma implicatura conversacional, denominada por Bastos de Implicatura Focal ou de Informatividade, definida em (5) abaixo. 
(5) Implicatura Focal ou de Informatividade (Bastos 2001:63)

Há uma informação relevante não-pressuposta, relacionada ao evento em questão, que foi implicitada.

Da violação da Máxima de Quantidade surge a Implicatura definida em (5) e é gerado o efeito-mas.

Entretanto, Vicente (2007), utilizando sentenças do espanhol, como as em (6) abaixo, sugere que o efeito-mas proposto por Bastos não decorreria da Máxima de Quantidade, mas sim da Máxima de Maneira, já que o falante poderia responder apenas com sim/não mas prefere fazer uma resposta completa, deixando implícito que há algo mais a ser dito.

(6) Vicente (2007: 67)

a. ¿Compró Juan las rosas? bought..3SG $\mathrm{J}$ the roses

"Did Juan buy the roses?"

b. Juan (no) compró las rosas (pero...) $\mathrm{J}$ not bought.3SG the roses but "Juan did (not) buy the roses (but still...)"

c. Sí / no yes no

Quanto à distribuição complementar com foco, Vicente alega que, quando há presença de foco, a sentença inteira não equivale mais a sim ou não, significando algo a mais. Assim, a implicatura associada com a sentença inteira desaparece (Vicente 2007: $68)$.

Portanto, a previsão da análise de Vicente (2007) é que toda vez que o falante pode responder sim/não mas opta por fazer uma sentença completa, violando a Máxima de Maneira, o efeito-mas é gerado. Por outro lado, a previsão de Bastos (2001)/ BastosGee (2009) é que, quando o foco na sentença é omitido, violando a Máxima de Quantidade, o efeito-mas é gerado. De posse dessas previsões, vamos analisar o cancelamento do efeito-mas nas estruturas com que-reportativo na seção a seguir. 


\subsection{Cancelamento do efeito-mas nas construções com que-reportativo}

As estruturas com que-reportativo apresentam o efeito-mas, como visto na seção 2.2.1.2 e exemplificado por (7) abaixo.

(7) a. QC: O Pedro vende verduras mais barato?

R: Que ele vende mais barato, ele vende (mas as verduras são velhas).

b. QC: A Maria saiu com o cachorro pra passear?

R: Que ela saiu com o cachorro, ela saiu (mas...)

Além disso, as estruturas com que-reportativo apresentam ausência de foco, já que essas construções não são compatíveis com elementos focalizados, como vemos em (8) abaixo.

(8) a. QC: Quando o João vendeu a casa?

R: \#Que ele vendeu a casa, ele vendeu [Foco ontem].

b. QC: Onde o João vendeu a casa?

R: \#Que ele vendeu a casa, ele vendeu [Foco na internet]

c. QC: O João alugou a casa?

R: \#Que ele [Foco vendeu o apartamento], ele vendeu.

Há dois casos em que o efeito-mas não é obrigatório nas construções com quereportativo: o primeiro caso é quando inserimos uma sentença encaixada de verbos epistêmicos com sujeito em primeira pessoa, como vemos no contraste entre (9) e (10) abaixo.

(9) a. QC: O João também conserta celular?

R: Que ele conserta celular, eu acho/penso/acredito que ele conserta.

b. QC: A Maria limpou a casa como eu pedi?

R: Que ela limpou a casa, eu acho/penso/acredito que ela limpou.

c. QC: O Pedro fez a lição?

R: Que ele fez a lição, eu acho/penso/acredito que ele fez. 
(10) a. QC: O João comeu o bolo?

R: Que ele comeu o bolo, a Maria acha que ele comeu (mas...)

b. QC: A Maria leu o livro que eu recomendei?

R: Que ela leu o livro, o Pedro acredita que ela leu (mas...)

c. QC: O Pedro comeu a torta que eu fiz?

R: Que ele comeu a torta, a Maria pensa que ele comeu (mas...)

O segundo caso é quando inserimos um constituinte de confirmação no meio da sentença, como apontado por Esmeralda Negrão (comunicação pessoal) (ver (11a) abaixo) ou no fim, como observado por Janayna Carvalho (comunicação pessoal) (ver (11b) e (11c) abaixo).

(11) QC: O João também conserta celular?

a. Que ele conserta celular, sim, ele conserta.

b. Que ele conserta celular, ele conserta, sim.

c. Que ele conserta celular, não, ele não conserta.

d. Que ele concerta celular, ele não conserta, não.

Porém, os exemplos em (11) acima parecem expressar características diferentes do caráter reportativo das construções com que-reportativo. O que temos em sentenças como (11) acima são características de hesitação por parte do falante, ou seja, as expressões iniciadas por que são na verdade a repetição da questão contextualizadora com o objetivo do falante ponderar a confirmação da questão.

Uma evidência de que as sentenças em (11) não são estruturas com quereportativo é que a repetição verbal nessas estruturas não precisa ser idêntica, o que é impossível nas estruturas com que-reportativo, como vemos no contraste entre (12) e (13) abaixo.

(12) Que-reportativo

a. QC: O João também conserta celular?

$\mathrm{R}:{ }^{*}$ Que ele conserta celular, ele faz isso (mas...)

b. QC: A Maria limpou o apartamento como eu pedi? 
$\mathrm{R}$ : *Que ela limpou, ela fez isso (mas...)

c. QC: O Pedro falou com a coordenadora?

R: *Que ele falou, ele fez isso (mas...)

(13) QC: O João também conserta celular?

a. Que ele conserta celular, sim, ele faz isso há muito tempo.

b. Que ele conserta celular, ele faz isso, sim.

c. Que ele conserta celular, não, ele não faz isso.

d. Que ele concerta celular, ele não faz isso, não.

Outro teste é a presença de advérbios de atos de fala, que são possíveis em estruturas com que-reportativo, como vemos em (14) abaixo, mas não são possíveis nas estruturas em (11) acima, como mostra (15).

(14) a. QC: Você sabe se o João comeu o bolo?

R: Sinceramente, que ele comeu o bolo, ele comeu (mas fez careta o tempo todo)

b. QC: A Maria deve dinheiro pra empresa?

R: Francamente, que ela deve dinheiro, ela deve (mas não tem como pagar)

c. QC: O João fez a lição de casa?

R: Sinceramente, que ele fez a lição de casa, ele fez (mas não fez bem feito)

(15) QC: O João também conserta celular?

a. \#Sinceramente, que ele conserta celular, sim, ele conserta.

b. \#Francamente, que ele conserta celular, ele conserta, sim.

c. \#Sinceramente, que ele conserta celular, não, ele não conserta.

d. \#Francamente, que ele concerta celular, ele não conserta, não.

Vemos pelos testes em (12)-(15) acima que as estruturas em (11) realmente não são estruturas com que-reportativo. Na próxima seção serão analisados os casos como (9) em que há cancelamento do efeito-mas nas estruturas com que-reportativo.

\subsection{A causa do cancelamento do efeito-mas nas estruturas com que-reportativo}


Minha proposta é que o cancelamento do efeito-mas nas estruturas com quereportativo quando inserimos uma sentença encaixada que expressa dúvida ou percepção por parte do falante está relacionado também à Máxima de Quantidade. Isso se dá porque quando o falante expressa incerteza ou afirmação, o enunciado proferido é o máximo de informação necessária que o falante possui, ou seja, se o falante negasse ou afirmasse algo sobre que ele não tivesse certeza, ele estaria violando a Máxima de Qualidade. Assim, o informante está sendo cooperativo, respeitando todas as cinco máximas conversacionais e o efeito-mas não é desencadeado.

Em uma sentença com que-reportativo, como em (9a) repetida abaixo como (16), temos que o falante está respeitando todas as máximas, como vemos a interpretação em (17) abaixo, não gerando, portanto, nenhuma implicatura para produzir o efeito-mas.

(16) QC: O João também conserta celular?

R: Que ele conserta celular, eu acho/penso/acredito que ele conserta.

(17) Que ele conserta celular, eu acho/penso/acredito que ele conserta.

1. Se o falante tem dúvida, expressar a dúvida é o máximo de informação necessária que ele possui para satisfazer 2;

2. O falante está sendo verdadeiro;

3. O falante está sendo relevante;

4. O falante está se expressando de modo claro.

A proposta de Vicente (2007), vista na seção 5.1 acima, não daria conta desses casos de cancelamento do efeito-mas em estruturas com que-reportativos porque a proposta se concentra na estrutura da sentença em si. Como apresentado em 5.1, Vicente propõe que se o falante opta por usar uma sentença completa ao invés de responder sim/não, o efeito-mas seria desencadeado porque a sentença completa indica que há informações implícitas. Os casos das estruturas com que-reportativo, porém, são casos que envolvem o conteúdo das sentenças e não a estrutura curta ou completa, já que se o falante responder $\operatorname{sim} / n \tilde{a} o$ não tendo certeza da informação dada, ele estaria violando a Máxima de Qualidade. Assim, o falante poderia responder em casos de dúvidas e 
incertezas "não sei" ou "não tenho certeza" e, ao utilizar a sentença completa, o efeitomas seria desencadeado. Entretanto, as estruturas com que-reportativo continuam com o efeito-mas cancelado nos casos de sentenças encaixadas com verbos epistêmicos em primeira pessoa mesmo com o falante não optando por essas respostas curtas, o que mostra que a estrutura da sentença não é o que importa nesses casos, mas sim o máximo de informação que a sentença veicula.

Se essa proposta de o cancelamento do efeito-mas estar relacionado ao máximo de informação que o falante possui estiver no caminho certo, a previsão que se faz é que as construções de topicalização de infinitivos do tipo 2 de Bastos devem perder a obrigatoriedade do efeito-mas quando se insere uma sentença encaixada de verbos epistêmicos em primeira pessoa. Os dados em (18) abaixo confirmam a previsão, já que o efeito-mas não é obrigatório nesses casos.

(18) a. QC: O João lavou o carro?

R: Lavar o carro, eu acho/penso/acredito que ele lavou.

b. QC: A Maria limpou a casa como eu pedi?

$\mathrm{R}$ : Limpar a casa, eu acho/penso/acredito que ela limpou.

c. QC: O Pedro arquivou aquela tese?

$\mathrm{R}$ : Arquivar aquela tese, eu acho/penso/acredito que ele arquivou.

As sentenças em (18) acima reforçam a proposta de que o cancelamento do efeito-mas está relacionado à quantidade de informação necessária que o falante possui ao proferir um enunciado. Se colocarmos a sentença encaixada em terceira pessoa, vemos que o efeito-mas se torna obrigatório novamente, como em (19) abaixo.

(19) a. QC: O João lavou o carro?

R: Lavar o carro, a Maria acha que ele lavou (mas...)

b. QC: A Maria limpou a casa como eu pedi?

R: Limpar a casa, o Pedro acredita que ela limpou (mas...)

c. QC: O Pedro arquivou aquela tese?

R: Arquivar aquela tese, a Maria pensa que ele arquivou (mas...) 
Vemos em (19) acima que, ao utilizar uma sentença encaixada de verbos epistêmicos com sujeito em terceira pessoa, temos a sensação que o falante não está dando o máximo de informação, pois ao dizer que alguém "acha" ou "pensa" o falante parece insinuar que esse alguém não sabe a verdade. Exemplos como em (20) abaixo ilustram essa sensação de incompletude.

(20) a. QC: O João lavou o carro?

R: Lavar o carro, a Maria acha que ele lavou, mas na verdade ele não lavou.

b. QC: A Maria limpou a casa como eu pedi?

R: Limpar a casa, o Pedro acredita que ela limpou, mas na verdade ela só varreu.

c. QC: O Pedro arquivou aquela tese?

R: Arquivar aquela tese, a Maria pensa que ele arquivou, mas ele ainda não teve tempo.

Vemos que a manutenção do efeito-mas em sentenças encaixadas de verbos epistêmicos com sujeito em terceira pessoa evidencia que o cancelamento do efeito-mas não está relacionado com a opção do falante em utilizar uma estrutura longa, mas com o máximo de informação que o falante possui, já que encaixadas de verbos epistêmicos com sujeitos em terceira pessoa deixam a sensação de incompletude da informação dada pelo falante.

Outra evidência de que o efeito-mas é cancelado quando o máximo de informação se torna evidente são sentenças como em (21) abaixo que, ao inserir uma coordenada aditiva que evidencia mais informações que o falante possui, o efeito-mas também é cancelado.

(21) QC: O João conserta celular?

a. Que ele conserta celular, ele conserta e muito bem por sinal!

b. Que ele conserta celular, ele conserta e bem consertado!

c. Que ele conserta celular, ele conserta e o preço é camarada! 
Vemos em (21) acima que as estruturas com que-reportativo com uma coordenada aditiva não desencadeiam o efeito-mas pois a coordenada adicional mostra o máximo de informação que o falante possui. Ao inserir uma coordenada aditiva nas estruturas de infinitivos topicalizados, temos que o efeito-mas também não é desencadeado, como mostra (22).

(22) a. QC: O João lavou o carro?

R: Lavar o carro, ele lavou, e muito bem por sinal!

b. QC: A Maria limpou a casa como eu pedi?

R: Limpar a casa, ela limpou e bem limpado!

c. QC: O Pedro arquivou aquela tese?

$\mathrm{R}$ : Arquivar aquela tese, ele arquivou e rapidinho!

Assim, vemos que o máximo de informação é o que causa o cancelamento do efeito-mas.

\subsection{A possibilidade de outros itens lexicais com efeito-mas}

Vimos na seção 2.2.1.4 que o efeito-mas pode ocorrer com outros itens lexicais, como só e já. O interessante é que esses itens estão em distribuição complementar, como vemos em (23) abaixo.

(23) a. QC: O João não disse que vai comer esse bolo?

R: Que ele vai comer, ele vai, só/mas/*já não disse quando.

b. QC: Você fez a sobremesa para amanhã?

R: Que eu fiz, eu fiz, só/mas/*já não aquela que você pediu.

c. QC: O João vai pro casamento?

R: Que ele vai, ele vai, já/mas/*só a esposa dele eu não sei.

d. QC: Vai ter prova escrita e oral amanhã?

R: Que vai ter prova escrita, vai, já/mas/*só prova oral eu não tenho certeza.

A distribuição complementar pode ser explicada se assumirmos a análise de Lacerda (em preparação), segundo a qual o item já é associado a um DP, ou seja, a itens 
nominais, enquanto só pode também se associar a CPs. Isso é confirmado pelo fato de só aceitar um complementizador, enquanto já não aceita como vemos em (24) abaixo ${ }^{12}$.

(24) a. QC: O João não disse que vai comer esse bolo?

R: Que ele vai comer, ele vai, só (que) não disse quando.

b. QC: Você fez a sobremesa para amanhã?

R: Que eu fiz, eu fiz só (que) não aquela que você pediu.

c. QC: O João vai pro casamento?

R: Que ele vai, ele vai, já (*que) a esposa dele eu não sei.

d. QC: Vai ter prova escrita e oral amanhã?

R: Que vai ter prova escrita, vai, já (*que) prova oral eu não tenho certeza.

\subsection{Conclusão}

Neste capítulo foi apresentado inicialmente como o efeito-mas e seu cancelamento são analisados nas propostas de Bastos (2001)/Bastos-Gee (2009) e Vicente (2007), como esquematizado abaixo:

- Para Bastos (2001)/Bastos-Gee (2009), a presença de foco é essencial para a sentença; assim, quando o falante omite a presença de foco, ele está violando a Máxima de Quantidade de Grice (1975) e, dessa violação, temos o efeito-mas;

- Para Vicente (2007), o efeito-mas surge da violação da Máxima de Maneira, já que o falante opta por fazer uso de uma estrutura longa ao invés de responder apenas sim/não, para deixar claro que há algo implícito.

\footnotetext{
12 Seguindo uma sugestão de Renato Lacerda (comunicação pessoal), estruturas clivadas, como em (i) abaixo, também mostram que estamos lidando com itens que se associam a constituintes diferentes.

(i) QC: Vai ter prova escrita e oral amanhã?

a. Que vai ter prova escrita, vai, *já/só a prova oral é que eu não tenho certeza.
} 
Após a apresentação das propostas, foi analisado como se dá o cancelamento do efeito-mas nas estruturas com que-reportativo quando temos uma encaixada de verbo epistêmico com sujeito em primeira pessoa do singular (ver (9) acima): estas estruturas têm o efeito-mas cancelado devido ao fato de já apresentarem o máximo de informação que o falante pode veicular, ou seja, o falante ao usar um verbo epistêmico em primeira pessoa está evidenciando que a dúvida ou pensamento é o máximo de informação que ele detém, pois ao afirmar ou negar algo de que ele não tem certeza, ele estaria violando a Máxima de Qualidade. Dessa forma, o efeito-mas está associado ao máximo de informação que o falante possui, surgindo, portanto, da violação da Máxima de Quantidade de Grice (1975). Essa análise é reforçada pelo fato de sentenças encaixadas com verbos epistêmicos em terceira pessoa desencadearem o efeito-mas (ver (20) acima), visto que um verbo epistêmico em terceira pessoa deixa em aberto a possibilidade de o falante possuir mais informações que quer deixar implícitas. Portanto, a análise do cancelamento do efeito-mas das estruturas com que-reportativo traz mais evidências para apoiar a análise de Bastos (2001)/Bastos-Gee (2009).

Outros tipos de estrutura, como as sentenças que apresentam um constituinte de confirmação, também foram analisadas, porém, não são estruturas com que-reportativo, pois essas sentenças com constituintes de confirmação expressam hesitação e não necessitam apresentar repetição verbal idêntica, característica fundamental das construções com que-reportativo.

Outro ponto analisado foi a possibilidade de outros itens lexicais, como só e já, nas orações adversativas das estruturas com que-reportativo, possibilidade analisada como associação desses itens a diferentes constituintes, a saber itens nominais, no caso de já, e CPs no caso de só. 


\section{CONSIDERAÇÕES FINAIS}

Nesta dissertação, foram analisados dois tipos de construções com repetição verbal iniciadas por que: as construções com que-reportativo e as construções com queadversativo. A principal diferença entre elas é a posição do constituinte iniciado por que, pois em construções com que-reportativo, o constituinte está no primeiro bloco da construção enquanto em construções com que-adversativo, o constituinte está no segundo termo da construção.

No capítulo 1, as estruturas foram apresentadas, assim como as suas principais diferenças.

No decorrer do capítulo 2, estas construções foram comparadas com outras construções que possuem repetição verbal no português brasileiro (Bastos 2001/ BastosGee 2009) e no português europeu (Martins 2007), as quais têm suas repetições verbais derivadas por fusão morfológica (Nunes 2004). Nas comparações foi possível estabelecer que as estruturas com que-reportativo e que-adversativo não são derivadas por fusão morfológica, pois podem apresentar repetição verbal com constituintes morfologicamente mais complexos, como com negação ou com dois verbos. Um primeiro mapeamento das estruturas também foi possível, mostrando que estas têm a repetição verbal gerada por movimento, que as repetições verbais das estruturas precisam ser idênticas, não aceitando a pro-forma fazer isso, e que as estruturas com que-reportativo apresentam caráter reportativo obrigatório.

No capítulo 3, as estruturas com que-reportativo e que-adversativo foram comparadas entre si considerando questões de identidade, mostrando as características semelhantes e diferentes que elas apresentam. O foco da comparação foi entre identidade dos verbos do contexto e as ocorrências verbais das estruturas e vimos que ambas as estruturas necessitam de que suas ocorrências verbais sejam idênticas. Em relação ao contexto, as estruturas com que-reportativo são sensíveis aos verbos do contexto, enquanto as estruturas com que-adversativo não são. Três aparentes contraexemplos foram analisados: o caso do presente histórico, o caso do modo subjuntivo e as respostas negativas. As construções com que-reportativo no presente histórico não repetem a mesma morfossintaxe dos verbos contextuais, porém, vimos que se trata de uma restrição pragmática do próprio presente histórico. No caso do subjuntivo, as 
ocorrências verbais, na presença de um advérbio como talvez, não precisam ser idênticas. Entretanto, sob análise mais cuidadosa, vimos que esses casos não são de fato estruturas com que-reportativo e que-adversativo, mas estruturas de hesitação. O último caso das respostas negativas, em que a negação nas estruturas com que-reportativo não aparecem no mesmo local das negações do contexto, vimos que são casos de alçamento de negação, ou seja, as estruturas com que-reportativo recuperam a posição original da negação, não violando identidade.

No capítulo 4, foi analisada a estrutura informacional dos blocos das estruturas com que-reportativo e que-adversativo. Os testes para foco (Zubizarreta 1998) mostraram que tanto as construções com que-reportativo quanto às construções com que-adversativo não apresentam foco apresentacional nem foco contrastivo nos termos iniciados por que das estruturas. Esses blocos apresentam características de tópicos (Rizzi 1997), como estar mais à esquerda e ser separado por entoação de vírgula. A característica de apresentar informação velha só é vista nas estruturas com quereportativo, caracterizando-as como compostas por um tópico conversacional. Já as estruturas com que-adversativo, por não serem dependentes do contexto, podem apresentar informação nova. Porém, vimos na análise proposta que a informação nova destas estruturas é selecionada de um subconjunto de possíveis respostas a subperguntas pragmaticamente relacionadas à pergunta em discussão (Büring 2000; Lee 2003), o que classifica esse bloco como um tópico contrastivo. Através de testes de movimento, como orações coordenadas e orações adjunto, vimos que esses tópicos são derivados por movimento, mas a posição de origem desses tópicos foi deixada para pesquisas futuras. Os testes com orações relativas foram descartados, pois sob análise mais cuidadosa, demonstraram não serem estruturas com que-reportativo e que-adversativo, por aceitarem a pro-forma fazer isso e não aceitarem advérbios de atos de fala, os quais são aceitos pelas estruturas com que-reportativo e que-adversativo.

No capítulo 5, o cancelamento do efeito-mas nas construções com quereportativo quando temos uma encaixada de verbo epistêmico em primeira pessoa foi analisado como possível devido ao falante já estar proferindo o máximo de informação que possui. Essa hipótese é reforçada por as estruturas de infinitivo topicalizado de Bastos (2001)/ Bastos-Gee (2009) também não desencadearem o efeito-mas na presença de encaixadas com verbo epistêmico. Assim, o cancelamento do efeito-mas nas 
estruturas com que-reportativo também está relacionado à Máxima de Quantidade de Grice (1875), apoiando a análise de Bastos (2001)/ Bastos-Gee (2009).

Como foi visto nesta dissertação, as construções com que-reportativo e queadversativo, aparentemente similares a outras construções com repetição verbal, possuem características muito particulares e são compostas por diferentes tópicos, a saber, tópico conversacional e tópico contrastivo, como foi explorado nesta pesquisa. 


\section{REFERÊNCIAS BIBLIOGRÁFICAS}

BASTOS, A. C. Fazer, eu faço! Topicalização de projeções verbais em Português Brasileiro. Dissertação de Mestrado, Universidade de Campinas, 2001.

BASTOS-GEE, A. C. "Topicalization of verbal projections in Brazilian Portuguese". In: NUNES, Jairo (Ed.), Minimalist Essays on Brazilian Portuguese Syntax, John Benjamins Publishing Company, 2009.

BELLETTI, A. "Aspects of the low IP area". In: L. Rizzi (ed.), The Structure of CP and IP. The Cartography of Syntactic Structures, Vol.2. New York: Oxford University Press, pp.16-51, 2004.

BIANCHI, V. \& FRASCARELLI, M. “Is topic a root phenomenon?” In: Iberia, vol 2.1, pp. 43-88, 2010.

BÜRING, D. "On D-trees, beans, and B-Accents”. In: Linguistics and Philosophy 26, pp.511-545, 2000.

CHOMSKY, N. The minimalist program. The MIT Press, Cambridge, MA, 1995.

CYRINO, S.M.L. O Objeto nulo no Português do Brasil: um estudo sintáticodiacrônico. Tese (Doutorado em Linguística) Campinas, SP: UNICAMP, 1994.

FERREIRA, M. Argumentos nulos em português brasileiro. Tese de Mestrado, Universidade Estadual de Campinas, 2000.

FILLMORE, C. J."The position of embedding transformations in a grammar". In: Word 19: 208-31, 1963.

FRAJZYNGIER, Z. "Non-propositional addressees". In: Bradley Music, Randolph Graczyk, \& Caroline Wiltshire (Eds.), Papers from the 25th Annual Regional Meeting of the Chicago Linguistic Society, pp. 41-49, 1989.

FRASCARELLI, M. The Syntax-Phonology Interface in Focus and Topic Constructions in Italian. Netherlands: Kluwer Academic Publishers, 2000.

FRASCARELLI, M. \& HINTERHÖLZL, R. "Types of Topics in German and Italian", In: S. Winkler and K. Schwabe (eds.), On Information Structure, Meaning and Form, John Benjamins, Amsterdam/ Philadelphia, pp. 87-116, 2007.

GALVES, C. O objeto nulo no português brasileiro: percurso de uma pesquisa. Cadernos de Estudos Linguísticos 17: PP. 65-90, 1989. 
GRICE, H. P. "Logic and conversation". In: Syntax and Semantics. (P. Cole and J. L. Morgan.) v.3. pp. 41-58. Academic Press, New York, NY, 1975.

HALLE, M. \& A. MARANTZ. Distributed morphology and the pieces of Inflection. The MIT Press, Cambridge, MA, 1993.

KATO, M. A. The distribution of pronouns and null elements in object position in Brazilian Portuguese. In: Linguistic Perspectives on the Romance Languages, ed. By William J. Ashby, Marianne Mithun, Giorgio Perissinotto \& Eduardo Raposo, Amsterdam/Phladelphia: John Benjamins, pp. 225-235, 1993.

KAYNE, R. S. The Antisymmetry of Syntax. The MIT Press, Cambridge, MA, 1994.

KLOOSTER, W. "Negative raising revisited". In: Germania et Alia. A Linguistic Webschrift for 54 Hans den Besten. Jan Koster and Henk van Riemsdijk (eds.), 2003.

LACERDA, R. "Asymmetries between high and low topics in Brazilian Portuguese". General examination paper, University of Connecticut, 2015.

LAKA I., 1990. Negation in syntax: On the nature of functional categories and projections. PhD Dissertation, MIT, 1990.

LEE, C. "Contrastive topic and/or contrastive focus". In: Japanese/Korean linguistics, ed. William McClure. Vol. 12 of Center for the study of language and information. Stanford: CSLI, 2003.

MARTINS, A. M. "Double realization of verbal copies in European Portuguese emphatic affirmation". In: CORVER, Norbert; NUNES, Jairo (Ed.), The copy theory of movement. John Benjamins Publishing Company, 2007.

MUNN, A. Topics in the syntax and semantics of coordinate structures. Doctoral dissertation, University of Maryland, College Park, 1993.

NEGRÃO, E. V. "Wh-extraction and relative clauses in Brazilian Portuguese". In: DELTA, v. 16 N $^{\circ}$ Especial, pp. 141-163, 2000.

NUNES, J. “Sideward movement”. In: Linguistic Inquiry 32, 2001.

NUNES, J. Linearization of Chains and Sideward Movement. The MIT Press, Cambridge, MA, 2004. 
NUNES, J. "The Copy Theory". In C. Boeckx (org.): The Oxford Handbook of Linguistic Minimalism., 143-172. Oxford University Press, 2011.

NUNES, J. \& BOŠKOVIĆ, Z. "The copy theory of movement: A view from PF”. In: CORVER, Norbert; NUNES, Jairo (Ed.), The copy theory of movement. John Benjamins Publishing Company, 2007.

PETERSEN, M. C. O licenciamento do sujeito nulo em orações subjuntivas do PB: contribuições para a Teoria de Controle por Movimento. Universidade de São Paulo, dissertação de Mestrado, 2011.

RIZZI, L. "The fine structure of left periphery". In: Elements of Grammar (L. Haegeman, ed.), pp. 281-337. Kluwer, Dordrecht, Ginn and Company, 1997.

RODRIGUES, C. "Impoverished morphology and A-movement out of Case domains". Tese de doutorado, University of Maryland, College Park, 2004

$\mathrm{SAAB}, \mathrm{A}$. "Ineffable narratives in Spanish: Another case of overgeneration by $e$ GIVEness". In Probus, 2014.

VICENTE, L. The syntax of heads and phrases - A study of verb (phrase) fronting. PhD dissertation, Leiden University, 2007.

ZANUTTINI, R. "Re-examining negative clauses". In: Paths towards universal grammar: Studies in honor of Richard Kayne, CINQUE, G., KOSTER, J., POLLOCK, J., RIZZI, L. \& ZANUTTINI, R. (eds), Washington DC: Georgetown University Press, pp. 427-451, 1994.

ZANUTTINI, R. Negation and clausal structure: A comparative study of Romance languages. Oxford: OUP, 1997.

ZUBIZARRETA, M. L. Prosody, Focus and Word Order. Massachussetts: MIT Press, 1998. 